\title{
Alfonso X en Cádiz. Visión constitucional de un monarca del Medievo (II)
}

\section{Alfonso the $X^{\text {th }}$ in Cadix. Constitutional vision of a monarch from the Middle Ages (II)}

\author{
Faustino MARTÍNEZ MARTÍNEZ \\ Profesor Titular de Historia del Derecho \\ Departamento de Historia del Derecho \\ Instituto de Metodología e Historia de la Ciencia Jurídica \\ Facultad de Derecho. Universidad Complutense de Madrid \\ fmartine@der.ucm.es
}

Para Amalia, también y por supuesto

Recibido: 7 de mayo de 2012

Aceptado: 29 de junio de 2012

\section{RESUMEN}

Se analiza en esta segunda parte el papel que juegan Alfonso X y su obra legislativa como modelo político y modelo jurídico, tanto en el siglo XVIII como en los inicios del siglo XIX, con el escenario de las Cortes gaditanas y de la final Constitución allí aprobada. Historiadores y juristas usan a esta figura legendaria como fondo argumental para sostener posiciones políticas de todo signo y para justificar decisiones jurídicas.

PALABRAS CLAVE: Alfonso X, Leyes Fundamentales, Constitución, Cortes de Cádiz, 1812. Medievalismo, Historicismo.

\begin{abstract}
This second part discusses the role of Alfonso $\mathrm{X}$ and his legislative work as a political model as well as a legal model in the $18^{\text {th }}$ century and in the early $19^{\text {th }}$ century, whithin the Cadiz Cortes and the Constitution which was approved there. This legendary figure is used by historians and jurists as a background argument to support political positions of every orientation, as well to justify legal decisions .
\end{abstract}

KEYWORDS: Alfonso X of Castile, Fundamental Laws, Constitution, Cadiz Cortes, 1812, Medievalism, Historicism.

\section{RÉSUMÉ}

Dans cette seconde partie on aborde le rôle d'Alphonse $X$ et son oeuvre comme modèle politique et juridique, utilisé dans le XVIII ${ }^{\mathrm{e}}$ siècle et au début du $\mathrm{XIX}^{\mathrm{e}}$ siècle dans le scénario des Cortes de Cadix et dans la Constitution qui y a été finalement approuvée. Les historiens et les juristes auraient utilisé cette figure légendaire comme une argument de fond pour soutenir positions politiques de tous les signes, ainsi que pour justifier des décisions juridiques.

MOTS CLÉ : Alphonse X de Castile, Lois Fondamentales, Constitution, Cortes de Cadix, 1812, Médievalisme. Historicisme. 


\section{ZUSAMMENFASSUNG}

In diesem zweiten Teil des Beitrages geht es um die Rolle, die Alfons X. und sein Gesetzeswerk als politisches und juristisches Modell sowohl im 18. als auch zu Beginn des 19. Jahrhunderts gespielt haben. Historiker wie Juristen verwenden die legendäre Figur des Monarchen als Argumentationsfundus, um politische Positionen aller Art zu rechtfertigen und um rechtliche Entscheidungen zu begründen.

SCHLÜSSELWÖRTER: Alfons X, Grundrechte, Verfassung, Ständeversammlungen (Cortes) von Cádiz, 1812, Mediävistik, Historizismus.

1. Como se ha podido desarrollar en la primera parte de este trabajo, frente a la rotundidad de caracteres, la entereza y la personalidad de épocas anteriores, muy especialmente, los dos siglos previos, el XVIII se presenta, por el contrario, ante nuestros ojos como un siglo nada claro y definido en cuanto a sus perfiles esenciales, muy difícil de radiografiar con sencillez, pero sin llegar a ser oscuro y remoto, pleno de contradicciones motivadas por la presencia agonística de agentes exógenos y endógenos de signo contrario, cuando no adverso; es un tiempo de avances y de retrocesos prácticamente continuos y sin cuartel. El Siglo de las Luces, el de la Ilustración, parece deslumbrarnos haciendo honor a su nombre y nos impide penetrar en su más puro sentido interno. Los dos anteriores nos conducen a un escenario de construcción, consolidación y decadencia de la Monarquía Hispánica universal, pero el XVIII es mucho más enigmático y controvertido. Se perfila, por tanto, para los historiadores como un siglo de luchas entre un ser hispánico sempiterno -o que creía y/o pretendía serlo-, y otro que intentaba aflorar por la vía de la reforma, no obstante los condicionantes contrarios que presidían su alumbramiento y la materialización de sus planes, es decir, es lucha constante entre deseos de cambio y realidades que se resisten a tales impulsos: la Ilustración reformista pugnó abiertamente con los elementos previos renuentes a toda modificación y con las inercias de muchos siglos profundamente instaladas, pero también con una Ilustración radical o liberal, que solamente aflora a finales del siglo en un contexto que nada o muy poco tiene que ver con los momentos iniciales que cimentan ese nuevo tiempo histórico ${ }^{1}$. Fue un siglo reformista, no revolucionario, que se movió dentro de los cauces estrictos que marcaba el orden estamental al que no se pudo combatir de ninguna de las maneras posibles. Reformas hubo, pero pergeñadas dentro de los límites que indicaba toda una serie de condicio-

\footnotetext{
${ }^{1}$ Vid. F. Aguilar Piñal, La España del Absolutismo Ilustrado. Madrid, 2005; A. Domínguez Ortiz, Carlos III y la España de la Ilustración. Madrid, 2005; y F. Sánchez-Blanco, La Ilustración en España. Madrid, 1997; y La Ilustración goyesca. La cultura en España durante el reinado de Carlos IV (1788-1808). Madrid, 2007. Ahora también, vid. L. M. Enciso Recio, Compases finales de la cultura ilustrada en la época de Carlos IV. Madrid, 2013; T. A Mantecón, España en tiempos de Ilustración. Los desafíos del siglo XVIII. Madrid, 2013; y AA. VV., Hacia 1812 desde el Siglo Ilustrado. Actas del V Congreso Internacional de la Sociedad Española de Estudios del Siglo XVIII. Edición coordinada por Fernando Durán López. Gijón, 2013.
} 
nantes previos, políticos, sociales y religiosos, los cuales hicieron de todo punto imposible el cambio real, rotundo y absoluto: gremios, corporaciones, estamentos, etc., conformaron unos valladares insuperables para la acción política hasta el punto de condicionar sus resultados finales. El reformismo, ligado al absolutismo, tuvo que comprender que la única manera de articularse era precisamente aceptando esos presupuestos de partida que se le ofrecían, esos caminos ya trazados. Reformar, pero dentro de un orden dado, dentro de un marco previo inmodificable e intocable, sin que pudiese aflorar una voluntad constituyente nítida, fundadora de un orden nuevo, sino simplemente una reconstituyente, lo que implicaba aceptar muchos presupuestos políticos y sociales que no podían ser cuestionados en lo más mínimo, que tenían que ser aceptados como auténticos dogmas de fe porque en ellos estaba la sustancia misma de la sociedad a la que iban dirigidos aquellos cambios ${ }^{2}$.

En este dilema o en esta dicotomía (continuidad versus reforma), está cifrado a modo de resumen o compendio el Siglo de las Luces hispánico, una centuria en la que precisamente por todo lo anterior, por esa lucha entre pasado y presente, entre inmovilidad y cambio, para alzarse con el futuro, España comienza a interesarse por sí misma y por su Historia, y comienza también a contemplar a Europa como una posible solución a los males que la aquejaban: se actúa a partir del legado amplio de los conocimientos que suministran historiadores de todo signo. Siglo, por tanto, europeísta e historicista, al mismo tiempo. Apologistas y críticos pueblan bibliotecas, librerías e imprentas con sus escritos destinados, en el primer caso, a poner de manifiesto lo mucho que la civilización debía a España, no obstante las crisis que se estaban padeciendo en estos lares, a magnificar la indiscutible herencia procedente de estas tierras, o bien, en el segundo de los ejemplos, a poner de relieve la insatisfacción de lo pretérito y la necesidad de aferrarse a Europa como elemento cultural de primera magnitud, único capaz de remover el marasmo intelectual patrio (responsabilizándose así de convertir a España en caja de resonancia del pensamiento europeo, sin perjuicio de que el marco religioso y el marco político constituyeran siempre dos límites insoslayables por parte de cualquier persona que pensase en y sobre España a lo largo de esos años) $)^{3}$. Es un siglo de Historia, pero también es un siglo crítico y de decidido cuestionamiento de ese conocimiento que se venía cultivando, dando lugar así a una Historia abierta, revisable, opinable. Es tiempo en el que España se enfrenta a sí misma, a sus propios destinos, pasados, presentes y, por añadidura, no paran de surgir contradicciones y contrasentidos; deviene así un tiempo de introspección y de autorreflexión críticas que acaba desembocando en un culto, en una pasión desbordante por la Historia, modelo y ejemplo al que hay que acudir para defender la patria o para

\footnotetext{
2 Vid. F. J. Guillamón Álvarez, Reformismo en los límites del orden estamental. De Saavedra Fajardo a Floridablanca. Murcia, 2010.

${ }^{3}$ Vid. F. Sánchez-Blanco, La mentalidad ilustrada. Madrid, 1999; A. Mestre Sanchís, Apología y crítica de España en el siglo XVIII. Madrid, 2003; y, del primero, recientemente, La Ilustración y la unidad cultural europea. Madrid, 2013.
} 
proponer su reforma. Con el fin de explicar lo que estaba sucediendo, se recurrió al caudal histórico y allí se pudieron contemplar aciertos y errores, verdades y falsedades, supersticiones y algunos dogmas, virtudes y vicios, esencias y corrupciones. La Historia era reputada como tarea científica, sólidamente racional, pero, en no menor medida, como un loable empeño patriótico, por ende, comprometidamente sentimental. Elemento de saber y de conocimiento, pero también elemento de poder y de defensa que apelaba al componente emocional colectivo. A ella se vuelve siempre, a la misma Historia nacional, en el sentido de pretender hallar en su relato una suerte de explicación y, a partir de ahí, de remedio a todos los males que asolaban a una sociedad y a un Estado desfallecientes o, mejor dicho, en pleno proceso de reconstrucción y de tránsito hacia mejores épocas. La Historia fue la tabla de salvación a la que se aferraron todos los pensadores del momento, sin exclusión: con aquélla, se contrarrestaron los impulsos reformistas procedentes de la Corte, siendo lo tradicional un instrumento poderoso para desbaratar, a modo de dique, cualquier iniciativa, por nimia que fuese, de cambio, de innovación, de modificación del panorama político, social, cultural o económico existente, al mismo tiempo que fue empleado por esos mismos reformadores como excusa o motivo que justificase sus acciones novedosas en el sentido de recuperar tractos interrumpidos por años de mal gobierno y de despotismo explícito, esto es, presentando la novedad como restauración y eliminando cualquier riesgo de fractura de corte revolucionario. La Historia servía tanto para justificar el inmovilismo (lo que era debía seguir siendo, tal y como había sido) como la metamorfosis (había que cambiar con el objeto de recuperar o restaurar elementos del pasado, ocultados tras ciertas anomalías históricas: la reforma no era, en puridad, hacia adelante, sino hacia atrás, hacia el mundo pretérito). Se volvió la vista al pasado como espejo en el cual encontrar ventajas e inconvenientes, puntos de apoyo y de rechazo, y a esto se entregaron tanto los apologistas, defensores de unas esencias patrias inmutables, pero corrompibles (y que así lo habían sido, aunque susceptibles de corrección), cuanto los críticos, orientados a una superación del momento conocido, para recuperar pasados ideales o idealizados, con el fin de mejorar con algunos ajustes un modelo que podía seguir funcionando correctamente durante mucho tiempo. Se combatía con la Historia en la mano, blandiéndola como arma arrojadiza presta a ser enarbolada con el objeto de desbaratar los argumentos del rival de un modo pacífico. La lucha política se efectuaba en el escenario de la Historia con dos contendientes igual de preparados y de dispuestos a emplear los instrumentos del conocimiento a su exclusivo servicio para decantar la voluntad de quien tenía que tomar la decisión final.

Fue, sin ningún atisbo de duda, la gran protagonista de la centuria, pues con la Historia y sólo con ella se buscaba futuro a partir del pasado, se hacía Política premoderna, con todas sus ventajas, y sin necesidad de abrazar la temida, a la vez que ansiada, Modernidad, con todos los incontables riesgos de fractura y de ruptura que ésta traía consigo. Por eso, por esa situación de destino incierto que se vivía como resultado de la conmoción que inauguró el siglo (sucesión y cambio dinástico), la Historia era 
necesaria para conocer a la perfección el pasado y el presente y, con ellos dos, el ritmo y la dirección que había que tomar de inmediato. Era el asidero indispensable para todos los hombres públicos del momento, con los reyes a la cabeza. Para todo ello, se contó con un aliado de excepción que aseguró el triunfo de esta desatada pasión histórica e historiográfica. La ausencia de entronque nacional por parte de la nueva dinastía reinante, una familia de procedencia francesa que lo tenía todo (legitimidad, poder, títulos, soberanía en grado máximo, instrumentos de acción, deseos de renovación de los cuadros personales e institucionales, etc.), determinó un claro impulso para conseguir al precio que fuera necesario todo un arsenal de discursos que cubriesen ese flanco desprotegido de su autoridad, ese aspecto que no podía llenarse con otros componentes puramente políticos o económicos. La política cultural borbónica, con la fundación de Bibliotecas y Reales Academias (Real Biblioteca en 1712; Real Academia Española en 1713; Real Academia de la Historia, entre 1735 y 1738), con el control de las Universidades, y con la gestación de una erudición o intelectualidad cortesana de carácter oficial, debe ser leída en eso términos: crear una narración que insertase a los nuevos reyes en la tradición patria, dirigiendo y orientando los planteamientos culturales de la sociedad para hacer de ellos mismos sujetos indispensables del imaginario político. Diseñar y ejecutar, en fin, una Historia a su medida para imbricarlos en la realidad española de todos los tiempos y, desde allí, justificar sus decisiones políticas más relevantes y trascendentales para el momento concreto del que se tratase. De ahí, el férreo control del saber que se realizó desde las instancias cortesanas y desde los reductos educativos, oficiales u oficiosos, públicos o privados, cuando no el impulso decidido hacia una erudición nacional no sometida a debate, ni a discusión, nada neutral o pasiva, sino perfectamente incardinada en la dinámica expresada, generando de este modo una Ilustración total y maquinalmente manejada, dirigida y controlada por el poder político, es decir, una Ilustración oficial, sin disidencias reseñables, fuera de la que nada se podía encontrar ${ }^{4}$. Esto tuvo consecuencias, puesto que dio a ese movimiento hispánico un perfil conservador, en el sentido de reforzamiento de algunas de las elites existentes, de forma no deliberada, no obstante el impulso emancipador que tal movimiento traía consigo, y en el sentido de condicionar desarrollos y evoluciones a la (a una cierta) contemplación del pasado para obtener en buena medida su beneplácito y su convalidación: conservadora lo fue en sus orígenes y en sus conclusiones más directas esa Ilustración hispánica sin ningún tipo de dudas lo que diluye en buena medida el rasero kantiano de liberación y de cuestionamiento de la autoridad que singularizó, por contra, al homónimo movimiento europeo $^{5}$. Se acabó así por alejar cualquier suerte de radicalismo, lo que hizo que nuestro

\footnotetext{
${ }^{4}$ Vid. A. Calvo Maturana, Cuando manden los que obedecen. La clase politica e intelectual de la España preliberal (1780-1808). Madrid, 2013.

${ }^{5}$ Es el sentido que emplea J. G. A. Pocock, "Ilustración conservadora y revolución democrática: los casos de Norteamérica y Francia desde una perspectiva británica”, en Historia e Ilustración. Doce estudios. Edición de Antonio Feros y Julio A. Pardos. Traducción de A. Casado, X. Gil, J. A. Pardos,
} 
movimiento ilustrado no pudiera ser homologado al europeo, teñido de un componente más abierto, más liberal, más políticamente activo, como real anticipación de todo cuanto vendría después, es decir, como preludio de una auténtica revolución moderna que se encargaría de transformar tanto el Estado como la sociedad que se encontraba en su base. En España, por el contrario, faltaron los Denis Diderot y Paul Thiry D'Holbach que apadrinasen tal radicalismo y faltó el desarrollo ulterior de estos planteamientos bajo la forma de una revolución como inversión drástica de los esquemas políticos y sociales, que se quedó en simple reforma, más o menos amplia ${ }^{6}$. Asimismo el rigor científico, la búsqueda de libertad civil y política, la ruptura de los esquemas constrictivos del pasado y de sus fuentes de conocimiento, o la confianza en los medios críticos de la razón, incluso con la duda a la cabeza, tampoco llegan a florecer en estas tierras o, cuando menos, no de un modo generalizado ${ }^{7}$.

La Historia, así vertebrada y explicada, así oficializada, convertida en una suerte de discurso indiscutible públicamente respaldado, acabó por volverse, sin embargo, contra sus impulsores, puesto que se convirtió en el elemento más poderoso para contrarrestar las reformas que se animaron a realizar los diversos monarcas. Del mismo modo que fue un arma de ataque al orden estamental privilegiado, este mismo orden la empleó a modo de defensa con el resultado final de una parálisis enfermiza que a nadie benefició. Hubo, antes que triunfos épicos y cambios drásticos, célebres y sonados hundimientos; hubo proyectos, propuestas, bocetos, programas, antes que acciones y realidades concretas. La Historia neutralizó, por decirlo de algún modo, a sus mecenas y certificó el fracaso de muchas de sus aspiraciones e iniciativas de cambio. El conglomerado institucional y corporativo que formaba la máquina política subyacente contra la que se luchaba jugó así un doble papel: criticó los devaneos absolutistas de los monarcas, pero, al mismo tiempo, bloqueó cualquier posibilidad de reforma tanto del Estado como de los propios cuerpos intermedios. Ni dejó, por tanto, a los reyes maximizar su poder, ni tampoco toleró un reformismo con ansias de gran-

J. Pérez de Tudela, J. Pimentel y P. Sánchez. Madrid, 2002, pp. 287 ss. Como visiones complementarias, vid. T. Munck, Historia social de la Ilustración. Traducción castellana de Gonzalo G. Djembé. Barcelona, 2001; y J. M. Portillo Valdés, "Ilustración y Despotismo Ilustrado", en M. Artola (dir.) y J. A. Pardos Martínez (coord.), Historia de Europa. Madrid, 2007. Tomo I, pp. 239-296.

${ }^{6}$ Vid. J. I Israel, Radical Enlightenment. Philosophy and the Making of Modernity, 1650-1750. New York, 2001; y, del mismo, Enlightenment Contested. Philosophy, Modernity, and the Emancipation of Man, 1670-1752. New York, 2006; y P. Blom, Gente peligrosa. El radicalismo olvidado de la Ilustración europea. Traducción de Gabriel Najmías. Barcelona, 2012.

${ }^{7}$ Como ha expresado. F. Sánchez-Blanco, en La mentalidad ilustrada, ed. cit., pp. 332-333, "ilustrados" no fueron lo que tenían cierta cultura o criticaron el estado de cosas existente, sino quienes hicieron algo más perdurable y arriesgado: los que sometieron al análisis de la razón la realidad social sin doblegarse al dictado de la tradición, los que superaron el miedo a la autoridad y pensaron por sí mismos, y los que dejaron de reverenciar lo vigente y apoyaron proyectos fundados en argumentos de experiencia y de utilidad que afectaban a lo político y no se detuvieron ante ningún privilegio estamental. Y eso estaba en marcha ya a comienzos del siglo XVIII, pero no de una manera uniforme, ni con un alcance global. 
deza, libre y cuidado. F. Diaz lo expresó con suma claridad: España fue como un gran barco que, a pesar de los múltiples y generosos esfuerzos de su dotación, no consiguió emprender la navegación esperada, lo que dio como resultado un reformismo menudo, de perfiles económicos y técnicos, pero incapaz de meter mano en el aspecto institucional, administrativo, cultural o jurídico, territorios vedados y protegidos por siglos de privilegios y prerrogativas ${ }^{8}$. El reinado de Carlos III marcaría el punto de inflexión: en su tiempo, hay ya una clara preocupación por la política internacional, que consumirá esfuerzos y recursos, debilitando el frente interno, donde regalismo y catolicismo parecen ser marcas de la casa y por ese orden. La oposición de la Corte y de la sociedad se hace más evidente y el reformismo tiene que contentarse con mínimos retoques técnicos y económicos ${ }^{9}$, esencialmente estéticos, que no llegan al nervio principal, al conglomerado nuclear de donde todo partía, lo que provocará una cierta sensación de agotamiento y extenuación ante la evidente constatación de los fracasos cosechados una y otra vez ${ }^{10}$. Uno de los culpables de la ausencia de resultados reformistas tangibles fue ese renovado conocimiento histórico, convertido en arma de doble filo, de lo que se beneficiaron tanto los impulsores del cambio como los refractarios al mismo. Por todo lo expuesto, fue un siglo de plena y contundente efervescencia histórica e historiográfica y, por ende, también jurídica, dado que el Derecho seguía siendo la primera pieza indispensable para el conocimiento de la Historia y viceversa: la Historia nos mostraba un amplio fresco de textos jurídicos en vigor, sin importar edades, ni territorios, ni reyes autores o legisladores, ni, por último, procedencias. El Derecho era Historia puesto que solamente en la Historia podía aquél ser reconocido y conocido para su posterior comprensión. Pero también la Historia era Derecho, dado que no solamente enseñaba o ilustraba: la Historia imponía, mandaba, dictaba, ordenaba. Sus ejemplos eran más que sencillos apólogos con finalidad didáctica. Nos enseñaba no sólo cómo habíamos sido, sino también -y esto es lo más relevantecómo teníamos que seguir siendo en el futuro. Por descontado, Derecho e Historia eran las herramientas capitales para articular la serie de reformas que trataron de ser implementadas a lo largo de la centuria, puesto que ninguna de las dos había perdido

\footnotetext{
${ }^{8}$ Cfr. F. Díaz, Europa: de la Ilustración a la Revolución. Versión española de Carlo Caranci. Prólogo y capítulos I al VI de Lourdes Sanz Mingote. Madrid, 1994, pp. 495-496.

${ }^{9}$ Vid. F. Sánchez-Blanco, El Absolutismo y las Luces en el reinado de Carlos III. Madrid, 2002; y R. Torres Sánchez. El precio de la guerra. El Estado fiscal-militar de Carlos III (1779-1783). Madrid, 2013.

${ }^{10}$ Vid. J. I. Israel, Democratic Enlightenment. Philosophy, Revolution, and Human Rights, 1750-1790. New York, 2011, pp. 374 ss. Ante esa imposibilidad de alcanzar cambios de mayor calado, los objetivos a los que se dirige la acción pública serán, entre otros, el mundo colonial (donde se opera casi sin resistencia de ninguna clase), el crecimiento y la reorganización territoriales, la afirmación del poder regio (desde el punto de vista fáctico, jurídico y también simbólico), o la sola conservación del Estado en un contexto de ruina económica casi endémico (con la inestabilidad fiscal y los problemas generales de crecimiento), dinámica que es común a todos los reinos y principados europeos, con la sola excepción reseñable de la Toscana.
} 
ni un ápice de su coercibilidad como singular característica interna. El Derecho la presentaba desde siempre, pero la Historia se la había ganado. El Derecho era histórico puesto que allí, en tiempos remotos y no tanto, tenía su alojamiento natural, conservado como por arte de magia a lo largo de las centurias. Todo lo que una vez había sido Derecho, salvo muy puntuales excepciones, lo seguía siendo a la altura del siglo XVIII y estaba allí situado a disposición de la autoridad con independencia de los variados ropajes que lo cubriesen u ocultasen. Había que volver hacia ese conjunto de cuerpos variados donde se recogía la vida jurídica española desde hacia siglos.

Como se ha dicho, el Derecho no fue una excepción a esta tendencia retrospectiva, sino que el mundo jurídico se incardinó perfectamente en la tal línea política referida de un modo regular ${ }^{11}$ : el dilema se planteaba respecto a qué Derecho actuar u operar en ese retorno a las raíces o esencias, si el Común, de larga tradición que se retrotraía al Medievo sapiencial, o el racionalista, auspiciado por la Ilustración europea, dentro de la amplia gama de sistemas jurídicos a los que se podía recurrir en aquel entonces, sistemas plurales, abiertos, no finiquitados o ultimados, compuestos de múltiples piezas de dispar procedencia territorial y temporal, que solamente podían ser armonizados para casos particulares por la labor de los jurisprudentes, tanto teóricos como prácticos. Si aceptar el primero tenía sus inconvenientes, puesto que implicaba un cuestionamiento de la soberanía regia, el segundo era de todo punto imposible de asumir de acuerdo con las coordenadas intelectuales del siglo XVIII porque traía consigo una auténtica revolución en el sentido de una radical inversión del orden jurídico, político y social conocido, no obstante el proceso de depuración al que se somete desde instancias oficiales para hacerlo compatible lo más posible con los dogmas católicos imperantes. Si se seguía con la primera dirección, la del Derecho romano-canónico, se menoscababa el poder regio, en tanto en cuanto se depositaba en manos de un legislador ajeno y distante en el tiempo (mediatizado por la labor de los juristas intermedios) la articulación final del orden jurídico; si era la segunda la aceptada, se podría sostener aquella soberanía regia de modo incontestado, pero el escenario político y social sobre el que se proyectaría aquélla generaba numerosas dudas por su imprecisión, es decir, no se sabía exactamente sobre qué o sobre quiénes regiría ese Derecho presuntamente racional porque la sociedad sería de todo punto diferente ${ }^{12}$. Solamente quedaba una vía que armonizase ambos extremos (el poder del rey y la inmovilidad de la sociedad) y ésa era la histórica, es decir, la introspección que conducía a la recuperación del Derecho oculto u olvidado en el pasado más remoto y más reciente: había que proceder a la restauración y clarificación del Derecho pretérito que seguía siendo Derecho del presente, actual, vigente, ya que nada se derogaba

\footnotetext{
${ }^{11}$ Vid. S. Scandellari, Proposte di reforma legislativa nel secolo XVIII: la Spagna di Carlo III (Appunti e considerazioni). Sassari, 2001, pp. 89 ss.; y cfr. supra en Parte Primera, nota $\mathrm{n}^{\mathrm{o}} 23$.

${ }^{12}$ Vid. J. López Hernández, "La concepción del derecho en el pensamiento ilustrado", en E. Bello y A. Rivera (eds.), La Actitud Ilustrada. Valencia, 2002, pp. 85-119.
} 
o abrogaba en el universo conceptual del Derecho Común, que era el mundo ideológico dominante. Los beneficios de tal proceso eran inmediatos. De esta manera, quedaba salvaguardada la soberanía, puesto que el Derecho recuperado era el Derecho aprobado por los antiguos monarcas hispánicos, tomando como punto de partida la época visigoda, momento de primera y marcada independencia por parte de nuestro territorio respecto a dominaciones foráneas. No era Derecho ajeno o extraño, procedente de otras instancias políticas, de otros reyes o imperios, sino un Derecho creado por los reyes españoles en uso de la soberanía que los caracterizaba, con cierta participación de la sempiterna Nación española por medio de los Concilios y de las Cortes. Era, pues, Derecho soberano, no dependiente de otras instancias, auténtica y genuinamente español. Al mismo tiempo, era un Derecho tradicional, antiguo, revisitado o revivificado, por lo que no había riesgo de corromper el espíritu nacional, ni mucho menos: ese orden jurídico era típicamente hispánico en cuanto a sus orígenes y en cuanto a sus esencias. Y, como cuestión no menos relevante, no se fracturaba el orden social y político: quiénes creaban, recuperaban, regeneraban y recibían el Derecho, cada uno en su respectivo ámbito, seguían siendo los mismos sujetos de siempre, sin que se intercambiasen papeles o se invirtiesen roles en tal sentido. El Derecho anciano se aplicaría a los miembros de una sociedad que se quería y decía asimismo anciana, inmutable, no cambiante. Poder, tradición y orden social quedaban perfectamente conjugados, armonizados y asegurados por medio del recurso al Derecho nacional o patrio.

Del mismo modo que la afirmación político-monárquica pasaba por una vuelta histórica a los orígenes de la realeza, la afirmación jurídica de ésta implicaba un retorno a los textos primitivos, visigodos y medievales, donde estaba condensado ese sentimiento jurídico hispánico que debía singularizar el territorio sobre el que ahora gobernaban los Borbones. El trayecto a recorrer era hacia atrás, hacia el pasado, puesto que era en ese mundo ido donde se hallaban las esencias de aquel Derecho español que convenía recuperar en interés de todo el mundo, ya reyes, ya súbditos. Ése era el destino que marcaba la Historia y la ruta que debía ser recorrida imperativamente, sin interrupción posible, sin alteraciones de ninguna clase. Volviendo hacia el pasado se conseguía asegurar el presente y preparar el futuro. El Derecho de siempre era el que tenía que ser aplicado una y otra vez, sin pausa, ni excepción, con algunos matices bajo la forma de mejoras, correcciones o enmiendas, pero subsistiendo impoluto en sus líneas generales. El Auto Acordado, de 4 de diciembre de 1713, recordaba toda una larga travesía de incumplimientos que se intentaban finalizar infructuosamente, afirmando lo propio, lo patrio, lo nacional, como forma de reivindicar la soberanía de los reyes sin traicionar a la tradición de la que se formaba parte. Lo cierto es que por la vía del Derecho y de la Historia se volvía una y otra vez al Medievo y, por eso, los personajes del Medievo comparecía con rabiosa actualidad a modo de iconos cuyas palabras y testimonios tenían que ser escuchados. En ese Medievo se reconoció la forja de una vieja Constitución histórica, compendio o catálogo 
de Leyes Fundamentales, cuyo descubrimiento, actualización y aplicación va a constituir una obsesión a finales del siglo XVIII y comienzos del XIX, hasta el punto de marcar el debate político-jurídico casi con carácter exclusivo ${ }^{13}$.

2. En todo este recorrido sintetizado, ¿qué sitio queda para Alfonso X? ¿Qué suerte de recuerdo, de evocación, corresponde a un monarca cuyo protagonismo medieval es indiscutible? ¿Qué lugar queda para toda su sagrada obra legislativa, sólida, recuperada, vigente, mitificada, objeto de publicación en el siglo XVIII y en los inicios del siglo XIX como Derecho en vigor que era? Si su obra se va a emplear como parte de la columna vertebral de ese Derecho patrio redescubierto frente a los embates del Derecho Común, tendrá que ser imperativamente citado, recogido, recordado, tanto en lo que se refiere a su pensamiento como a su legado. Si se hace referencia continuada al Medievo, real o imaginado, a sus ensoñaciones, realidades, ideologías e instituciones, ¡qué menos que invocar a una monarca al que se atribuye, desde Jovellanos en adelante, una auténtica revolución constitucional en sus reinos! Con el Rey Sabio vamos a encontrarnos con una clara paradoja, representativa de esa dualidad intelectual que el hombre ilustrado protoliberal muestra acerca del modo de acercarse a su pasado, un pasado que no es aceptado en su totalidad, sino solamente a beneficio de inventario, de una forma muy selectiva y fragmentaria, en la medida en que servía a los propósitos basilares de la ideología imperante. Es cierto que a Alfonso X le debemos fundamentales textos normativos, plenamente vigentes en las centurias aludidas, textos capitales para rastrear y trazar una Historia de nuestro Derecho patrio o nacional, pero no es menos cierto que su reinado fue un tiempo conflictivo, con guerra civil incluida y con un problema sucesorio que se convierte en pugna jurídica de relevancia capital (se podría decir, sin temor a exagerar, que constitucional), dado que escenifica el choque entre el Derecho tradicional del reino, de corte nobiliario y señorial, y el nuevo Derecho que el rey trata de imponer por su sola voluntad, inspirado en la sapiencia de los juristas del Ius Commune, afirmando su autoridad y renovando el material jurídico de la Corona castellano-leonesa. Hay sabiduría jurídica incuestionable, pero no se puede soslayar el desastre político que el monarca dirigió a partir de algunas de sus decisiones en el campo del Derecho: enfrentamiento con sus herederos, luchas con la nobleza y las ciudades, espoleada precisamente por la aparición de alguno de sus textos normativos (caso del Fuero Real que postergaba la aplicación de buena parte de los fueros municipales castellanos y extremeños, erradicándolos en la práctica), textos fuertemente centralizadores en cuanto a la creación del Derecho y en cuanto a su aplicación, los nefastos efectos económicos de sus devaneos impe-

\footnotetext{
${ }^{13}$ Fundamental en este campo, como ya se ha tenido ocasión de manifestar, es J. M. Portillo Valdés, Revolución de Nación, ed. cit., passim, sintetizado, aunque con recorrido territorial más amplio, en la voz "Constitución" por él coordinada, en el Diccionario político y social del mundo iberoamericano. La era de las revoluciones, 1750-1850 [Iberconceptos - I]. Javier Fernández Sebastián (dir.). Madrid, 2009, pp. 305 ss.
} 
riales que sumen a los reinos en una crisis económica sin precedentes, etc. A modo de resumen global: un monarca sabio, prudente, bien intencionado, que, sin embargo fue un mal político, dubitativo, de tendencias autoritarias, que gobernó de espaldas al reino, que apenas convocó Cortes, es decir, que obvió buena parte de los elementos que integraban la Constitución histórica, tal y como se contemplaba desde la perspectiva de los siglos XVIII y XIX. Ni el debate, ni el consenso, ni la moderación, ni el equilibrio, pueden aplicarse al reinado caótico de Alfonso X, por lo que no era un buen modelo político a aplicar, ni a seguir, ni, por supuesto, a recuperar, al menos en su integridad. En resumidas cuentas, para con el Rey Sabio, se elabora una disyuntiva, una dualidad, una cierta esquizofrenia valorativa, que es la que afecta, por un lado, a su obra normativa, la cual, sin discusión, forma parte de aquellas Leyes Fundamentales, de aquella Constitución histórica, que desde tiempos inmemoriales rige la Monarquía Hispánica (la Constitución como legado jurídico del pasado, compuesto de múltiples y antiguas piezas, entre las que destacan por su peso específico el Fuero Real y las Partidas, amén de otras obras vinculadas al escritorio alfonsino como las Leyes del Estilo o el Espéculo), dignas de los mayores y mejores elogios, y, por otra, su modelo, prácticas y estilos políticos, absolutamente reprobables y rechazables, irrecuperables desde todo punto de vista, que no sirven de ejemplo para generaciones futuras y que no podían ser extrapolados a las centurias que nos ocupan. La obra jurídica se admira; la obra política se rechaza o desprecia, así que usualmente será silenciada para evitar siquiera la mínima tentación de invocarla ${ }^{14}$.

La exposición que sigue se dividirá en dos grandes apartados: un primero, de corte teórico, que se centrará en la visión que acerca de Alfonso X se forja en el siglo XVIII y a comienzos del siglo XIX, con el protagonismo capital de dos de los más relevantes historiadores patrios del momento, F. Martínez Marina y J. Sempere y Guarinos, cuyas opiniones (sobre todo, como se verá, las del primero) prácticamente perdurarán a lo largo del siglo XIX en el campo historiográfico sin oposiciones reseñables; a continuación, un segundo apartado, de corte más práctico, centrará la atención en el papel que se concede a Alfonso X dentro del momento constitucional gaditano, a través del examen de algunos de sus más representativos documentos, incluidos, sobre todo, los Diarios de Sesiones de las Cortes reunidas entre 1810 y 1814, en el seno del primer experimento liberal hispánico, fuente que, aunque no exclusiva, ni completa, sigue siendo inevitable punto de arranque para los efectos de este trabajo

Comencemos por la opinión académica -en buena parte, canónica- de los siglos XVIII y XIX. Bajo cierta perspectiva, se pueda afirmar que es F. Martínez Marina el que forja la doble visión alfonsina ya apuntada y la consolida frente a todo y frente a todos. Su sólida y enciclopédica obra, a la que me referiré de inmediato, da buena prueba de ello: el Ensayo, su trabajo más histórico y más relevante desde el punto de

\footnotetext{
${ }^{14}$ Para un encuadramiento del personaje, la mejor biografía sobre Alfonso X sigue siendo la de M. González Jiménez, Alfonso X El Sabio. Barcelona, 2004.
} 
vista científico, glosa las virtudes, bondades y benéficos efectos de la obra normativa alfonsina, aunque sin escatimar críticas al alejamiento respecto de la tradición nacional y a la superación con el tiempo de aquella magna obra por parte de los sucesivos códigos nuevos, mientras que la Teoría de las Cortes, su obra más política, beligerante, combativa y militante, califica directamente a Alfonso, sin tapujos, como el primer gobernante despótico, opuesto a la histórica realeza templada, mixta o moderada, que nos había regido desde tiempos góticos y medievales. El primer texto se ocupa del mundo jurídico en clara cadencia histórica; el segundo, del mundo político teniendo en cuenta el horizonte que conformaban las actuantes Cortes de Cádiz y la necesidad de explicarlas sin ánimo rupturista, esto es, no revolucionario. Fiel a su estilo y a su personalidad, Martínez Marina brinda en sus obras, a raudales, regalismo, tendencias anti-aristocráticas y un liberalismo propio y singular, donde se mezclan aspectos republicanos clásicos, escolasticismo, historicismo y virtudes cristianas ${ }^{15}$. Y no podía ser de otra forma.

2.1. Pero no fue el canónigo ovetense el primero que se aproximó a Alfonso X, ni mucho menos. No era materia virgen la referida al monarca medieval. Hasta el siglo XVIII, se vivió prácticamente de las reflexiones de Juan de Mariana, Esteban de Garibay, Nicolás Antonio y Juan Lucas Cortés, a modo de saberes traslaticios, que habían creado un compendio de verdades históricas, de auténticos tópicos, en torno al Rey Sabio $^{16}$. De Alfonso X se hablaba en relación a su obra jurídica, a las influencias y autoría de las mismas, a las fechas de creación y a los tiempos de su puesta en vigor, sin entrar a valorar contenidos, significados y sentidos de aquélla. Se hablaba, sobre todo, desde la Historia. Sin embargo, en el siglo XVIII son ya muchos los autores que nos introducen en el mundo de Alfonso X desde la perspectiva histórico-jurídica, combinando esas dos fuentes de conocimiento complementarias, añadiendo un componente hasta ahora no tomado en consideración, el que venía del horizonte jurídico, ya que la obra alfonsina era Historia sin dejar de ser Derecho del momento y era Derecho precisamente por esa pertenencia a la Historia. Alfonso ya no es tema exclusivo de eruditos historiadores. Los juristas comienzan a hablar de él, normalmente en términos llenos de elogio por su impresionante e imprescindible legado jurídico. Así, Alfonso X es calificado como el Salomón hispánico (usque Salomonis illius Hispaniae), en expresión de J. Lucas Cortés, epígono de los tiempos barrocos ${ }^{17}$. Fernández

\footnotetext{
${ }^{15}$ Vid. F. Tomás y Valiente, Martínez Marina, historiador del Derecho. Madrid, 1991, pp. 61 ss.; y P. Fernández Albaladejo, "Observaciones políticas: algunas consideraciones sobre el lenguaje político de Francisco Martínez Marina”, en A. Iglesia Ferreirós (ed.), Estat, Dret i Societat al segle XVIII, ed. cit., pp. 691-714 (= también aparecido, bajo el título "El cristianismo cívico de Martínez Marina”, en el volumen Materia de España, ed. cit., pp. 323-350).

${ }^{16}$ Vid. A. Iglesia Ferreirós, “Alfonso X, su labor legislativa y los historiadores”, en Historia, Instituciones, Documentos, $\mathrm{n}^{\circ} .9$ (1982), pp. 9-112.

${ }^{17}$ Cfr. G. E. de Frankenau, Sagrados Misterios de la Justicia Hispana, ed. cit. Sectio II. De Partitarum
} 
Prieto Sotelo inicia el camino laudatorio: legislación heroica y excelente, arreglada a la razón natural, es el calificativo que le merecen los textos alfonsinos ${ }^{18}$. De las Partidas dice Fernández de Mesa que son el libro central de las leyes de España y gloria de nuestra Nación, con un valor superior a todas las bibliotecas imaginables tanto por su autoridad como por su bondad, elogio éste que dirigió en su momento Cicerón a las Leyes de las XII Tablas y que hizo suyo Nicolás Antonio respecto al texto indicado $^{19}$. No obstante su dependencia del Derecho romano, aquellas leyes alfonsinas lo suavizan y dulcifican, lo adaptan, mejorando sus duresas, declarando sus obscuridades, y desidiendo las dudas de los Autores que en aquel tiempo se disputavan, ò que comprehendiò podian susitarse $e^{20}$. No es puro Derecho Común, sino que hay aditamentos patrios. Alfonso es ya el principal legislador de nuestra Historia, el más universal, por encima de los viejos reyes visigodos y de cualquier otro monarca del Medievo, y se le reconocen todos los méritos al respecto. Comienzan a fijarse otros lugares comunes en relación a su obra como esa dependencia abusiva respecto del Derecho romano foráneo, si bien matizada o mediatizada por la titánica labor de adaptación pergeñada por el monarca castellano, prueba evidente de su sabiduría proverbial y de su capacidad de trabajo ${ }^{21}$. Dos mundos parecen darse la mano con Alfonso $\mathrm{X}$ : el culto, el europeo, el que viene de fuera, el del Derecho romano-canónico, y, por otro lado, el tradicional, el autóctono, el propio del viejo Derecho castellano. El rey

legibus et Foro Regio Castellae, § I), pp. 144-145. Para una valoración de la obra alfonsina, tomada de Nicolás Antonio, cfr. § IV-VII, pp. 148 ss.

${ }^{18}$ Cfr. A. Fernández Prieto y Sotelo, Historia del Derecho Real de España, en que se comprehende la noticia de algunas de las primitivas Leyes, y antiquissimas Costumbres de los Españoles: la del Fuero antiguo de los Godos, y las que se establecieron despues que comenzò la Restauracion de esta Monarquia, hasta los tiempos del Rey Don Alonso el Sabio, en que se instituyeron el Fuero Real, y las siete Partidas. Madrid, 1738. Libro III, Caps. XI-XXI, pp. 366 ss.

${ }^{19}$ Cfr. T. M. Fernández de Mesa, Arte histórica y legal, de conocer la fuerza, y uso de los Drechos Nacional, y Romano en España. Y de interpretar aquel por este, y por el propio origen. Dos tratados utilissimos, assi para los Theoricos, como para los Practicos del Drecho Español, pues en ellos se incluye la Historia de dichos Drechos en esta Monarquia; y principios legales, conducentes para formar estas Artes, y se reduce todo à reglas ciertas (...). Valencia, 1747. Tomo I. Libro I, Cap. VIII, § I. 104, p. 59. Para las relaciones entre Derecho nacional y Derecho Común, cfr. Tomo I. Libro II, Examínase la fuerza, y uso de entrambos Drechos en esta Monarquía por los principios Legales, pp. 95 ss., con abundante uso de las Partidas y demás obras alfonsinas, así como de la mejor literatura del Ius Commune, lo mismo que en sede de interpretación, en Tomo II. Libro I. De los principios y reglas de la interpretación por estos dos medios, y uso de los Autores à este fin, pp. 1 ss.

${ }^{20}$ Cfr. T. M. Fernández de Mesa, Arte histórica y legal, ed. cit. Tomo I. Libro I, Cap. VIII, § II. 109, pp. 62-63.

${ }^{21}$ Cfr. P. Mora y Jaraba, Tratado crítico, ed. cit. Cap. IV, 206, p. 170. Lo reitera, tiempo después, J. Pérez Villamil, en su Disertacion sobre la libre multitud de abogados: si es útil al Estado, ed. cit., XI, pp. 8-11, cuando afirma de las Partidas que son obra más digna de Roma que de Castilla, texto que fracasó porque no pervivían ni las costumbres romanas, ni la forma de gobierno, ni, por descontado, el carácter de los vasallos era el mismo que en tiempos imperiales: "No se pude dudar, despues de leer las Partidas, que le hizo suyo [al Derecho romano] del modo mas singular que alguna de las demás naciones". 
parece haber conseguido un cierto equilibrio entre tales dos tendencias: ha conseguido forjar un Derecho nuevo que bebe del primer manantial, pero sin renunciar al segundo de modo íntegro. Precisamente, las críticas irán llegando cuanto mayor sea la distancia con respecto al Derecho castellano, en una línea que recuerda mucho al padre Burriel, exponente del mayor grado de erudición castellanocéntrica de la centuria ${ }^{22}$. En este contexto, las obras de Alfonso X se describen y se valoran de forma positiva sin excepciones, tanto en el fondo como en la forma. El sentido de la armonía es la nota destacada de las Partidas y así lo expone, por ejemplo, Campomanes, para quien se recurrió al mejor Derecho del momento, sin renunciar al Derecho nacional, combinándolos de un modo casi perfecto ${ }^{23}$, aunque no todos están de acuerdo en tal parecer valorativo ${ }^{24}$. Y, por supuesto, siempre comparece la vertiente práctica: se usan las Partidas para justificar y sustentar ese Derecho Público Hispánico, como lo hace Pedro José Pérez Valiente, es decir, como normas que integran ese caudal normativo que disciplina el ejercicio del poder por parte del monarca, la norma o conjunto de derechos según la cual deben dirigir sus acciones acerca del estado público los que viven en una sociedad civil ${ }^{25}$. Clavijo y Fajardo, no obstante su demoledora crítica al

${ }^{22}$ Cfr. "Carta del padre Burriel a don Juan de Amaya”, ed. cit., n 57-64, pp. 88 ss, ocupándose con detenimiento del Fuero Real.

${ }^{23}$ Cfr. P. Rodríguez de Campomanes, "Reflexiones sobre la jurisprudencia española”, ed. cit. Fuentes del Derecho Español. I, p. 140: "Luego se recurre a las Leyes de la Partida en que esta recopilada toda la Jurisprudencia civil de los Romanos y Canonica con las Costumbres antiguas de España"; y Cap. III. Modo de dirigir los estudios de jurisprudencia en España, p. 162: “(...) como asimismo las de las Siete Partidas, cuya colección que es el nervio de nuestra Jurisprudencia y por lo mismo debería leerse antes que la Recopilacion, es la mas famosa obra que se conoce en su línea, pues en ella se encuentran todo lo mas bien dicho en las leyes civiles de los Romanos y Canonicas, en las obras de los sabios antiguos y costumbres de España".

${ }^{24}$ Cfr. M. A. de la Gándara, Apuntes sobre el bien y el mal de España, ed. cit. §. 95, p. 192: "En las excelentes Leyes de Partida quiso el Rey Don Alfonso (o fuese su padre) seguir un método más conforme a mi propósito. Pero como para su formación, se hizo poco más que reducir a un cuerpo Castellano la mayor parte de las leyes Civiles y canónicas del derecho común que gobernaba entonces, sin examinar demasiado, si en todos puntos era útil a los Reyes de Castilla lo que en su tiempo había sido conveniente a los Emperadores del Occidente; y Corte Romana, necesitamos confesar de buena feé, que hay en ella varias contradicciones y artículos que no conducen ni a las regalías actuales de la Corona, ni al sistema presente de las Naciones, ni al derecho público, y privado de España, a la felicidad de la Nación, ni a la prosperidad y florecimiento del Estado en común"; o L. de Arroyal, Cartas económico-políticas (Con la segunda parte inédita), ed. cit. Segunda Parte. Carta Primera, pp. 171 ss., en una línea abiertamente liberal, quien llega a afirmar que Alfonso X se comportó antes como obispo que como rey y que, por todo ello, en Castilla no hay rastro de Constitución alguna, salvo la costumbre, la fuerza y la religión como componentes antitéticos de una estructura política caduca y superada por la realidad de los tiempos o que estaba en trace de serlo.

${ }^{25}$ Cfr. P. J. Pérez Valiente, Derecho Público Hispánico, ed. cit. Tomo I. Advertencia proemial con que el autor, hecha valer la enseñanza del Derecho Público, da cuenta al lector de argumento y obra, XV, p. 51. A modo de ejemplo, cfr. Tomo I. Libro I, Cap. X, 25, p. 144; Cap. XIII, 50, p. 172; Cap. XVII, 4, p. 207; y Tomo II. Libro II, Cap. XV, 17, 21 y 22, pp. 380-382; Cap. XVI, 40 y 41, pp. 394-395; Cap. XVII, 28, 29, 32, 33 у 35, pp. 403-405; Cap. XVIII, 9, p. 409; Cap. XIX, 5 y 10, pp. 414-415; Cap. XX, 
sistema jurídico imperante, formado por piezas de diversa procedencia espacial y temporal, y no obstante su decidida apuesta por un Código simple, sencillo y en lengua propia, compuesto de pocas y claras leyes, no escatima elogios a las Partidas, aunque reconoce, con dolor, que se ha procedido a su olvido. Es el diagnóstico del siglo en relación al Derecho nacional: el olvido o el ocultamiento de nuestro pasado jurídico, sepultado por otros Derechos extraños, y todo ello consentido, abierta o tácitamente, por los reyes ${ }^{26}$. Cornejo afirma que son las Partidas, de entre todas nuestras leyes, las que merecen mejor valoración, estima y aplauso, destacando de las mismas, además de su contenido sabio y justo, una coordinación muy arreglada, su laconismo sin rozar la oscuridad por insuficiencia o defecto de palabras, y su marcado tono didáctico, dulce atractivo á su estudio ${ }^{27}$. El doctor Castro continúa la misma dirección exegética: tras la loable labor de su padre, Alfonso X pasa a ser, sin discusión posible, el mejor legislador que tuvo España ${ }^{28}$. Forman, en fin, las bases de nuestro Derecho Público, como pone de manifiesto López Oliver, en su exaltación del poder absoluto del monarca ${ }^{29}$, e implícitamente hace lo propio A. Capmany al hablar del nuestro como un régimen monárquico basado en leyes fijas y fundamentales que sostienen el conjunto de reinos que integran la Corona final resultante ${ }^{30}$.

La cosa no parece cambiar si examinamos algunos de los textos más exitosos y celebrados, aproximándonos ya al final del siglo ${ }^{31}$. Por ejemplo, I. Jordán de Asso y M. de Manuel Rodríguez trazan en la Introducción a su conocido manual, las Insti-

3, 15 y 43, pp. 422, 424 y 428; Cap. XXI, 51 y 74, pp. 450 y 455; y Cap. XXI, 1, 7, 8, 12, 16, 24, 26, 27, 29 y 38, pp. 464-467, 469-472.

${ }^{26}$ Cfr. J. Clavijo y Fajardo, "Pensamiento XVI. Sobre la necesidad de formar un cuerpo de Leyes completo en el Idioma Patrio, y corriente", en El Pensador, ed. cit. Tomo II, pp. 61-92, específicamente, p. 85.

${ }^{27}$ Cfr. A. Cornejo, Diccionario historico, y forense, ed. cit. Prólogo, pp XI-XII.

${ }^{28}$ Cfr. J. F. de Castro, Discursos críticos, ed. cit. Tomo I. Libro I, Discurso IV, pp. 43 ss.

${ }^{29}$ Cfr. A. López Oliver, Verdadera idea de un principe, formada de las Leyes del Reyno que tienen Relacion al Derecho Público, en que se trata del Sumo Imperante; de los Derechos Supremos de Regalía, ó Mayestaticos; y de la Politica y Gobierno de un Estado, asi en la Paz, como en la Guerra. Valladolid, 1786. ${ }^{30} \mathrm{Cfr}$. A. [Capmany] Montpalau, Descripcion Politica de las Soberanias de Europa. Contiene un Estado Geografico, Historico, y Economico de todos los Imperios, Reynos, Repúblicas, y demás Estados Soberanos, que existen actualmente en esta parte del mundo, con la noticia de la fundacion, constitucion, policía, poblacion, títulos y fuerzas de cada uno de ellos. Madrid, 1786. Descripcion política del Reyno de España, pp. 203 ss.

${ }^{31}$ Si bien inédita en su mayor parte, la obra de Alfonso X preocupa asimismo a Rafael de Floranes, quien se muestra profundo conocedor de la vida foral castellano-leonesa (pero no sólo de esos territorios) y no puede menos que reconocer el carácter de punto final que los textos del citado monarca suponen para todo ese entramado del Derecho medieval. En todo caso, Floranes es un historiador ilustrado (aunque ni regalista, ni liberal), esto es, crítico como el que más, partidario de una suerte de Historia total, polifacética, en varios frentes, de base documental y jurisprudencial, si bien lastrado por una querencia hacia la Historia pura antes que hacia el Derecho, lo que marca sus resultados finales y sus insuficiencias expositivas. Cfr. B. Clavero, "Leyes de la China", cit., pp. 218-220; y M. Rodríguez Gil, Rafael de Floranes y Encinas, historiador del Derecho. Madrid, 2009, pp. 111 ss., específicamente, pp. 131, 138, 142-144, y 149-154. 
tuciones del Derecho Civil de Castilla, aparecido originariamente en 1771, pero objeto de múltiples ediciones posteriores en las que se añaden las notas históricas que ahora se comentan ${ }^{32}$, un fresco de la Historia del Derecho español, configurado por cuatro etapas, no necesariamente sucesivas: primera, la producción normativa de Concilios y de las primitivas Cortes (con el Fuero Juzgo y el Fuero Viejo, como principales resultados); segunda, la creación de los fueros municipales, que culmina con una etapa de superación de la pluralidad normativa de la que son arquetipos Fuero Real y Partidas alfonsinas; tercera, el Derecho generado en las Cortes como congresos generales de la nación; y, por último, el contenido en las pragmáticas, edictos, cartas acordadas y decretos del rey como supremo legislador del Reino. Sin menospreciar al Fuero Real, que desempeña una primera labor de uniformización para reducir los varios cuerpos civiles, que hasta su tiempo se habian publicado en Castilla, á uno solo, y unico para la administracion de Justicia en el Supremo Tribunal del Reyno ${ }^{33}$, Asso y De Manuel concentran su atención en las Partidas, de las que proclaman ser este Código nacional el más metódico que conocemos, compuesto de leyes romanas (lo que ha dado pábulo para cierta participación extranjera, como la de Azzo o alguno de sus discípulos), no obstante lo cual también se insertaron en sus preceptos muchas Leyes antiguas del Reyno, y que se consultaron las costumbres y Fueros de la nacion para que saliese un cuerpo legal perfecto y peculiar de nuestra España, para concluir con una pequeña referencia a las ediciones del texto ${ }^{34}$. Pérez y López llega al paroxismo adulador y autocomplaciente: tras detallar de un modo más minucioso los propósitos de Fernando III y Alfonso $\mathrm{X}^{35}$ y hablar brevemente del Fuero Real sin excederse ${ }^{36}$, afirma que las Partidas son el cuerpo completo que reúne Derecho público y particular, y todo lo abarca con método científico, sólido, cristiano, justo y equitativo. Texto sin parangón en toda Europa y excelente en cualquiera de sus aspectos, combina Derecho romano, Derecho canónico y asimismo fueros y an-

\footnotetext{
${ }^{32}$ Cfr. I. Jordan de Asso y M. de Manuel Rodríguez, Instituciones del Derecho Civil de Castilla, por los Doctores (...). Van añadidas al fin de cada titulo las diferencias que de este Derecho se observa en Aragon por disposición de sus Fueros. $5^{a}$ edición. Corregida notablemente, y aumentada la parte histórica que comprehende la introduccion. Madrid, 1792. Introducción, pp. I-CXXVI.

${ }^{33}$ Tanto es así que llegó a ser cuerpo civil y principal de la Nacion por vía jurisprudencial. Cfr. Ibidem, Instituciones, ed. cit. Introducción, pp. XL-XLII, para la política foral de Alfonso X, y pp. XLV-XLVIII, para Fuero Real y Leyes del Estilo.

${ }^{34}$ Cfr. Ibidem, Instituciones, ed. cit. Introducción, pp. XLVIII-L.

${ }^{35}$ Cfr. A. X. Pérez y López, Teatro de la legislacion universal de España é Indias, ed. cit. Tomo I. Discurso preliminar, §. 27, pp. XVIII-XIX: “(...) y por consiguiente para evitar su desolacion era preciso un Cuerpo de Leyes, ó Código general, que reuniendo todas las clases del Estado entre sí, sin perjuicio de una diferencia y graduacion ordenada, impidiese los temibles y perjudiciales efectos de la Anarquia feudal, contuviese á los Poderosos dentro de los limites de la obediencia debida al Soberano, precaviese las facciones y discordias entre las familias de los Magnates, y de sus respectivos vasallos, y diese reglas generales para el buen orden judicial y recta administracion de justicia”.

${ }^{36} \mathrm{Cfr}$. Ibidem, Teatro de la legislación universal de España é Indias, ed. cit. Tomo I. Discurso preliminar, $\S .28$, pp. XIX-XXI.
} 
tiguas costumbres del reino, limitando o minimizando así el carácter foráneo del mismo $^{37}$. Y añade en esa línea laudatoria llevada a su más alto punto lo que sigue:

Excelencia de las Partidas. Esta obra, para cuyo elogio no hallan palabras suficientes los Políticos y Sabios de la Nacion, comprehende tantas y tan sólidas reglas de Religion, Justicia, y Política christiana y acendrada, que seria necesario un grueso volumen para reunir las principales: y á la verdad, ¿qué disposicion mas arreglada y util que la que prescribe la sucesion del Reyno? ¿Quál mas conveniente y ventajosa que aquella que previene que el Rey debe honrar á todas las clases de vasallos útiles, con inclusion de los menestrales y artesanos, por los motivos que propone? ¿Dónde se halla otra mas conforme al espíritu del Evangelio, que la que ordena honrar y patrocinar al verdadero recien convertido á nuestra Santa Fé Católica? ¿Quál es mas humana y equitativa que la que reduce la infamia á los verdaderos delinqüentes, sin trascendencia á sus familias? ¿Y quál finalmente mas ventajosa á la población que la que promueve los matrimonios con razones las mas persuasivas? ${ }^{38}$

Las Partidas tienen la enorme virtud de obrar como el centro que condensa y aglutina lo propio y lo ajeno, lo nacional y lo foráneo, el pasado y el presente. Son el vértice sobre el que se ha construido el Derecho nacional, formado por variadas piezas entrelazadas entre sí en la forma y en el fondo ${ }^{39}$. J. P. Forner nos ilustra asimismo sobre esta magna obra legislativa con adjetivos que adornan a Alfonso, pero sin eludir sus imponentes creaciones políticas derivadas de todo este caudal jurídico: es sabio, grande, incomparable, pero, sobre todo, es autor de un código general tendente a crear una gran Nación a partir de un agregado confuso de pueblos y jurisdicciones como el que existía en el Medievo central. De ese deseo, nacen las Partidas, texto inmortal que no tiene parangón en ningún otro país, aunque fracasa en su aplicación práctica ${ }^{40}$.

${ }^{37} \mathrm{Cfr}$. Ibidem, Teatro de la legislación universal de España é Indias, ed. cit. Tomo I. Discurso preliminar, $\S .29$, p. XXI.

${ }^{38} \mathrm{Cfr}$. Ibidem, Teatro de la legislación universal de España é Indias, ed. cit. Tomo I. Discurso preliminar, $\S .30$, pp. XXI-XXII. Con referencias posteriores a las vicisitudes del texto alfonsino, §. 31-35, pp. XXII-XXV; y además §. 39, 43 y 53, pp. XXVII, XXX y XXXVII-XXXVIII.

${ }^{39} \mathrm{Cfr}$. Ibidem, Teatro de la legislación universal de España é Indias, ed. cit. Tomo I. Discurso preliminar, $\S .54$, pp. XXXVIII-XXXIX: "Siendo ahora una demostracion legal que todos los referidos Cuerpos y Leyes están enlazados estrecha y esencialmente, así en el modo como en la substancia, no debo detenerme en corroborarlo, ya por el medio de repetir que las Partidas son el centro de reunion de los Fueros anteriores, y del Derecho Civil y Canónico que insertan y autorizan, y de los Códigos y Resoluciones no recopiladas de uno y otro Derecho, que se refieren á las leyes de las mismas Partidas: ya recordando la razones de este estrecho enlace, por exemplo, que recayendo sucesivamente las alteraciones legales y políticas sobre el gobierno de una propia Nacion, que con dificultad varia su carácter, y su constitucion moral y fisica, impide mudarlo absolutamente, y era regular que siempre conservase muchas costumbres y fueros antiguos, y que los nuevos no hiciesen mas que modificarlos, dexándolos subsistentes en gran parte; pues á la verdad á presencia de ser un hecho demostrado la referida conexion esencial seria superabundante quanto se añadiese en su confirmacion".

${ }^{40}$ Cfr. J. P. Forner, "Discurso sobre el modo de formar unas instituciones de Derecho español. Parte Pri- 
J. Sala apenas introduce novedades en estas descripciones referidas ${ }^{41}$. Esta admiración, casi devoción, explica la labor editorial que se va a iniciar con respecto a algunos textos de Alfonso X que acaban por ser editados, conscientes como eran nuestros ilustrados, del valor histórico y jurídico que tales documentos traían consigo. Lo mismo se hace con aquellas piezas que integraban la Constitución histórica y que conformaban, por su forma y por su contenido, elementos fundamentales, en tanto que fundacionales, de la vida jurídico-política de la Monarquía, como acontece con el Ordenamiento de Alcalá, el Fuero Viejo o el Fuero Juzgo. Las correspondientes Academias tomarán cartas en el asunto. En todos ellos, había Historia, pero también, sobre todo, había Derecho, había saber y había poder, dualidad común en tiempos ilustrados. En todo caso, había palabras que tenían que ser clarificadas a la luz de ese espíritu historiográfico crítico aludido, como símbolo de la centuria, para desentrañar un significado más adecuado a los dos tiempos vitales comprometidos, tanto el de su origen como, sobre todo, el tiempo que los demandaba, la actualidad que procedía a revisarlos y a hacerlos aplicables. Se hace específicamente con el Fuero Real en el siglo XVIII y se hace con las Partidas en el XIX ${ }^{42}$. Incluso se va más allá y se facilita su difusión y manejo con la aparición de algunos diccionarios para simplificar la consulta de un material normativo tan amplio y de tan difícil comprensión dada su antigüedad ${ }^{43}$.

2.2. De Alfonso $X$ se conocía, pues, la autoría de tres obras jurídicas esenciales (Fuero Real, Leyes del Estilo, Partidas), que formaban parte capital de nuestras Leyes Fundamentales, de nuestra Constitución histórica, destacando por encima de todas ellas las Partidas, el texto más completo, extenso e intenso, sobre el cual se proyectaba una valoración dual: se afirmaba su trascendencia indiscutible, su perfección y su monumentalidad, pero no se silenciaba el cierto desagrado que provocaba el hecho de haberse inspirado para la mayor parte de sus leyes en normas romanas y canónicas. Sin embargo, la cosa no se detenía ahí. Incluso de esta valoración negativa cabía extraer enseñanzas positivas: el genio creador alfonsino había conseguido matizar

mera. Sobre la dificultad de formar unas buenas instituciones del derecho de España", en Obras de don Juan Pablo Forner, ed. cit. pp. 314 ss.

${ }^{41}$ Cfr. J. Sala, Ilustracion del Derecho Real de España, ordenada por don Juan Sala, pavorde de la Metropolitana Iglesia de Valencia, y catedrático de Prima de Leyes en la Universidad de la misma ciudad. Valencia, 1803. Tomo I. Breve historia del derecho de España, §. 6, pp. XI-XII.

${ }^{42}$ Vid. J. Vallejo, "E1 Fuero Real bajo las luces, o las sombras de la edición de 1781”, cit., pp. 611-643; y, con más detalle, “Academia y Fuero: Historia del Real en la Real de la Historia”, cit., pp. 419-484.

${ }^{43}$ Es el caso de D. Pérez Mozún, con su Diccionario alfabético, y ortográfico de las voces, que en sus célebres siete Partidas usó el Rey Don Alonso el Sábio, y al presente (año de 1789) ignoran los que se graduan doctos en este Siglo ilustrado, aparecido en su Estilo Legal Matritense en los Juicios Ordinarios, Extraordinarios, Sumarios, Executivos, Civiles, Criminales, y Mixtos: en los Eclesiásticos, Seculares, Regulares, y Monacales (...). Madrid, 1790. Tomo III, pp. 43-168 (también publicado, con algunas modificaciones, en Los Códigos españoles concordados y anotados. Madrid, 1848. Tomo IV. Código de las Siete Partidas, pp. 491-506). 
mucho tales acciones por medio de una dulcificación, debida al catolicismo, sin lugar a dudas, del rigor normativo romano-canónico, y a la inserción de instituciones, fueros y costumbres nacionales, es decir, castellanas, que las hacían, al menos en parte, más propias, más nacionales, más nuestras en su conjunto. Reconociendo la indudable dependencia externa, cuanto más castellano, mejor, parecen decir nuestros eruditos. Y eso era mérito del rey en ejercicio de su sabiduría. En esta dirección, quien crea el más sólido discurso sobre la obra legislativa alfonsina en el siglo XVIII, compendio de antiguas opiniones, es, sin lugar a dudas, Gaspar Melchor de Jovellanos ${ }^{44}$, no sólo en un plano estrictamente teórico o puramente histórico, sino también desde una perspectiva práctica a los efectos de asumir el legado jurídico de Alfonso X como compendio del Derecho histórico español y, como tal, susceptible de ser aplicado en los convulsos tiempos en que vive este ilustrado asturiano. Jovellanos sabe qué son las Partidas, puede trazar su genealogía, pero también qué contienen o dicen aquéllas en tanto en cuanto que Derecho de la Monarquía, de obligado cumplimiento por parte de todo el mundo sin excepciones.

El texto donde se ocupa de forma más pormenorizada de estos aspectos es en su conocido discurso de ingreso en la Real Academia de la Historia. Allí postula de una forma abierta y natural la necesidad de estudiar nuestra legislación en perspectiva histórica, uniendo esas dos disciplinas para la buena y correcta formación de los juristas, con el propósito final de forjar una Historia civil de la Nación, de la que España estaba ayuna en ese preciso instante. En este trabajo, datado en el mes de febrero del año 1780, Jovellanos plantea una Historia de la Constitución española, desde tiempos visigodos, donde alcanza sus perfiles más definidos y claros (poder monárquico mo-

\footnotetext{
${ }^{44}$ Para el cual, disponemos de la bibliografía citada supra en Parte Primera, nota nº 40; y además las compilaciones de S. M. Coronas González, Jovellanos. Justicia, Estado y Constitución en la España del Antiguo Régimen. Gijón, 2000; de S. Scandellari, Proposte di riforme legislativa, ed. cit., pp. 145 ss.; y Da Bayonne a Cadice. Il proceso di trasformazione costituzionale in Spagna: 1808-1812. Messina, 2009, pp. 125 ss.; y de I. Fernández Sarasola, El pensamiento político de Jovellanos. Seis estudios. Oviedo, 2011. Para legados anglosajones evidentes en el personaje, vid. C. Álvarez Alonso, "La influencia británica y la idea de Constitución en Jovellanos", en Il modello costituzionale inglese, ed. cit., pp. 507-543; y, más en detalle, M. C. Lara Nieto, Ilustración española y pensamiento inglés: Jovellanos. Granada, 2008. A modo de síntesis, la reciente y completa aproximación conjunta AA. VV., Jovellanos, el valor de la razón (1811-2011). Edición de Ignacio Fernández Sarasola, Elena de Lorenzo Álvarez, Joaquín Ocampo Suárez-Valdés y Álvaro Ruíz de la Peña Solar. Gijón, 2011, junto con los trabajos hagiográficos de J. E. Canseco Canseco, La evolución política e ideológica de Jovellanos. Gijón, 2011; J. M. Gea, Jovellanos o la virtud del ciudadano. Gijón, 2011; J. M. Souto Rodríguez, Filosofía e Ilustración en Jovellanos. Introducción a su pensamiento. Oviedo, 2011; V. Llombart, Jovellanos y el otoño de las Luces. Educación, economía, política y felicidad. Gijón, 2012; y P. Cerezo Galán, "El litigio por la soberanía. Jovellanos ante las Cortes de Cádiz", en Anales de la Real Academia de Ciencias Morales y Políticas. Año LXIV, n ${ }^{\circ}$ 89. Curso Académico 2011-2012 (2012), pp. 59-92, así como la última biografía de M. Álvarez Valdés y Valdés, Jovellanos: vida y pensamiento. Oviedo, 2012. Vid. asimismo mi trabajo "Jovellanos y sus Reflexiones sobre la constitución, las leyes, usos y costumbres de Castilla", a aparecer en los estudios en homenaje al Prof. Santos M. Coronas. Oviedo, 2013 (en prensa).
} 
derado, catolicismo, asesoramiento del rey por medio de Concilios, imposibilidad del absolutismo o del despotismo, etc.), hasta tiempos modernos, observando cómo se van produciendo cambios y modificaciones en los instantes intermedios, sobre todo en el Medievo, aflorando una cierta Constitución de corte feudal que reemplaza a la anterior. La fragmentación política (señoríos, concejos) y jurídica (fueros, cartas-pueblas), más acentuada en Castilla que en León, da pie a una labor de remodelación que tiene lugar en tiempos de Fernando III y, sobre todo, de Alfonso X, quienes tratan de poner fin a ese sistema donde los señores lo podían todo, el rey poco y el pueblo nada, dando origen, en tal poliarquía, a un gobierno vario, incierto y dividido. Las Partidas serían el compendio de todo ello, el remedio jurídico que traería consigo el cambio político: el código más completo, sabio y bien ordenado que pudieron producir aquellos tiempos duros, un tesoro indiscutible [precedido del Fuero de las Leyes (o Real), primer intento puramente castellano de unificación jurídica], aunque ni las unas, ni el otro contaron con el beneplácito del reino y de sus estamentos y, por eso mismo, fracasaron como cuerpo de Derecho general, volviendo la vigencia del Fuero Viejo en tierras de Castilla hasta 1348. Pero Jovellanos va más allá y se introduce con detalle en el interior de las Partidas. Marcan éstas, dice nuestro autor, una nueva etapa en la Historia de la legislación hasta el punto de trastornar nuestra jurisprudencia nacional y hacerle cambiar su rumbo. Con ellas, se introduce el gusto por las leyes romanas, copiando estas leyes citadas y también (y ahí lo más grave) las opiniones de los jurisconsultos italianos, lo cual marcó el destino interpretativo de nuestro principal cuerpo legal. Los estudios universitarios y la formación de una clase letrada, educada en aquella línea romanizante, hicieron el resto. Todo fue dominado por la jurisprudencia romana y eso provocó la inserción entre nosotros de un Derecho diferente, cuando no contrario, a las leyes nacionales. El otro flanco, el canónico, tampoco queda exento de críticas. Gracias a las Partidas se introdujo entre nosotros el Derecho canónico de los siglos XII y XIII, a pesar de contar con una tradición jurídica canónica nacional, y, con ese Derecho ajeno, la opinión, apócrifa en algunos casos, de juristas de allende los Pirineos, todavía no desterrada cuando el discurso se escribe. Jovellanos denuncia, por tanto, la suplantación de toda una tradición jurídica nacional por esto dos Derechos extranjeros, suplantación no total, pero sí relevante y de efectos concluyentes, tanto desde una perspectiva legal como jurisprudencial.

Sin embargo, no todo es negativo en este proceso de asimilación: las Partidas causaron un bien efectivo a la Nación entera pues con ellas se introdujeron en España los mejores principios de la Equidad y de la Justicia natural, y se templó así la rudeza de la antigua legislación, así como de las antiguas ideas y costumbres. Toda la obra alfonsina está surcada de sabios documentos morales y políticos, obra de los antiguos filósofos y de los Santos Padres, los cuales provocaron una incitación al estudio de esa antigüedad, ya profana, ya cristiana, y a la adopción de muchas de sus máximas de Humanidad y de Justicia. Así, se fue suavizando la ferocidad y rudeza que inspiraban en los ánimos, la esclavitud feudal, el espíritu caballeresco y la ignorancia de 
los primeros siglos, lo que trajo consigo un bien preciadísimo: la libertad. El fortalecimiento paulatino del poder del rey y la aparición de las ciudades como enclaves libres de sujeción señorial provocaron, de forma combinada y en clara retroalimentación, que España comenzase a ser una Nación diferente, sabia, guerrera, industriosa, comerciante y opulenta. Los tiempos posteriores no harían sino certificar el acierto de las medidas alfonsinas de cara a la creación de un nuevo poder monárquico más contundente y más efectivo que alcanzará su cénit con los Reyes Católicos, sin despreciar la voz del reino, sino integrándola junto con la voluntad regia (las Cortes serían la expresión máxima de este propósito que no era más que la simple recuperación de la vieja monarquía mixta gótica). Después vendría la decadencia de la que se puede salir con una recuperación de esas esencias pretéritas, para lo que se requiere esa reclamada Historia civil que permita conocer la Constitución, las jerarquías, la legislación y las costumbres, lo que lleva indefectiblemente a la obra alfonsina como punto de arranque de todo ello ${ }^{45}$. El valor de las Partidas no sólo se mide en términos jurídicos, de lo que dan buena cuenta otros testimonios variados de Jovellanos posteriores a 1780, en los que se insiste en que, con todo y sus influencias foráneas, aquéllas seguían respetando nuestra Constitución, convirtiéndose en parte sustancial de la misma, y contribuían a mantener vivas nuestras viejas costumbres ${ }^{46}$. También desde el punto de vista filológico y de estilo, como afirma al estudiar la vinculación entre lengua y legislación, ahora con ocasión de su ingreso en la Real Academia, se destaca el gusto literario y la elegancia de las Partidas, las cuales sorprenden por proceder de la época bárbara y oscura en que fueron escritas, dotadas de un lenguaje puro y majestuoso, si bien precisado de adaptación a la nueva realidad que tienen que regular ${ }^{47}$. El Reglamento del Colegio de Imperial de Calatrava desnuda el interior de las Partidas, que, como Derecho patrio, habrán de ser enseñadas junto con la Nueva Recopilación, pero con la advertencia de que su contenido ha de ser examinado con rigor para evitar sorpresas y para conocer la procedencia de cada precepto. Aquí Jovellanos es el primero que identifica fuentes de la obra alfonsina, siempre de acuerdo con esa dualidad ya conocida, con esa pugna entre Derecho romano-canónico y Derecho patrio: la Partida $1^{\text {a }}$ procede del Decreto de Graciano y de la obra de los juristas boloñeses; la $2^{\mathrm{a}}, 4^{\mathrm{a}}$ y $7^{\mathrm{a}}$ tienen sus fuentes en la escuela arábigo-peripatética y en los antiguos fueros, costum-

\footnotetext{
${ }^{45}$ Cfr. G. M. de Jovellanos, "Discurso leído por el autor en su recepción á la Real Academia de la Historia, sobre la necesidad de unir al estudio de la legislación el de nuestra historia y antigüedades", ed. cit., pp. 288 ss., especialmente, pp. 295-297.

${ }^{46}$ Así, por ejemplo, en su correspondencia. Cfr. G. M. de Jovellanos, Obras Completas. Tomo III. Correspondencia $2^{\circ}$, ed. cit., $\mathrm{n}^{\circ}$. 835. De Jovellanos a Antonio Fernández de Prado (Gijón, 17 de diciembre de 1795), pp. 175-184, con reivindicación de la Partida Segunda, en pp. 180-181; nº 1.064. De Jovellanos a Juan Nepomuceno Fernández San Miguel (Gijón, 19 de junio de 1797), pp. 313-322, desvelando detalles sobre la entrada en vigor de la Partidas, en pp. 313-317; y nº 1.321. De Jovellanos a Juan Francisco Masdeu (Gijón, diciembre de 1800), pp. 596-604.

${ }^{47}$ Cfr. G. M. de Jovellanos, "Discurso leído en su entrada á la Real Academia Española, sobre la necesidad del estudio de la lengua para comprender el espíritu de la legislación”, ed. cit., p. 300.
} 
bres, fazañas y leyes de Castilla; la $3^{\mathrm{a}}, 5^{\mathrm{a}}$ y $6^{\mathrm{a}}$, por fin, arrancan de los ritos y fórmulas del fuero eclesiástico y de las mismas fuentes nacionales y extranjeras ya citadas. Aparece, en su plenitud, la visión maniquea acerca de las Partidas, tan del gusto ilustrado. La realidad histórica es la que es y contra ella no se puede combatir: en las Partidas, hallamos una invasión romanística y canónica indiscutible, pero eso no impide que se salve el expediente analizando y descubriendo todos aquellos elementos puramente nacionales que comparecen en sus preceptos. Esos son los que hacen que se pueda reivindicar el texto, que se pueda presentar como algo típicamente español, por castellano, congruente con el pasado y con la anciana Constitución. Es un compendio de la buena y de la mala doctrina, con todas las virtudes y los vicios de sus textos originarios, por lo que han de ser leídas y manejadas con el mayor cuidado y discernimiento, concluye el erudito asturiano, para, de esta forma sutil y velada, reivindicar una vez más el valor superior de la obra alfonsina precisamente por su concordancia con la tradición nacional, presente a lo largo de sus páginas y de muchos de sus pre$\operatorname{ceptos}^{48}$. Nada se dice del modelo político alfonsino: silencio elocuente que no nos puede sorprender. El ejemplo del Rey Sabio no vale en estos campos, máxime en unos tiempos, los de finales del siglo XVIII, en que está presente la sentida necesidad de reformar la Monarquía. Su invocación es contraproducente por lo que mejor no traerlo a colación. De Alfonso X se toma lo que vale la pena, lo que es aprovechable, y esto está condensado en su magna obra jurídica, por encima de cualquier otra creación.

Jovellanos no se detiene en este conocimiento teórico completo de las Partidas y de la restante obra alfonsina ${ }^{49}$. A lo largo de su actividad política, sobre todo en los convulsos años con los que se inicia el siglo XIX, tendrá que echar mano de este Derecho vigente para justificar medidas, decisiones y actitudes. Los sucesos que se siguen desde marzo de 1808, con una Monarquía descompuesta y una Nación en proceso de (re)constitución, hicieron de todo punto necesario recuperar los cuerpos normativos alfonsinos para justificar, desde la Historia, la forma de actuar o los posibles modos de comportamiento de las instituciones nuevas o de las supervivientes. Allí, en esa enciclopedia del saber jurídico de su época, se podría hallar respuesta a todas las inquietudes, dudas, vacíos y preguntas que se formulasen en pleno siglo XIX, siempre que se contara con la prudencia y con la sabiduría suficiente para proceder a una exégesis hodierna de esas normas que lo seguían siendo a pesar del tiempo transcurrido. Por tales motivos, pasajes de las Partidas, como P. 2, 19, 3, P. 2, 19, 4 o P. 2, 15, 3, son reputados como Leyes Fundamentales a los efectos de explicar el derecho de insurrección del pueblo cuando alguno se alzase contra el reino, el deber de ese pueblo para acudir en defensa del territorio o la justificación para el estable-

${ }^{48}$ Cfr. G. M. de Jovellanos, "Reglamento literario é institucional, extendido para llevar á efecto el plan de estudio del Colegio Imperial de Calatrava, en la ciudad de Salamanca", ed. cit., pp. 211-213.

${ }^{49}$ Por ejemplo, lo va a emplear con profusión en la "Memoria para el arreglo de la policía de los espectáculos y diversiones públicas y sobre su origen en España”, en G. M. de Jovellanos, Obras Completas. Tomo XII. Estudios sobre literatura. Edición de Elena de Lorenzo Álvarez. Oviedo, 2009, pp. 193-320. 
cimiento de una regencia, respectivamente, es decir, para explicar comportamientos que se estaban dando o apenas se habían dado en los primeros meses del año 1808, y para los cuales era posible una correcta subsunción lógica a la luz de los textos que conformaban nuestra Constitución histórica. Lo que subyacía era la intención clara de eludir cualquier sensación de ruptura, de quiebra y de consecuente vacío político o institucional, algo impensable en los ambientes intelectuales del momento. La revolución se rebajaba de intensidad y se relajaba viendo cómo esos acontecimientos no suponían inversión de nada, sino que tenían un encaje pleno y perfecto en los antiguos textos normativos, tenían una regulación aun con su excepcionalidad y caracteres drásticos, tal y como lo percibían y sufrían nuestros protagonistas. Nada quedaba al margen de aquellas ancianas previsiones legales. Los nuevos acontecimientos, sobre todo la invasión francesa y las abdicaciones reales en Bayona, parecían estar prefigurados en las leyes de las Partidas y nada había, pues, que temer: las eventuales respuestas derivadas de la sabiduría de Alfonso X seguían dando frutos tantos años después. Todo parecía ordenado y previsto en el código alfonsino, resultado de su redacción basada en una razón natural que no parecía haber caducado, sino estar de rabiosa actualidad para servir a los intereses de Monarquía y Nación, aun en tiempos de confusión e incertidumbre. No había que improvisar, ni crear nada nuevo, sino que tenían plena validez las antiguas recetas para sanar al enfermo cuerpo político ${ }^{50}$. Las Partidas servían como ejercicio erudito, historiográfico, pero asimismo como útil compendio normativo, interpretadas en provecho de un rey y de un reino que buscaban salir de las variadas crisis en las que andaban sumidos.

Todo en relación a Alfonso X parecer ser bueno, perfecto, pacífico y armónico, a la luz de las interpretaciones que he glosado hasta aquí, típicas del siglo XVIII, de

\footnotetext{
${ }^{50}$ Así, la literatura específicamente política de Jovellanos cobra un especial protagonismo en esta sede, sobre todo, la surgida en los tiempos de la Junta Central, donde se asiste a la generación de toda una nueva normativa para poner en marcha nuevas instituciones o para convalidar las ya existentes, sin descuidar el ensamblaje de todas ellas con la normativa tradicional en la que se apoyan o de la que traen causa en numerosas ocasiones. Es el modo usual de comportarse de Jovellanos y de los restantes hombres públicos del momento, eludiendo en cualquier instante la probabilidad de la ruptura y fomentando el encaje o el ajuste, forzado en ocasiones, de todo lo nuevo o aparentemente nuevo en el complejo institucional suministrado por el pasado. Cfr. G. M. de Jovellanos, Obras completas iniciadas por José Miguel Caso González. Tomo XI. Escritos políticos, ed. cit. Dictamen de la Comisión de Cortes, dirigida a la Junta Central, a propósito del informe remitido por la Junta de Ceremonial (18 de diciembre de 1809), pp. 301 ss.; Dictamen de la Comisión de Cortes que acompañó a las convocatorias por estamentos (8 de enero de 1810), pp. 319 ss.; [Exposición sobre los derechos de sucesión al trono] (Sevilla, 19 de enero de 1810), pp. 330 ss.; y, sobre todo, en su Memoria en defensa de la Junta Central (1811), pp. 353 ss. (por ejemplo, en pp. 401, 417 ó 448) y en sus documentos anexos (así, Apéndices y notas a la memoria de don Gaspar de Jovellanos, $\mathrm{n}^{\circ}$. V. Dictamen del autor sobre la institución del gobierno interino, pp. 623 ss., con empleo de Partida 2, 15, 3 y Espéculo 2, 16, 5; $\mathrm{n}^{\circ}$ XII. Consulta sobre la convocación de las Cortes por estamentos, pp. 685 ss.; o $\mathrm{n}^{\circ}$ XXIV. Representación dirigida desde Muros de Noya, en marzo de 1810, al Consejo Supremo de Regencia por los vocales de la Junta Suprema don Gaspar de Jovellanos y Marqués de Campo Sagrado, y extendida por el primero, pp. 760 ss.; y en las Notas a los Apéndices. Primera Nota, p. 796, con cita de Partida 2, 1, 10.
} 
ese siglo devoto de la Historia hasta extremos inimaginables, aunque sin escatimar críticas a la misma y sobre la misma. El cambio de centuria trae aparejado un cambio en la valoración, anteriormente sólo insinuado, cuando se toma conciencia del carácter intrínseco de su obra jurídica más sublime, apartada de la tradición nacional, y cuando se reflexiona abiertamente sobre los defectos inherentes al modelo político que el monarca trató de llevar a la práctica. Hay conocimiento competente de la obra de Alfonso X, valoración encomiástica de la misma, pero su pecado original, sus fuentes, sus compiladores o auxiliares, y el trasfondo político de todo su reinado evitarán cualquier posibilidad de remisión en el juicio al que va a ser sometida aquélla de inmediato. Se está vislumbrando la posibilidad de una condena, si no íntegra, sí, al menos, parcial, lo que pone en el disparadero la obra alfonsina a los efectos de convalidarla para con los nuevos tiempos que se van a inaugurar, es decir, o se modifica su profunda e intensa dependencia del Derecho romano y del Derecho canónico, volviendo al Derecho nacional, o se prescinde de la misma para articular una reforma drástica y radical de toda la legislación con el fin de hacer surgir un Código moderno a todos los efectos (político, civil y criminal), si bien con las limitaciones que la época imponía en una línea, antes que nada, de mejor ordenada compilación del Derecho dado, sin cambios de fondo reseñables. Llegamos así a la obra de F. Martínez Marina, quien, como se ha anticipado líneas atrás, elaborará el discurso canónico sobre Alfonso X vigente a lo largo del siglo XIX y buena parte del siglo XX en la doble dirección indicada: prevalencia del legado jurídico sobre el legado político, oculto, silenciado, cuando no minusvalorado o despreciado ${ }^{51}$.

\footnotetext{
${ }^{51}$ A modo de recapitulación sobre el personaje en cuestión, vid. A. Posada y R. Riaza, "Martínez Marina", en Revista de Ciencias Jurídicas y Sociales. Año XVI, nº 65 (octubre-diciembre, 1933), pp. 479-542, especialmente, la parte redactada por el segundo, "Las ideas políticas y su significación dentro de la obra científica de Martínez Marina”, en pp. 511-526; J. A. Maravall, "El pensamiento político en España a comienzos del siglo XIX: Martínez Marina”, en Revista de Estudios Políticos, nº 81 (mayo-junio, 1955), pp. 29-82 [= reproducido después en F. Martínez Marina, Discurso sobre el origen de la monarquía y sobre la naturaleza del gobierno español. Edición y estudio preliminar de José Antonio Maravall. Madrid, 1957, pp. 7-78. (Reimpresión. Madrid, 1988)]; R. Morodo, "La reforma constitucional en Jovellanos y Martínez Marina", en Boletín Informativo del Seminario de Derecho Político. Universidad de Salamanca. $2^{\mathrm{a}}$ época, n ${ }^{\mathrm{o}}$ 29-30 (1963), pp. 79-93 [= E. Tierno Galván y R. Morodo, Estudios de Pensamiento Político. Madrid, 1976, pp. 151-171; y R. Morodo, Las Constituciones de Bayona (1808) y Cádiz (1812). Madrid, 2011, pp. 151 ss.]; J. M. Pérez-Prendes, "Introducción”, en F. Martínez Marina, Teoría de las Cortes. Madrid, 1979. Tomo I, pp. 9-51; y "Martínez Marina y Blanco White sobre Cortes de Castilla", en Revista de la Facultad de Derecho de la Universidad Complutense, nº 73 (1987-1988), pp. 317-332; J. Varela Suanzes-Carpegna, Tradición y Liberalismo en Martínez Marina. Oviedo, 1983 [= Política y Constitución en España (1808-1978), ed. cit., pp. 225-278]; J. I. Sánchez Amor, “Algunas consideraciones sobre la influencia de Martínez Marina en las Cortes de Cádiz", en Revista de Estudios Políticos. Nueva Época, no 62 (octubre-diciembre, 1988), pp. 89-129; J. R. Torres Ruiz, "Martínez Marina y la Declaración de Derechos de 1789: un modelo de recepción reformista del espíritu revolucionario francés", en Revista de Estudios Políticos. Nueva Época, no. 67 (enero-marzo, 1990), pp. 189-212; J. L. Bermejo Cabrero, "Tríptico sobre Martínez Marina”, en AHDE, nº 65 (1995), pp. 219-265; J. M. Portillo Valdés, “¿Existió una antigua Constitución española?”, en A. Romano (a cura di), Il modello costituzio-
} 
2.3. El punto de partida es el Ensayo que, como se sabe, operaba en su concepción inicial como prólogo para la edición de las Partidas que la Real Academia de Historia efectuará entre los años 1807 y 1808. Finalizado en 1806, motivos políticos, antes que los puramente científicos o técnicos, frustran la mentada inserción preliminar del texto (a pesar de que la Academia, con sus censores a la cabeza, la entendieron obra útil, nueva y original en su clase, digna de publicación, algunos vocales, considerando la prolijidad del discurso, y fijando su atención en algunas noticias, expresiones y palabras que en su dictámen acaso pudieran á la sazon desagradar, producir disgustos y ofensiones y comprometer á la academia, propugnaron que no debía adoptarse por el cuerpo ni publicarse al frente del código de las Siete Partidas ${ }^{52}$ ), pero no impiden que el volumen aparezca por separado y conozca un éxito inusitado que explicará sus reediciones a lo largo del siglo XIX y la extraordinaria dependencia de toda nuestra incipiente Historia jurídica respecto del mismo y de sus ideas centrales ${ }^{53}$. Martínez Marina comienza loando la obra de Alfonso X, en términos queridos a la Ilustración, atribuyendo al monarca ciencia y felicidad como complementos aparejados en la labor de gobierno dirigidos al bien común de los vasallos ${ }^{54}$, y, más específicamente, luchando contra todos los que no respetaban el derecho de propiedad, la libertad civil o la subsistencia segura, además de contra la fiereza de las costumbres y la altanería y orgullo de los poderosos, contra el desconocimiento del Derecho Público, y contra sentencias arbitrarias dirigidas por el antojo y pronunciadas a la aventura $^{55}$. Los dos grandes enemigos a los que se enfrenta el Rey Sabio son la pluralidad jurídica, con inclusión de lugares que carecían de Derecho escrito y que se guiaban por comportamientos o ejemplos pretéritos abusivos e injustos (aquellas fazañas desaguisadas de las que habla el propio monarca), y esa nobleza levantisca, feudalizante y rebelde, presta a enfrentarse siempre al rey para la defensa de su posición privilegiada. Ambos factores hacían de todo punto imposible la gestión del reino. Frente a

nale inglese, ed. cit., pp. 574-585; y J. A. Escudero, "Estudio Introductorio", en F. Martínez Marina, Teoría de las Cortes. Oviedo, 2002. Tomo I, pp. XV-CLXXX.

${ }^{52}$ Cfr. F. Martínez Marina, Ensayo histórico-crítico sobre la antigua legislación y principales cuerpos legales de los Reynos de Leon y Castilla, especialmente sobre el Código de D. Alonso El Sabio, conocido con el nombre de las Siete Partidas. Madrid, 1808. Advertencia. Y continúa: "El autor en estas circunstancias, no teniendo por decoroso que la obra se imprimiese contra el juicio y atinado dictamen de aquellos ilustrados y respetables compañeros, determinó recogerla, suplicando á la academia tuviese á bien suspender las conferencias sobre esta materia, no pasar á ulteriores discusiones, y que se le entregase para hacer de ella el uso que tuviese por conveniente. Entónces el autor, con dictamen de varones prudentes, imparciales y de notoria literatura, trató de imprimir el discurso por lo que pueda influir en la ilustración pública".

${ }^{53}$ La segunda edición del Ensayo es del año 1834 y la tercera, de 1845, pertinentemente aumentadas y completadas. Cfr. M. C. Castrillo Lamas, "D. Francisco Martínez Marina: el hombre y su obra", en Medievalismo. Revista de la Sociedad Española de Estudios Medievales, nº 2 (1992), pp. 219-225. Para la supervivencia en los siglos XIX y parte del XX de Martínez Marína, cfr. infra nota $\mathrm{n}^{\circ} 83$.

${ }^{54}$ Cfr. F. Martínez Marina, Ensayo histórico-crítico, ed. cit., ${ }^{\mathrm{o}} 1, \mathrm{p} .1$.

${ }^{55}$ Cfr. F. Martínez Marina, Ensayo histórico-crítico, ed. cit., no 5-6, pp. 3-4. 
todo ello, se impone la sabiduría, también jurídica, de un monarca que, por medio del Derecho, trata de dar a su reino todo aquello de cuanto carecía y que se venía denunciando. El rey modelo es el rey sabio, el que introduce la sabiduría como factor esencial para el cumplimiento del Derecho: ese rey que no impone, sino que seduce y convence tratando de mostrar la intrínseca racionalidad de toda su obra jurídica. Para ello, se utiliza un argumento discursivo consistente en cargar las tintas sobre la situación previa a los solos efectos de mostrar lo benéfico y lo salvífico de la labor regia, su acción casi de resurrección para con la vida del reino.

Tras referir el encargo que efectuó Carlos IV a la Real Academia de la Historia en $1794^{56}$, comienza el volumen a relatar una pormenorizada Historia de la legislación castellano-leonesa, partiendo, como no podía ser de otra forma, de la legislación gótica, base de la constitucion política, civil y criminal de Castilla, para enlazar con Fernando III y Alfonso X, por medio del Fuero Juzgo, cuya autoridad es extendida por padre e hijo, antes de afrontar una obra jurídica original, que ocupa el nervio central del libro ${ }^{57}$. Comparecen los reyes visigodos, los asturianos, los leoneses, los condes de Castilla y los titulares de la Corona unida: fue propiamente un reyno gótico, se afirma sin tapujos a lo largo de su secular existencia, incluso en ausencia de godos. Se habla con exagerada erudición de los fueros (no sólo los castellano-leoneses) y demás complementos jurídicos medievales surgidos alrededor del texto gótico, así como de sus defectos y vicios, en una línea de contenida crítica, con un parecer no abiertamente confrontado u opuesto a tales cuerpos, por cuanto que conformaban las semillas del modelo constitucional patrio. Se van desgranando los principales textos (especialmente, Cortes de Nájera, Fuero de Burgos, alvedrí, fazañas y Fuero Viejo) y las principales instituciones, tributos, regalías y jurisdicciones recogidas en los mismos, explicando, en suma, el funcionamiento del Derecho castellano-leonés contenido en los diferentes fueros con una descripción de sus variedades en lo público y en lo privado, en lo patrimonial, en lo personal y, sobre todo, en lo familiar. El padre de familia y la familia misma constituyen el más importante legado que han dejado los fueros desde el punto de vista social. La base de nuestro modelo político parece estar allí. Pero esa familia no ha permanecido en una situación de solipsismo, sino que ha logrado salir de sí misma y vincularse con otras familias, creando instancias intermedias, entre las que destacan los municipios o concejos. La Nación es la suma de aquellos padres de familia, conforme a la Constitución municipal, que han vivido desde tiempos medievales con arreglo a los esquemas personales y patrimoniales diseñados en esos venerables textos, formando auténticos cuerpos políticos bajo forma municipal que se yerguen como sostén mismo del reino. Nunca se comportan de forma autónoma. Esa Constitución gótica y municipal se acaba por encajar en un uni-

\footnotetext{
${ }^{56}$ Cfr. F. Martínez Marina, Ensayo histórico-crítico, ed. cit., no 13-16, pp.13-16, con listado de obras alfonsinas, en $n^{\circ} 11$, pp. 9-11.

${ }^{57}$ Cfr. F. Martínez Marina, Ensayo histórico-crítico, ed. cit., nº 18-289, pp. 16 ss.
} 
verso superior que es la Monarquía, la cual funciona como si fuese una gran familia a su vez, que acoge a todos esos cuerpos políticos primarios, les da unión y, por medio de la unión, les da pleno sentido. Persiste siempre la centralidad monárquica, verdad incontestable de todos esos tiempos pasados, pero una entidad monárquica moderada o templada, no despótica, ni arbitraria, que se ha sometido desde siempre el impulso pacificador del Derecho. A su lado, una cantidad variable de Leyes Fundamentales, la más relevante de las cuales exigía congregar la nacion ó los principales brazos del estado que la representaban, para deliberar en común sobre los asuntos graves en que iba el honor y la prosperidad pública, cuyo ejemplo máximo son los Concilios visigodos y las Cortes generales castellanas, sin autoridad legislativa, pero con el derecho consolidado para representar y suplicar, para consultar y aconsejar al rey, recordarle sus obligaciones respetuosamente, y exponerle agravios con el objeto de obtener pronta reparación. Un modo de representación antiguo, nunca moderno, salvo cuando las ciudades hacen su aparición y se divisa un horizonte de pacto político y un consecuente derecho de representación. La revitalización de la Monarquía a la altura del año 1808, cuando varias crisis la atenazaban y casi anulaban, pasaba imperativamente por requerir un nuevo acuerdo entre el rey y el reino y para ello jugaban un papel destacado las ciudades en cuanto que expresión de esa Nación soterrada compuesta por padres de familia y familias mismas, en los que estaban depositadas las esencias ancianas de un modo de ser político que se tenía que defender y al que se tenía que volver una y otra vez, convencidos como estaban de que ése era el mejor modelo imaginable para el reino. Ahí está radicada esa Constitución gótico-municipal, esa unión del rey con el cuerpo político que formaba el reino, superior a cualquier gobierno feudal europeo de la época que, sin embargo, es incapaz de subsistir ante múltiples enemigos y amenazas: una de ellas es la cuestión sucesoria, vislumbrada ya entonces como vértice de todo el reino en cuanto que estructura política consolidada y duradera, pero también la emergencia de un poder señorial que confunde potestades y patrimonios. Va siendo alterada paulatinamente la vieja Constitución gótica, pero sin echarla a perder de modo irremisible. Todavía es reconocible, es perceptible, no obstante los cambios de calado operados, aunque los acontecimientos precipitan su crisis, su ruina, su decadencia.

Excesos, desórdenes, querencia a la anarquía, al particularismo y a la envidia, la falta de Derecho, particular en algunas localidades y general en el reino, crueldad y dureza de sus sanciones, alteraciones políticas y discordias civiles, guerras, con un panorama final de ausencia de Justicia y de orden jurídico en suma, provocan la necesaria y saludable reacción regia, todo lo cual fuerza a los monarcas a actuar ${ }^{58}$. Pri-

\footnotetext{
${ }^{58}$ Cfr. F. Martínez Marina, Ensayo histórico-crítico, ed. cit., no 288-289, pp. 240-241, con tintes apocalípticos: "A los vicios y desórdenes de la constitucion civil y criminal, hay que añadir los que se siguiéron de las grandes alteraciones políticas y discordias civiles ocurridas en el reyno despues de la muerte del emperador Alonso VII á consecuencia de su mal acuerdo y desacertado consejo de partir el reyno y dividir el cetro entre sus dos hijos Sancho y Fernando. La diferentes y aun opuesta condición y genio de
} 
meramente, Fernando III (trayendo a colación la leyenda de los doce sabios y el Setenario), brevemente bosquejado, y luego, por supuesto, Alfonso El Sabio, hacen su aparición estelar. Ambos son responsables de esa búsqueda de la felicidad de los vasallos, idea con cierto regusto al siglo XVIII, para extirpar injusticias y violencias e introducir orden y subordinación con el objeto de dar vigor a las leyes. Uno, el padre, comparece como ideólogo; el otro, el hijo, como efectivo ejecutor de ese proyecto que buscaba anular las leyes antiguas, seleccionar las mejores y más equitativas de todas las contenidas en los fueros municipales, y formar con ellas un cuerpo legislativo común, general, acomodado a las circunstancias, y redactado en castellano ${ }^{59}$. Tras hablar de Espéculo y Fuero Real con cierto laconismo ${ }^{60}$, nos sumerge en Partidas, describiendo sus códices y autores directos en abierta colaboración con el rey, sin que cesen los elogios en una línea ya conocida y estilada de modo abundante por

estos príncipes, la guerra en que desde luego se empeñaron contra el navarro; la imprevista y acelerada muerte del rey don Sancho; su disposicion testamentaria en órden á la tutela de sus hijo el infante don Alonso y á la gobernacion del reyno,; el peso de la administracion pública descansando sobre los hombros de un solo ciudadano, y el rey niño sujeto en esta edad flaca y deleznable al arbitrio de un caballeros particular; las ambiciosas pretensiones de los grnes, las inquietudes y turbaciones de los POnces, Haros y Azagras, las parcialidades de los Castros y Laras; una guerra civil encendida y continuada tenazmente entre los monarcas leones y castellano, las desavenencias de los dos reyes Alfonso VIII y IX de este nombre entre sí mismo y con los príncipes cristianos sus vecinos: esta cadena eslabonada de tan desgraciados sucesos produxo un trastorno general en el estado, excitó violentos torbellinos, bravas y furiosas tormentas que expusiéron mas de una vez el reyno cristiano á su total desolación. Entónces se viéron enervadas las excelentes leyes municipales de que atrás hicimos memoria, violados los solemnes y religiosos pactos de poblacion; descantilladas y rotas las basas y columnas de la propsperidad municipal; la autoridad de los comunes oprimida, la vara de la justicia depositada en manos de la indómita é incorregible juventud; como en manera de queja dixo el santo rey don Fernando segun el testimonio que nos dexó su hijo el infante don Alonso en el libro Setenario: Fincaba todo el fecho en mancebos de poco seso et de mal entendimiento; ca entendien el mal por bien et el tuerto por derecho. Y añade: Que erraban por siete cosas: por mancebía, por desentendimiento, por mal consejo, por olvidanza, por non recebir castigo, por vileza, por desmesura". Para continuar: "De aquí una furiosa avenida de crímenes y males derramó por todas partes el desasosiego, la turbacion y el espanto. En las ciudades, villas y lugares, en poblado así como en desierto, se cometian y fraguaban mil injusticias, violencias, robos, latrocinios y muertes: cada paso era un peligro, y los facinerosos se multiplicaban en tal manera y obraban tan á su salvo, que si bien muchas leyes criminales eran así crueles como diximos, todavía don Alonso IX tuvo que inventar otras mas acervas, crudas y sanguinarias, mandando, según dexó escrito el Tudense, que los ladrones y enemigos del reposo de la republica fuesen precipitados de las torres, otros sumergidos en e mar, otros ahorcados, otros quemados, otros cocidos en calderas, y otros desollados y atormentados de varias maneras, á fin de que el reyno se conservase en paz y justicia que deseaba. Tal era el semblante que presentaban las cosas de la monarquía mediado el siglo XII, mejorado en parte á fines del mismo siglo y principios del siguiente, á la muerte de Alfonso VIII".

${ }^{59}$ Cfr. F. Martínez Marina, Ensayo histórico-crítico, ed. cit., no 290-292, pp. 241-244.

${ }^{60}$ Cfr. F. Martínez Marina, Ensayo histórico-crítico, ed. cit., n ${ }^{\circ}$ 293-300, pp. 244-250, para Espéculo; y no 301-302, pp. 250-254, para el Fuero Real, del que se dice "excelente cuerpo legal, breve, claro, metódico, comprehensivo de las leyes mas importantes de los fueros municipales, y acomodado á las costumbres de Castilla y al Fuero-juzgo, cuyas decisiones copian muchas veces literalmente". 
los ilustrados ${ }^{61}$. Pero también la obra del Rey Sabio debe ser valorada en su justa medida y en sus justos términos para saber exactamente ante qué nos hallamos: no es una obra original de jurisprudencia, ni fruto de meditaciones filosóficas sobre los deberes y mutuas relaciones de los miembros de la sociedad civil, ni sobre los principios de la moral pública adaptados a la naturaleza y circunstancias de la Monarquía. Martínez Marina desnuda el cuerpo normativo alfonsino de forma drástica y con crudeza: es una redacción metódica de las Decretales, Digesto y Código de Justiniano con algunas adiciones tomadas de los fueros de Castilla, de suerte tal que asi considerado con relación á las leyes civiles y materiales que comprehende, no puede tener mas mérito que las fuentes mismas de que dimana ${ }^{62}$. Lo cual no impide juzgar positivamente el empeño del Rey Sabio en una época, como la suya, tan alejada de la sabiduría y de las sutilezas que implicaba el conocimiento científico del Derecho compilado en la obra de Justiniano. A pesar de los oscuros tiempos en los que vive, Alfonso decide dar a Castilla y León la mejor legislación, de forma atrevida, digna de un príncipe filósofo y superior á su siglo, para lo que se rodea de los mejores jurisconsultos dispuestos a realizar un excelente código nacional con celo, laboriosidad y exquisita erudición. Ninguna sociedad medieval puede presentar un texto de tales caracteres, ni por aproximación. Lo fue en su época y lo fue con el paso del tiempo Es más: las sociedades modernas pueden aún consultar con aprovechamiento los textos alfonsinos que conservaron estima y reputacion, tanto que se miraron en los pasados siglos así como en el presente, no solo con el aprecio y acatamiento que se merecen en calidad de cuerpo legislativo nacional autorizado por el gobierno, y que comprehende en gran parte la actual constitucion politica, civil y criminal del reyno, sino tambien consideradas como una obra de gusto y erudicion. Se leen porque obligan, pero asimismo por el gran trabajo estético o artístico que Alfonso dirigió en su momento: se leen también porque gustan, porque enseñan y porque deleitan. Es un compendio que interesa al jurista, al filósofo y al literato por igual, dado que está escrita con magestad y elegancia, lenguage puro y castizo, con admirable órden y método en todas su partes principales, tanto que excede en esto y se aventaja sin duda alguna á los mismos originales; y se halla sembrada de noticias históricas muy curiosas, y de pensamientos filosóficos, y de máximas de profunda sabiduría dignas de consultarse y meditarse por nuestros políticos y legisladores ${ }^{63}$.

Hecho el elogio preliminar, viene de inmediato la crítica rotunda, severa, drástica, dirigida a encuadrar las Partidas en su lugar correspondiente, tanto en el fondo como en la forma. No obstante lo anterior, una idea subyace a ese afán hipercrítico: salvar el legado alfonsino y el buen nombre del rey. Respecto a las tachas de esa magna obra jurídica, la responsabilidad no corresponderá al rey, sino a los compiladores,

\footnotetext{
${ }^{61}$ Cfr. F. Martínez Marina, Ensayo histórico-crítico, ed. cit., no 303-319, pp. 254-271.

${ }^{62}$ Cfr. F. Martínez Marina, Ensayo histórico-crítico, ed. cit., no 319, pp. 270-271.

${ }^{63}$ Cfr. F. Martínez Marina, Ensayo histórico-crítico, ed. cit., no 320, pp. 272-273.
} 
ajenos a la tradición nacional en su mayor parte. A ellos y sólo a ellos son imputables las imperfecciones, vicios y defectos del siglo en que se escribieron, resultado de trasladar al lenguaje castellano el caudal romano-canónico, a saber, prolixos y pesados razonamientos; investigaciones importunas y mas curiosas que instructivas; decisiones inexactas y diminutas, y á su consecuencia obscuridad y confusion en algunas leyes $^{64}$. No obstante la advertencia del propio Alfonso X en P. 1, 1, 4, sobre cómo debe ser las leyes (sencillas y claras por encima de cualquier otra consideración), otros defectos se fueron sumando a los anteriores:

(...) esa multitud de preámbulos inútiles; fastidiosa y monotona division de leyes á la cabeza de todos los títulos; infinitas etimologías, unas superfluas y otras ridículas; exemplos y comparaciones pueriles ó poco oportunas; errores groseros de fisica é historia natural; amontonamiento de textos de la sagrada Escritura, santos Padres y filósofos; citas de autoridades apócrifas; doctrinas apoyadas en falsas decretales; empeño en juntar en uno, y conciliar derechos opuestos, derecho nacional y extranjero, eclesiástico y profano, canónico y civil, y de aquí determinaciones á las veces contradictorias, otras incomprehensibles, y doctrinas tan poco uniformes, y en ciertos casos tan confusas, que seria bien difícil atinar con el blanco del legislador y de la ley ${ }^{65}$.

La explicación a esta cascada de críticas es evidente y se deriva también de la perspectiva antirromanista típica de ciertos sectores ilustrados, con exención de responsabilidad del monarca y concentración de culpas entre los redactores del texto, pero con una dramática consecuencia final, cual es la alteración de la Constitución plurisecular de los reinos con efectos de todo punto imprevisibles:

En fin nuestros doctores, como si fueran extrangeros en la jurisprudencia nacional, é ignoraran el derecho patrio y las excelentes leyes municipales, y los buenos fueros y las bellas y loables costumbres de Castilla y Leon, y olvidándose o desentendiéndose de la intención del soberano, que siempre deseó conservar en su nuevo código los antiguos usos y leyes en quanto fuesen compatibles con los principios de justicia y pública felicidad, y no conociendo otro manantial, ni mas tesoro de erudicion y doctrina civil y eclesiástica que las Decretales, Digesto y Código, y las opiniones de sus glosadores, introduxéron en las Partidas la legislacion romana y las opiniones de sus intérpretes alterando y aun arrollando toda nuestra constitucion civil y eclesiástica en los puntos mas esenciales con notable perjuicio de la sociedad y de los derechos y regalías de nuestros soberanos $^{66}$.

\footnotetext{
${ }^{64}$ Cfr. F. Martínez Marina, Ensayo histórico-crítico, ed. cit. no 321, p. 272.

${ }^{65}$ Cfr. F. Martínez Marina, Ensayo histórico-crítico, ed. cit., no 321, pp. 272-273.

${ }^{66}$ Cfr. F. Martínez Marina, Ensayo histórico-crítico, ed. cit., no 321, p. 273.
} 
A continuación se explica el contenido de cada Partida y se glosan sus aciertos y sus errores precisamente a partir de los parámetros valorativos explicitados con anterioridad, es decir, cuanta mayor sea la proximidad al modelo tradicional castellanoleonés, a los antiguos fueros y costumbres, más positivo será el enjuiciamiento del texto y viceversa: a mayor alejamiento, mayor dureza y contundencia en la crítica, si bien salvada por la imputación de tales desmanes, errores, desvíos y traiciones para con el espíritu nacional a los juristas alfonsinos y no al propio rey, que conserva intacto su prestigio como monarca sabio.

Así, la Partida Primera es censurada porque opone al Derecho canónico nacional un Derecho canónico extraño, el extraído de las Decretales, privando a los monarcas españoles de muchas regalías dirigidas a la defensa y protección de la Iglesia, y otorgando amplios poderes, por el contrario, al Papado. La Iglesia hispánica pasa a regirse por un Derecho ajeno y diverso al hasta entonces conocido y empleado, lo cual quiebra la tradicional configuración de la Monarquía como protectora superior de la clerecía y la estrecha unión entre ambas instancias ${ }^{67}$. En el caso de la Partida Segunda, la que contiene la Constitución política y militar del reino, la percepción cambia: precioso monumento de historia, de legislacion, de moral y de politica, es sin discusión la parte más acabada de todas las que componen la obra alfonsina, por su gravedad y elocuencia, por las excelentes máximas filosóficas, y, sobre todo, por su íntima conexión con las antiguas costumbres, leyes y fueros municipales o generales de Castilla y León, de las quales por la mayor parte está tomada. Ahí está su mayor y mejor acierto, lo que confirma el criterio valorativo del canónigo asturiano. Todo el mundo debe leerla: juristas, políticos, literatos, reyes, grandes, caballeros y nobles ${ }^{68}$. Pero no es texto perfecto, si bien se atenúa ese perfil negativo. Los errores son disculpables y sus efectos no tan dramáticos como en otras partes del texto alfonsino: hay cosas, asuntos y temas que deberían haberse evitado, como cierta prolijidad en la parte moral, la acumulación de autoridades y textos, las citas a la legislación extranjera, la brevedad y la concisión de algunas leyes con sus consecuencias de oscuridad, confusión y posibilidad de interpretaciones opuestas a los deseos de los reyes, con abierto cuestionamiento de su autoridad. Algunas modificaciones introducidas en contra del sentido tradicional de nuestra Constitución (en relación a la guarda del rey, a su tutela y a la regencia del reino, o al derecho de representación, por citar varios ejemplos señeros) son mostradas como pruebas de los riesgos y fracturas que provocan tales innovaciones, absolutamente carentes de amparo o de fundamento a la luz de nuestra tradición jurídico-constitucional, lo mismo que acontece con la inalienabilidad del patrimonio del reino. Todo ello se ve acompañado con la única forma posible de justificación del legado pretérito frente a las innovaciones normativas del monarca: la erudición histórica, con noticias de todo tipo respecto a comportamientos ejemplares -y no tanto- de los reyes a modo

\footnotetext{
${ }^{67}$ Cfr. F. Martínez Marina, Ensayo histórico-crítico, ed. cit., no 322-364, pp. 273 ss.
}

${ }^{68}$ Cfr. F. Martínez Marina, Ensayo histórico-crítico, ed. cit., no 365, p. 311. 
de forma singular de explicación o construcción de la tradición y de demostración cumplida de que ésta había funcionado y merecía seguir funcionando. La narración expone lo anciano y lo nuevo, ligando a lo primero ventajas y beneficios, y vinculando a lo segundo todos los conceptos opuestos. La Constitución está así redactada y así ha venido funcionando con regularidad ${ }^{69}$. En la Partida Tercera, cambia la percepción ante la insuficiencia del Derecho de los fueros en materia procesal. Fue elaborada con bello método recogiendo lo mejor y más estimable del Digesto, Código y Decretales, y entresacando lo poco que se halla digno de aprecio en nuestro antiguo derecho, para servicio del rey y del pueblo, tratándose de una obra nueva y completa, pero no exenta de críticas en algunos extremos, como el que se refiere a los letrados y abogados, auténtica lacra del sistema jurídico del Antiguo Régimen ${ }^{70}$. Crítica que se reitera en relación a la Partida Cuarta por los motivos ya conocidos: Los colectores de este libro, olvidando ó ignorando las costumbres de Castilla, las excelentes leyes del código gótico, y las municipales derivadas de él; y acudiendo siempre á buscar en legislaciones extranjeras quanto necesitaban para llenar su plan, formaron una copilacion, en que apenas se conserva de lo antiguo otra cosa mas que los nombres, y aun muchos de ellos representan aquí ideas diferentes, lo que da como resultado el caos legislativo, un sistema misterioso e incomprensible, consecuencia de agrupar leyes opuestas e inconciliables $^{71}$. Lo mismo acontece, aunque el tono de reproche es más moderado y matizado, en relación a la Partida Quinta y a la Partida Sexta, a las que se tilda de piezas bastante acabadas, que forman un bello tratado de legislacion por ser usualmente las leyes romanas en ambas materias conformes a la naturaleza y a la razón, lo que supone crear otro patrón valorativo, además del castellano ya indicado, en este caso conformado por un Derecho racional, es decir, por el Derecho natural (se sobreentiende que natural y cristiano), el cual se encuentra en la misma legislación romana que antes se criticaba, pero que ahora se ensalza no por sí misma, sino por su concordancia con esos principios inmutables y eternos que se hallan en su base ${ }^{72}$. La Partida Séptima sigue esta misma línea valorativa: texto loable que mejoró la jurisprudencia criminal de los fueros municipales, hermoso en su factura, copioso en su contenido, bien ordenado, aunque mejorable, lo cual podría haberse hecho siguiendo el código gótico y los fueros municipales en algunas determinaciones más equitativas y regulares $^{73}$. La parte que resta de la obra de Martínez Marina se ocupa de las cuestiones referidas a la vigencia, oficial y oficiosa de las Partidas, así como a las modificaciones en tiempos intermedios, hasta arribar al siglo XVIII, y a las ediciones más relevantes, desviándose, por ende, de la temática central hermenéutica hasta ahora desarrollada ${ }^{74}$.

\footnotetext{
${ }^{69}$ Cfr. F. Martínez Marina, Ensayo histórico-crítico, ed. cit., no 366-375, pp. 311-320.

${ }^{70}$ Cfr. F. Martínez Marina, Ensayo histórico-crítico, ed. cit., no 376-393, pp. 321-334.

${ }^{71}$ Cfr. F. Martínez Marina, Ensayo histórico-crítico, ed. cit., no 394, p. 334.

${ }^{72}$ Cfr. F. Martínez Marina, Ensayo histórico-crítico, ed. cit., no 398-405, pp. 336-344.

${ }^{73}$ Cfr. F. Martínez Marina, Ensayo histórico-crítico, ed. cit., no 406-411, pp. 344-349.

${ }^{74}$ Cfr. F. Martínez Marina, Ensayo histórico-crítico, ed. cit., no 412-486, pp. 349 ss.
} 
El castellanocentrismo de Martínez Marina es, pues, claro y concluyente. La dependencia enorme respecto del Derecho Común lastra algunas partes del cuerpo alfonsino, no su totalidad por lo que sigue sirviendo como depósito principal de la Constitución de los reinos; pero hay ciertas taras insoslayables, lo cual es el efecto directo de la acción arbitraria de los compiladores que la redactaron, en ningún caso del rey, que sale absuelto del juicio de la Historia, entre otras cosas, porque sus deseos fueron explicitados en el propio cuerpo normativo. La crítica de los juristas es asimismo una crítica subrepticia a todo el mundo de los letrados que vivían por y para un aparato judicial lento, complejo y farragoso, a todo ese mundo profesional convulsionado por el nuevo tiempo que auguraba cambios radicales en la conformación del orden jurídico, lo que implica una cierta anticipación para la clausura de los tiempos del Derecho Común, aunque el remedio no se da en clave racionalista, sino historicista, no por medio de un Código nuevo, sino por medio de una mejor recopilación de lo ya existente. La validación de la obra de Alfonso X se realiza a partir de su concordancia o no con la Constitución tradicional gótico-municipal de Castilla y León, sin tomar en consideración su perfección técnica o su capacidad de innovación. Las normas alfonsinas son más perfectas cuanto más se aproximen al modelo gótico-medieval y son más criticables cuanto más se aparten de esa tradición castellana. La Historia está llena de ejemplos de lo uno y de lo otro: la conservación del pasado implica calma, tranquilidad, orden, paz; la perturbación del mismo mediante cambios radicales trae consigo la disensión, la discrepancia, el desorden, la contienda, la guerra. Indiscutiblemente, en las Partidas, hallamos Leyes Fundamentales, pero no leyes perfectas. Su imperfección se percibe por el mero hecho de alejarse del camino trazado por la Historia, es decir, cuando se abandona el caudal godo y municipal, donde se halla la esencia de nuestro modelo político. Cedieron al empuje cultural del momento, con renuncia a las esencias patrias, al pasado más inmediato. Esta separación, alejamiento o abandono no tuvo lugar por impulso del rey, sino por obra de los doctores que actuaron como si fuesen extranjeros e ignoraron el Derecho patrio, los fueros, las costumbres y los usos inmemoriales de la Corona castellano-leonesa. En contra de los propósitos del rey, la obra no llegó a buen puerto y no logró ni la unidad normativa, ni domeñó a la nobleza, que siguió campando a sus anchas, disfrutando de privilegios feudales por encima de la racionalidad normativa monárquica. No dio sus frutos y la pluralidad normativa siguió siendo la regla general en la Corona de Castilla y León, algo no muy diferente a lo que acontecía en los años en que Martínez Marina escribía. De ahí, el final del Ensayo auspiciando un nuevo tiempo normativo, con crítica hacia la Novísima Recopilación incluida ${ }^{75}$. La conclusión era clara: de la

\footnotetext{
${ }^{75}$ Cfr. F. Martínez Marina, Ensayo histórico-crítico, ed. cit., no 458, pp. 399-400: "Desde luego reconocen [literatos y jurisconsultos sabios] en la Recopilacion, el primero, el mas importante y necesario, defectos incorregibles por su misma naturaleza: obra inmensa y tan voluminosa que ella sola acobarda á los profesores mas laboriosos: vasta mole levantada de escombros y ruinas antiguas: edificio monstruoso, compuesto de partes eterogéneas y órdenes inconciliables: acinamiento de leyes antiguas y modernas,
} 
misma manera que Alfonso X había fracaso en sus propósitos uniformadores, también la realeza coetánea, de modo sucesivo, había naufragado en el intento de crear un orden jurídico claro, sencillo y preciso. El enjambre legislativo y jurisprudencial español seguía en plena actividad siglos después. Debía efectuarse una reforma radical que la Novísima no había ni previsto: ante el caudal de defectos e imprecisiones, de errores y de incorrecciones, era más sencillo elaborar un nuevo cuerpo legislativo que corregir el ya existente. La obra alfonsina servía en su inmensa mayoría, pero tenía que ser modificada en ciertos puntos. Una reforma no de futuro, sino de pasado, es decir, consistente en eliminar las excrecencias detectadas en tiempos anteriores para superarlas, para erradicar aquello que hacía inauténtica tal obra por contraria el espíritu nacional castellano: buscar el viejo y buen Derecho, recuperar la antigua Constitución gótica y municipal, por medio del estudio, profundizar en la obra de Alfonso $\mathrm{X}$, para dar como resultado algo rotundamente nuevo, pasando por encima de la misma y contemplando la posibilidad de ordenar, derogando o abrogando. Políticos y juristas han de actuar principalmente, aunque de forma diversa a los historiadores, y han de superar los estrechos márgenes por donde estos se movían, pero siempre a partir de sus conocimientos, buscando los efectos de la restauración y de la mejora:

Así que creen los doctos que para introducir la deseada armonía y uniformidad en nuestra jurisprudencia, dar vigor á las leyes y facilitar su estudio, de manera que las pueda saber á costa de mediana diligencia el jurisconsulto, el magistrado, y aun el ciudadano y todo vasallo de S. M. según que es derecho del reyno: conviene y aun tienen por necesario derogar nuestras antiguas leyes y los cuerpos que las contienen, dejándolos únicamente en clase de instrumentos históricos para instruccion de los curiosos y estudio privado de los letrados; y teniendo presentes sus leyes formar un código legislativo, original, único, breve, metódico; un volumen comprenhensivo de nuestra constitucion política, civil y criminal; en una palabra, poner en execucion el noble pensamiento y la grandiosa idea que se propuso don Alonso el Sabio quando acordó publicar el código de las siete Partidas ${ }^{76}$.

publicadas en diferentes tiempos y por causas y motivos particulares, y truncadas de sus originales, que es necesario consultar para comprender el fin y blanco de su ublicacion".

${ }^{76}$ Cfr. F. Martínez Marina, Ensayo histórico-crítico, ed. cit., $n^{\circ} 358$, p. 400. Párrafo que pone fin a su Juicio Crítico de la Novísima Recopilacion. Por el ciudadano D. Francisco Martínez Marina, Canónigo que fue de la iglesia de San Isidro de Madrid, y actualmente de la de Lérida, Individuo de número de las Academias Española y de la Historia, y de las buenas letras de Barcelona, y Diputado en las actuales cortes por el Principado de Asturias. Madrid, 1820, pp. 334-335. En su Teoría de las Cortes, ed. PérezPrendes, Tomo I, precedida del Discurso Preliminar, ${ }^{\circ}$ 102, p. 111, se puede leer a propósito del Ensayo: "Me propuse por objeto principal de aquella obra trazar un cuadro de nuestras antiguas instituciones y de las leyes mas notables de los cuadernos y códigos nacionales con sus luces y sombras a fin de promover la reforma de nuestra jurisprudencia y mostrar la absoluta necesidad que había de la copilacion de un nuevo código civil y criminal. Tambien se han indicado en ella los medios adoptados por nuestros padres para conservar su independencia y las principales leyes fundamentales de la monarquia española 
La obra jurídica de Alfonso X, con todas las advertencias, objeciones y salvedades hechas, quedaba convalidada tras la estricta labor de crítica realizada por Martínez Marina. Servía para los tiempos actuales. Seguía siendo un pilar básico de nuestra Constitución, conteniendo numerosas Leyes Fundamentales en su interior, pero sin olvidar los defectos graves que aquélla rezumaba, sobre todo, el romanismo, en lo civil y en lo eclesiástico, la dependencia de la Roma secular y religiosa, rasgo acentuado de forma deliberada por sus compiladores, y la distorsión final ocasionada como consecuencia de esa invasión romano-canónica sin contemplaciones. La recomendación final era un acercamiento al modelo gótico-municipal de los primeros siglos medievales, donde estaba la Constitución en su forma pura, primigenia y original, liberando al cuerpo alfonsino de toda ese marasmo de texto romanos y canónicos, legales y doctrinales, que lo único que hicieron fue perturbar la clásica comprensión del modelo político castellano-leonés y lo corrompieron, haciéndolo inviable e irreconocible, y, por ende, ignorado y despreciado. Los numerosos ejemplos históricos muestran a las claras lo que sucedía cuándo se decidía prescindir de la Constitución histórica. Había que volver a la misma imperativamente para lo cual se podían emplear instrumentos normativos modernos. Nada hacía pensar que la obra legislativa de Alfonso $\mathrm{X}$ fuese eliminada, ni mucho menos. Mejorada y corregida, podía servir mucho tiempo más. Podía ser el punto de arranque de una indispensable renovación jurídica, siempre dentro de un molde clásico o conservador, en ningún caso rupturista o revolucionario. La suerte de su legado político, por el contrario, iba a ser otra muy distinta.

Andamos por el año 1813 y todo ha mudado ${ }^{77}$. En la Teoría de las Cortes, el tono cambia rotundamente y lo que eran advertencias y ajustes, mínimas objeciones y reproches, se convierten en dardos críticos muy afilados que van a la línea de flotación del reinado alfonsí. La general valoración positiva, no exenta de reproches controlados, y la exaltación del modelo tradicional con defensa de un tránsito hacia otras modalidades de formulación, expresión y presentación del Derecho bajo la forma de Código, dan paso a otros pareceres más duros en el campo político. Esta obra, junto con su Discurso sobre el origen de la Monarquía y sobre la naturaleza del gobierno español, del mismo año 1813 (inicialmente publicada de modo separado y luego incorporada

y de la antigua constitucion de Castilla, para que el público las conociese, y conociéndolas, hiciese de ellas el debido aprecio y suspirase por su restablecimiento y diese algun paso para mejorar de situacion". ${ }^{77}$ En el ínterin, Martínez Marina da a luz un texto que anticipa argumentos de la Teoría. Me refiero a su Carta sobre la antigua costumbre de convocar las Cortes de Castilla para resolver los negocios graves del reino. Londres, 1810, dirigida a Jovellanos, con examen detenido de las Cortes medievales y de sus vicisitudes, y empleo prolijo de Partidas y demás textos normativos castellano-leoneses sobre el particular. Se detiene la narración en tiempos de Carlos I, precisamente cuando comienza el despotismo ministerial y el trastorno de la Constitución. El autor está dando pie a la emergencia de un nuevo sujeto político, la Nación, cuya forma de expresarse son las Cortes, si bien no está nada claro y no se clarifica posteriormente en el mismo texto qué Nación tiene Martínez Marina en mente y cuáles Cortes actuantes en relación a la misma. Por eso mismo, la Teoría será un intento decidido para dar respuesta a ambas cuestiones y tratar de definir tanto a la primera como a las segundas. 
al texto principal), plena de escolasticismo y de sus paradigmas filosóficos, postula una visión política de la Historia hispánica en los siguientes pasos: un pacto visigótico fundacional, del que nace una Monarquía católica como forma política incontestable; y un consensualismo como vía de determinación de las principales normas jurídicas a través de Concilios, Curias y Cortes, lo que implicaba un funcionamiento regular de la representación nacional (con municipios y poderes urbanos), y coartaba de todo punto el despotismo patrimonial al que podía tender el rey. Como consecuencia de lo anterior, la Monarquía se diseña como forma de gobierno moderada, limitada, templada, con poderes regios y también políticos regnícolas en perfecto equilibrio. Rechaza Martínez Marina en todas sus formas el despotismo, tanto bajo la forma del rey tirano, como bajo la del reino feudal regido por señores laicos y eclesiásticos. La única posibilidad de salvación -y en esto el engarce con el Ensayo se antoja evidente- es la conservación de la representación municipal que es tanto como decir nacional, para frenar la fuerza expansiva de ese feudalismo tiránico y disgregador. Curiosamente el Discurso no habla para nada de Alfonso X, aunque sí de su padre, Fernando III, con quien se consolidan las Cortes medievales y comienzan a ser llamadas asi ${ }^{78}$. Pero, antes bien, al contrario, la reprobación de Alfonso es la regla general en el texto de la Teoría al que se acusa sin tapujos de déspota por influjo de aquellas ideas procedentes de allende los Pirineos de las que los juristas eran principales abanderados ${ }^{79}$. En relación al Consejo Real y en esta misma línea argumentativa, la acción del Rey Sabio fue abiertamente contraria a la Constitución política de sus reinos, por lo que al anterior calificativo se debe sumar el de anticonstitucional, lo que da pie a reiterar descalificaciones y hacer aparecer palabras temidas:

Sin embargo es preciso confesar que mediado el siglo décimotercio, y durante el reinado de D. Alonso el Sábio padeció mucho la constitucion de la monarquia, y fue en gran manera conturbada y menoscabada la autoridad del consejo. Bien conocido es en la historia el espiritu novador de este Príncipe, nadie ignora su profusion y prodigalidad y los esfuerzos que hizo para aspirar al gobierno absoluto, y cuántas veces osó atentar contra las costumbres, fueros y libertades nacionales: y acaso es el primero de los Reyes de Castilla á quien se pueda justamente aplicar el aborrecible y enojoso dictado de déspota. Pues aun cuando sus intenciones fuesen sanas, las ideas grandiosas, y las innovaciones meditadas muy sábias y ventajosas á la sociedad, todavía como le faltó la prudencia y el tino y el consejo y el debido miramiento con la nacion, y el respeto y acatamiento á las costumbres y leyes patrias, se hizo odioso á los pueblos y mereció perder el imperio y el mando, segun diremos mas adelante ${ }^{80}$.

\footnotetext{
${ }^{78}$ Cfr. F. Martínez Marina, Teoría de las Cortes, ed. cit. Tomo I, Discurso Preliminar, no 81-84, pp. 99-100.

${ }^{79}$ Cfr. F. Martínez Marina, Teoría de las Cortes, ed. cit. Tomo II. Cap. XVI, no 6-8, pp. 731-732: “D. Alonso el Sabio sin embargo de que su gobierno declinó demasiado al despotismo (...) No obstante imbuido este Príncipe en máximas antipolíticas y en las ideas de despotismo que los jurisconsultos españoles discípulos de las escuelas de Bolonia le habían sugerido (...)".

${ }^{80}$ Cfr. F. Martínez Marina, Teoría de las Cortes, ed. cit. Tomo II. Cap. XXVII, nº 16, pp. 871-872.
} 
Lo que antes eran simples defectos normativos, fruto de la influencia foránea, han dado paso a crímenes políticos esenciales, a atentados contra las bases fundamentales de la comunidad política, con modificación de esas leyes patrias. El rey abraza el despotismo y adquiere ese epíteto para la posteridad. Inicia una práctica reprobable: aspirar al gobierno absoluto, por lo que todos los frenos previos saltan por los aires y devienen inútiles. El rey viola el Derecho tradicional, actúa con marcada falta de prudencia y de tacto, sin asesoramiento, dando pie a un colapso personal e institucional, que se traduce finalmente en una ausencia de respeto a la Nación lo que justificará los posteriores castigos derivados de su mala conducta. No es el único que hace esto, pero sí el primero que inaugura una nómina continuada en la época moderna por los Austrias. Martínez Marina trata de salvar la tradición nacional y las dinastías locales, responsabilizando a los reyes extranjeros (fundamentalmente a Carlos I) del desmantelamiento y de los desmanes arbitrarios que se gestan desde el siglo XVI en adelante cuando aquella vieja Constitución histórica y sus pilares básicos caen, se desmoronan, para dar paso al más exacerbado despotismo monárquico y ministerial. Los Reyes Católicos, no obstante su profundo programa de reformas dirigido a superar el Medievo y crear una nueva forma monárquica más sólida, autoritaria y poderosa, quedan exculpados. Es más: los reyes de la casa de Habsburgo no imitaron la conducta de Isabel y Fernando en el sentido de corregir defectos del gobierno, introducir reformas y dar muestras de amor a la Nación y de respeto hacia su Constitución y leyes. Se comportaron, por contra, como depredadores, desentendiéndose de las obligaciones mas sagradas, sin miramiento á las costumbres, á la constitucion ni á las leyes del pais, solo trataron de disfrutar este patrimonio, de esquilmar esta heredad, de disipar sus riquezas, de prodigar los bienes y la sangre de los ciudadanos en guerras destructoras que nada importaban á la nacion ni por sus motivos ni por sus consecuencias. El despotismo era su guía de conducta y, por eso, fué necesario deprimir la libertad nacional, chocar con la constitucion y declarar guerra á las cortes, abatir su autoridad, apocar su influjo, entorpecer sus operaciones, y desacreditándolas preparar su destrucción ${ }^{81}$.

El discurso narrativo que Martínez Marina despliega en la Teoría es, pues, el que sigue: nacimiento gótico de las Cortes y, con ellas, de un gobierno conjunto y moderado, con cierto protagonismo, no excluyente, de la Nación; persistencia medieval de las prácticas y estilos visigodos recuperados, con algunos cambios derivados de los nuevos tiempos, hasta llegar a la anulación alfonsina, acompañada de un expresivo silencio de noticias históricas acerca de su reinado, salvo alguna cita erudita, algún hecho criticable, ciertos acontecimientos interesados (como el problema sucesorio o la referencia a las Cortes de Valladolid, del año 1282, como auténticas Cortes, a pesar de la ausencia del rey, lo que sirve de argumento presentista: no se olvide la fecha en que se está escribiendo la Teoría), o bien hechos asépticos con invoca-

${ }^{81}$ Cfr. F. Martínez Marina, Teoría de las Cortes, ed. cit. Tomo I, Discurso Preliminar, no 90, p. 103. 
ciones a textos suyos a modo de respaldo doctrinal de algunas afirmaciones. Los sucesores de Alfonso X recuperan el esplendor constitucional en su sentido originario, incluso lo reafirman, hasta tiempos de los Reyes Católicos, momento a partir del cual comienza una crisis derivada de su olvido u ocultación en los siglos XVI, XVII y XVIII, para dar paso a una recuperación o revivificación en 1810 que se formaliza con la Constitución de 1812. Recuperación o revivificación que implica una comparación de las antiguas prácticas con las coetáneas por medio de numerosos ejemplos y con variados saltos en el tiempo, es decir, un análisis simultáneo de las Cortes medievales y de las Cortes modernas, para enraizar las segundas en las primeras, para depositarlas en el pasado como manantial o fuente de todo poder, de toda autoridad, de toda legitimidad. Las Cortes gaditanas no eran más que la feliz resurrección de las antiguas Cortes medievales, con idénticos fines e idénticas competencias. Y con ellas se operaba la recuperada comparecencia de la otra gran protagonista de la Historia patria, una vez ocultada o desposeída la Monarquía, como era la Nación. Es a través de las Cortes resurrectas que se articula la propia resurrección de la Nación y no al revés, ante el silencio de una Monarquía secuestrada, un país invadido y una Constitución aletargada, anestesiada como resultado de siglos de ocultación, ignorancia e incumplimiento. La única forma de romper ese marasmo paralizador era dando voz al viejo cuerpo político que había formado parte indisoluble de las estructuras políticas hispánicas desde los orígenes mismos de la primitiva Constitución. La Nación tenía el imperativo deber de restablecer las viejas normas constitucionales con algunos ajustes mínimos que evitasen en el futuro complejas situaciones críticas como las que se estaban viviendo. Había, pues, una imposición de reconstrucción y, por ende, una negación de capacidad constituyente a esa Nación que debía fungir, a lo sumo, como poder reconstituyente, nada más y nada menos. La Constitución la haría la Historia, no la Nación. Es más: ya estaba hecha. Ésta la recibía de aquélla, la ordenaba y la fortalecía. Nada se había creado tras la crisis de marzo de 1808; se había restablecido el antiguo tracto constitucional interrumpido por siglos de despotismo, regio y ministerial, cuyo primer eslabón histórico era Alfonso X. Si jurídicamente éste pervivía mediante su obra en el siglo XIX, políticamente no había redención posible para él y ninguno de sus logros servía como ejemplo positivo. El pasado, real, inventado o recreado, de nuevo, servía como elemento de consolidación y refuerzo del presente en tiempos inciertos en los que no parecía existir ningún otro sólido asidero ${ }^{82}$.

Estos argumentos no fueron construcciones aisladas, ni discursos que cayeran en el vacío o en el olvido. Dieron frutos y fueron recordados, apoyados y reiterados por

\footnotetext{
${ }^{82}$ Cfr. supra en Parte Primera, nota $\mathrm{n}^{0} 78$, con la bibliografía allí recogida. Las mismas ideas presiden sus Principios Naturales de la Moral, de la Política y de la Legislación, redactados hacia 1824 y publicados casi un siglo después, en el año 1933. Especialmente, interesa el Tomo II. Principios Naturales del Gobierno Civil y Político. Caps. XVII y XVIII. Cito por la edición de J. Varela Suanzes. Oviedo, 1993. Tomo II, pp. 186 ss.
} 
mucho tiempo en el plano académico ${ }^{83}$, pero también fuera de las aulas universitarias para los instantes que inmediatamente habían de acontecer. Esa línea de Martínez Marina la percibimos en el anónimo autor de un escrito aparecido en Madrid a lo

${ }^{83}$ Para explicar la importancia que en su momento tuvo el Ensayo, es suficiente mencionar un testimonio coetáneo. Jovellanos, en carta a Lord Holland, de 2 de noviembre de 1808, exponía lo siguiente a propósito de la citada obra: "V. E. ha estudiado ya y conoce nuestra Constitución, cuanto la escasez de escritos acerca de ella permite conocer; pero puedo asegurarle que la conocerá más clara y ampliamente cuando haya leído la obra que por una señalada y alta providencia ha salido a luz en el tiempo que era más necesaria y podía ser más provechosa. Hablo del Ensayo histórico-crítico sobre la antigua legislación y cuerpos legales de los Reynos de León y Castilla, publicado por el Dr. Dn. Francisco Martínez Marina, donde $\mathrm{V}$. E. hallará, además de un rico tesoro de erudición escogida y recóndita, otro de máximas políticas y morales, tan luminosas, tan sólidas y tan firmemente expuestas que, de cierto, no se pudieran esperar en el tiempo y situación en que se escribieron; puesto que esta luz de libertad y independencia apareció entre nosotros en el mismo punto en que las tinieblas de opresión y abatimiento acababan de cobijar todo el continente español. Un ejemplar de tan preciosa obra destinaba yo para V. E., pero sabiendo que nuestro amigo Dn. Manuel Quintana me ganó por la mano en este buen deseo, tendré el honor de enviar en su lugar a V. E. por medio del Caballero Stuard un ejemplar de la nueva y correcta edición de Las Partidas hecha por la Academia de la Historia y para la cual fuera destinado el trabajo del Sr. Marina. Cfr. Cartas de Jovellanos a Lord Vassall Holland sobre la Guerra de la Independencia (1808-1811), con prólogo y notas de Julio Somoza García-Sala. Estudio preliminar de Silverio Sánchez Corredera. Oviedo, 2009. Tomo I. [J-II] (Jovellanos a Holland). Remitida en 2 de noviembre 1808 al caballero Stuard, en Aranjuez, pp. 93-94. Para la influencia de Martínez Marina a lo largo del siglo XIX y XX, baste citar la presencia de sus planteamientos, saberes, informaciones y noticias en buena parte de la producción historiográfica de los tiempos referidos, como la que sigue, sin ánimo exhaustivo: R. Ortiz de Zárate, Análisis histórico-crítico de la legislación española. Vitoria, 1844. Tomo I, pp. 117 ss.; J. M. Montalván, Examen histórico-filosófico de la legislación española. Madrid, 1845. Tomo I, pp. 133 ss.; A. Marichalar y C. Manrique, Historia de la Legislación y Recitaciones del Derecho Civil de España. Madrid, 1861-1862. Tomo II, pp. 477 ss.; y Tomo III, pp. 3 ss.; D. R. Domingo de Morató, Estudios de ampliación de la Historia de los Códigos españoles. $2^{\mathrm{a}}$ edición. Valladolid, 1871, pp. 187 ss.; J. Permanyer, Apuntes de Historia del Derecho español. Barcelona, s/f., pp. 219 ss.; J. M. Antequera, Historia de la legislación española. Madrid, 1874, pp. 231 ss.; S. Adame Muñoz, Curso histórico-filosófico de la legislación española. Madrid, 1874, pp. 92 ss., M. Barrio y Mier, Historia general del Derecho español. Madrid, s/f. Tomo III, pp. 91 ss.; J. Hinojosa Menjoulet, Introducción histórica al estudio del Derecho español. Granada, 1879, pp. 45 ss.; A. M. Fabié, Disertaciones jurídicas sobre el desarrollo histórico del Derecho sobre las bases del Código Civil y sobre la organización de los tribunales. Madrid, 1885, pp. 51 ss.; L. Moret y Remisa, Lecciones de Historia general del Derecho español. Madrid, 1892, pp. 219 ss.; y E. M. Chapado García, Historia general del Derecho español. Valladolid, 1900, pp. 438 ss. Línea que luego continúan en el primer tercio del siglo XX los principales tratadistas de nuestra Historia del Derecho (R. Altamira, S. Minguijón, G. Sánchez, R. Riaza y A. García-Gallo) hasta los años 50, cuando éste último plantea una revisión de la obra alfonsina. Para este nuevo momento, vid. J. L. Bermejo Cabrero, "García-Gallo ante la obra legislativa de Alfonso X", en Cuadernos de Historia del Derecho, no 18 (2011), pp. 163-191; y, como marco más general, J. Sánchez-Arcilla Bernal, "La obra legislativa de Alfonso X El Sabio. Historia de una polémica", en J. Montoya Martínez y A. Domínguez Domínguez (coords.), El scriptorium alfonsí. De los libros de astrología a las Cantigas de Santa María. Madrid, 1999, pp. 17-81 [trabajo asimismo aparecido en Revista General de Legislación y Jurisprudencia. III época. Año CL, 1 (enero-marzo, 2003), pp. 107-135; y 2 (abril-junio, 20039, pp. 267-297; y como "Estudio introductorio", en Alfonso X El Sabio, Las Siete Partidas (El Libro del Fuero de las Leyes). Introducción y edición dirigida por J. Sánchez-Arcilla Bernal. Madrid, 2004, pp. XIII-XXXVI]. 
largo del año 1810, titulado Discurso sobre la necesidad de una nueva legislacion para todas las provincias españolas, y sobre los medios para formarla, y debido a la pluma de un antiguo magistrado, según rezaba en su portada. Allí se propugna aceptar el pasado jurídico en su momento construido, glorioso y perfecto, pero con la posibilidad de una reforma con arreglo a los nuevos aires, caminando en la senda que había trazado el Código Civil francés, sin llegar a su radicalidad transformadora. Para depurar nuestro sistema de legislación, se debía restituir el justo y útil sistema de las Partidas, si bien mejorado y enriquecido con las reglas de la Filosofía y con un estilo conciso. El modelo sería el Código napoleónico, incluso anticipando algunas disposiciones para aplicar a España sus principios de forma directa ${ }^{84}$. Por su parte, en un tono de mayor discrepancia, J. Canga Argüelles oponía a la idílica contemplación de la obra alfonsina, hasta entonces predominante, una acerada descripción de esa defectuosa Constitución de Castilla, plena de errores y de vicios, provocados por el impacto del absolutismo exógeno, importado por los monarcas de la casa de Austria y por los Borbones, pero también derivados de la propia organización interna de las Cortes (con dependencia total del monarca para su reunión, irregularidad de sesiones y de composición, diversidad del número de convocados, corrupción de los representantes para favorecer lo ordenado en la Corte, secreto de las sesiones, imposibilidad de control por parte de las ciudades de la labor de sus procuradores, etc.), lo que daba como resultado un cuerpo político capitidisminuido, carente de la capacidad de influencia que presentaba en otros reinos peninsulares ${ }^{85}$. Sin perjuicio de lo cual, el asturiano se aproxima a Martínez Marina y a su tesis respecto al tratamiento de esos venerables cuerpos jurídicos ancianos (respeto y adoración, pero reforma de los mismos de cara a los nuevos tiempos que se avecinaban), aunque con línea de pensamiento y de actuación propia que lo separan del anterior: la que le lleva a quitar a las leyes alfonsinas la condición de Constitución de los reinos, algo que es genuino y exclusivo parecer del autor que ahora nos ocupa frente al criterio dominante en la Ilustración. Simplemente sirven las Partidas desde un punto de vista filológico, por su modelo de buen lenguaje, pero son extractos de las opiniones de filósofos antiguos, legislación romana, decretales pontificias, mezcla extravagante de libertad y de esclavitud, de sabiduría y de ignorancia, de bueno y de malo, y no componen la constitución política de España, a no querer confundir las ideas, para tildarlo finalmente de monumento grotesco e informe ${ }^{86}$. La valoración se resquebraja; introduce el legado alfonsino en bloque dentro de terrenos dubitativos y abiertamente cuestionados, una

${ }^{84}$ Cfr. Discurso sobre la necesidad de una nueva legislacion para todas las provincias españolas, $y$ sobre los medios de formarla, por un antiguo magistrado. Madrid, 1810, p. 24. Como desarrollo de esta pasión francófila, aquí en ciernes, y para lo que resta del siglo XIX, vid. C. Petit Calvo, "España y el Code Napoléon", en Anuario de Derecho Civil. Tomo LXI, fasc. IV (2008), pp. 1.773-1.840.

${ }^{85}$ Cfr. J. Canga Argüelles, Observaciones sobre las Cortes de España y su organizacion. Valencia, 1809.

${ }^{86}$ Cfr. J. Canga Argüelles, Reflexiones sociales, ó idea para la constitucion española que un patriota ofrece a los representantes de Cortes, por D.J.C.A. Valencia, 1811, pp. 3-4. 
vez que se produce la colisión entre los dos momentos históricos objeto de confrontación, entre las dos visiones acerca de la Historia y de la Política que van a verse abiertamente enfrentadas y de las que solamente una podía resultar vencedora. O lo pasado o lo moderno. Las dos no tenían cabida en los nuevos tiempos.

2.4. Rotundamente opuesto a estos pareceres historicistas, más o menos intensos y profundos, es el de J. Sempere y Guarinos, quien se presenta, ante todo, como un pensador moderno, no anclado en el Antiguo Régimen, verdaderamente liberal (a pesar de su decisionismo con tintes cuasi autoritarios) y, en cierta forma, revolucionario. Lo demuestra de manera meridiana porque ve en el pasado algo a superar y no a recuperar, es decir, que entiende el presente como algo que es resultado de la construcción deliberada y voluntaria efectuada por los hombres mismos que lo integran y no por sus antepasados, a los que no se vinculan de ninguna de las maneras posibles. Los hombres son directores de su tiempo y de su destino ${ }^{87}$. Sempere y Guarinos desmontará prácticamente uno por uno aquellos lugares comunes en torno a una Constitución histórica, tan inmutable como imperceptible, edificados con su pasmosa y abrumadora erudición por Martínez Marina, y planteará una enmienda a la totalidad a los argumentos del asturiano. Es su antítesis, aun compartiendo conocimientos históricos y devoción por Clío, pero expuestos y desarrollados en el caso de este jurista alicantino con un mayor rigor, más dosis de racionalidad y un marcado sentimiento político y constitucional, avanzado y progresivo, que está anunciando la Modernidad. Alfonso X es protagonista incidental y menor de algunos de los embates del jurista eldense, mucho más agudo y acertado en sus planteamientos que el canónigo de Oviedo, acaso por ese marchamo jurídico que preside su formación y su actividad profesional. Conoce mejor el Derecho y su realización práctica. Ese sesgo marca su forma de hacer Historia jurídica, más acentuada en esta dirección, la jurídica viva, que en la puramente histórica ${ }^{88}$. Se darán algunas noticias de Alfonso El Sabio (la

${ }^{87}$ Vid. R. Fernández-Carvajal, "La historiografía constitucional de Sempere y Guarinos”, en Revista de Estudios Políticos, $\mathrm{n}^{\mathrm{o}} 82$ (julio-agosto, 1955), pp. 61-95; J. M. Carretero Zamora, "La obra de Sempere y Guarinos en la génesis historiográfica de las Cortes tradicionales", en P. Fernández Albadalejo, y M. Ortega López (eds.), Antiguo Régimen y Liberalismo. Homenaje a Miguel Artola. 3. Política y Cultura. Madrid, 1995, pp. 71-79; J. Rico Giménez, De la Ilustración al Liberalismo (El pensamiento de Sempere y Guarinos). Alicante, 1997; e "Ilustración y liberalismo en la obra de Juan Sempere y Guarinos (17541830)", en Studia Historica. Historia Moderna, no 19 (1998), pp. 241-259; y, sobre todo, el documentado y exhaustivo trabajo de R. Herrera Guillén, Las indecisiones del primer liberalismo español. Juan Sempere y Guarinos. Madrid, 2007.

${ }^{88}$ Lo muestran con claridad algunas de sus obras en las que manifiesta ser un profundo conocedor de los complejos mundos del Derecho vigente en España, moviéndose con soltura y con solvencia por todos los cuerpos normativos coexistentes, sin hacer excepción de la variada legislación alfonsina. Historia y Derecho se dan la mano de forma magistral al servicio de este último con un marcado sentido práctico. Por ejemplo, cfr. su Historia del luxo, y de las leyes suntuarias de España. Madrid, 1788. Tomo I. Cap. VII, pp. 79 ss.; Policía de España acerca de los pobres, vagos, y mal entretenidos, en Biblioteca Española Económico-Política. Madrid, 1801. Tomo I. Cap. XIII, pp. 47 ss.; la Historia de los vínculos 
modificación de la ley sucesoria, por ejemplo) o la referencia a su reinado como arquetipo de período calamitoso, cuyas consecuencias irán más allá de su propio tiempo y alcanzarán a sus sucesores inmediatos (su reinado fue una continua serie de calamidades, dirá nuestro autor). Sempere y Guarinos plantea en su obra un discurso contrario al valor sempiterno de la Historia defendido por nuestros ilustrados, por lo que no puede encuadrarse con propiedad en ese grupo heterogéneo de pensadores que forman nuestro Siglo de las Luces. Es ya alguien diferente, que piensa de modo diverso, rompedor, nada romántico, ni afecto a la Ilustración. No habla para el siglo XVIII, sino para el siglo XIX. Su planteamiento es rupturista: no hay que recuperar la Historia, sino superarla, avanzar, dirigirse hacia una nueva situación política. Los defectos continuados y casi congénitos de la vida española solamente se podían sobrellevar caminando hacia delante y no refugiándose en el pasado, precisamente porque ese pasado no ofrecía ningún modelo aprovechable. Más cabal y centrado en su lectura de la Historia, menos exaltado y no tan entregado al servicio de la nueva causa nacional, de aquella Nación recuperada, Sempere y Guarinos deconstruye a Martínez Marina y prácticamente destruye sus argumentos más significativos de una manera radical, yendo a la línea de flotación del historicismo del que hacía gala el primero. Hace una Historia así más real y verídica, dirigida a romper las ataduras con el pasado y a permitir de esta manera al cuerpo político, a esa Nación emergente y resucitada, recuperar una libertad de la que hasta entonces estaba desposeído. Y esto lo ejecuta en el sentido indicado al aniquilar y hacer inútil aquella referencia clave que matizaba o condicionaba la capacidad de decisión de toda la Nación: la Historia misma. Era la única manera de sobrevivir y de avanzar decididamente en esos tiempos ambiguos y difíciles. Si se quería edificar un mundo nuevo basado en la libertad, construido a partir de lo que quería la Nación, sin restricciones y sin limitaciones, era preciso hacer explícita la ruptura con el pasado y librar a aquélla de toda atadura, en el sentido de negar cualquier entronque con lo pretérito que la coartase. Ello implicaba examinar lo que de aprovechable se podía encontrar allí. Si Martínez Marina veía en el pasado el origen de todo y el punto hacia el que había que volver como depósito de unas esencias políticas puras, perfectas e inmutables, Sempere y Guarinos lo contemplaba como algo superado en todos sus extremos, no aprovechable en lo más mínimo, descartable, totalmente desprovisto de enseñanza y utilidad algunas: era desorden, caos, anarquía, terrenos sobre los que no se podía edificar nada perdurable. Lo único que cuenta es el presente, el hoy, el ahora, y la decisión que se tome por los hombres que viven en ese momento histórico sin atenerse a la tradición, a la Religión o a la Historia, sin ningún tipo de restricción. No hay nada antes, ni importa, ni tiene relevancia. La Nación posee el poder suficiente para decidir su destino sin compromisos previos, ni condicionantes absolutos o relativos. No le sirve ningún otro complemento, salvo

y mayorazgos. Madrid, 1805. Cap. XII, pp. 167 ss.; o su Historia de las rentas eclesiásticas de España. Madrid, 1822, pp. 100 ss. 
ella misma. Para asegurar esto, hay que demostrar que precisamente no hay en la Historia nada que inspire o determine al nuevo gobierno, nada que le pueda servir de ejemplo o de modelo, nada que coaccione la amplia capacidad de decisión de la Nación. Si se hace esto, se afirmará esa libertad del elemento nacional porque se rompe el ligamen con un pasado que carece de fuerza vinculante y se disuelve el modo político ilustrado, esto es, aquella forma de hacer Política a partir de la Historia y contando siempre con ella. La Política, en una novedosa acepción y contexto, cobra pleno sentido: ya no es recuperación del pasado, sino ocupación del futuro. Si se demostraba que la Historia no servía y carecía de cualquier utilidad, si no había en ella nada recomendable, ni susceptible de ser recuperado, la Nación sería más libre al poder actuar sin vínculos de ninguna clase. Si se anulaba el principal valor o argumento del historicismo político (la Historia como enseñanza, modelo, ejemplo), no quedaba más remedio que acudir a la Nación y hacerlo además con plena confianza en ella y en su capacidad de regeneración del orden político. Sempere y Guarinos efectuará todo esto por partes, pero siempre con una coherencia ejemplar. Por eso, con acierto, se ha calificado su línea de pensamiento como un decisionismo antitradicionalista, aunando una concepción de lo político no auspiciada ni por el orden, ni por la norma, sino por la voluntad del poder, junto con una furibunda oposición, cuando no abierto enfrentamiento, a aquellas dependencias de lo pretérito ${ }^{89}$. Veamos ahora una selección de su pensamiento a partir de sus más relevantes obras sin agotar su inmenso legado.

En el año 1810, se publican sus Observaciones sobre las Cortes y sobre las leyes fundamentales de España, obra en la que postula abiertamente la ruptura con el pasado a partir de una relectura de las Cortes y de las demás piezas integrantes de la presunta Constitución histórica ${ }^{90}$. Contrariamente al pensar dominante en esos años de que España debía su felicidad y prosperidad a la excelencia de sus instituciones y prácticas políticas y religiosas, olvidadas y desestimadas, pero en proceso de restablecimiento, Sempere y Guarinos se aparta de esta dirección intelectual. Esas Leyes Fundamentales, esa Constitución histórica, no han existido más que en la mente de algunos pensadores. Agradables sueños de un honrado ciudadano, pero sueños y teorías ajenos a la verdad de la Historia, dirá con cierta gracia en referencia a la reconstrucción fantástica más hegemónica de su tiempo, la de Martínez Marina ${ }^{11}$. Todas aquellas leyes han ido cambiando a lo largo del tiempo en todos sus ramos y por decisión de los sucesivos monarcas, por lo que ese rasgo suyo de la inmutabilidad difícilmente se puede defender. La sucesión de la Corona, la inalienabilidad de su

\footnotetext{
${ }^{89}$ Cfr. R. Herrera Guillén, Las indecisiones del primer liberalismo español, ed. cit., pp. 267 ss.; y “Estudio preliminar", en J. Sempere y Guarinos, Historia de las Cortes de España. Edición y estudio preliminar por Rafael Herrera Guillén. Madrid, 2011, pp. LXXXIII-XC.

${ }^{90}$ Cfr. J. Sempere y Guarinos, Cádiz, 1812. 1. Observaciones sobre las Cortes y sobre las leyes fundamentales de España. 2. Memoria primera sobre la Constitución gótico-española. Edición y estudio de Rafael Herrera Guillén. Madrid, 2007, pp. 57-106.

${ }^{91}$ Cfr. J. Sempere y Guarinos, Historia de las Cortes, ed. cit. Cap. XXX, p. 156.
} 
patrimonio, los privilegios de la nobleza, los fueros y franquezas del Estado en general, la inmunidad y la jurisdicción eclesiástica, o las magistraturas, por poner varios ejemplos, difieren de sus originarios perfiles. No hay nada inmutable, ni nada intocable. Todo cambia y todo ha cambiado y además todo cambia y todo ha cambiado de acuerdo con la voluntad del detentador del poder político en cada momento histórico $^{92}$. Trayendo a colación a nuestro monarca, el propio Alfonso es un ejemplo o modelo negativo para todo esto, puesto que no sólo las modifica, no sólo muestra la inconstancia de tales Leyes Fundamentales, sino que además exhibe con desparpajo la facilidad con que se han encontrado razones para tergiversar todo el orden jurídico en todos sus extremos ${ }^{93}$. El predominio de España como potencia no se explica por la grandeza de su Constitución. Es el fruto de los matrimonios afortunados de algunos de sus príncipes, en cierta forma, de la casualidad y del azar, de lo efímero y de lo perentorio. España tiene que abandonar el pasado y construir el presente desde la razón, desde la racionalidad, que no había alcanzado a atisbar ningún pensador del momento, recluidos como estaban en reductos tradicionales o históricos. El dilema político que plantea es el triunfo de la voluntad general o el triunfo de la fuerza, pero nunca debe triunfar la Historia y, con ella, el Derecho que viene de su mano. Su discurso adopta, pues, un claro tono anti-histórico y anti-tradicional, que ni gustó a los absolutistas (que tenían una fe ciega en un monarquía tradicional, plenamente convencional), ni agradó a los liberales (que intentaron pasar por encima de la Monarquía para asirse a algo aún más poderoso que ésta: la Historia, a su servicio, parcial e interesada, embarcada en una labor de reconstrucción de otra Monarquía, la visigoda). No había tal perfección paradisíaca en la vieja Constitución gótica, que no fue gobierno mixto, ni contó con auténtica representación nacional ${ }^{94}$. Tampoco hay rastros

${ }^{92}$ Cfr. J. Sempere y Guarinos, Observaciones, ed. cit. Prólogo, pp. 59-60.

${ }^{93}$ Cfr. J. Sempere y Guarinos, Observaciones, ed. cit. V, pp. 95-96: "El cotejo y contradicción de aquellas dos resoluciones de un mismo soberano [se refiere a la discrepancia entre las Partidas y el testamento de Alfonso X por lo que toca al derecho de representación], reputado por el más sabio de todos los españoles, manifiesta bien claramente la inconstancia de las leyes más fundamentales y la facilidad con que se han encontrado siempre razones especiosas para tergiversar los derechos públicos y privados. El de suceder en la corona de España ha dimanado, como en todas las demás naciones, de dos títulos principales: la voluntad general del pueblo o la fuerza y la política de algunos conquistadores", siendo lo segundo lo más frecuente en nuestra Historia.

${ }^{94}$ Cfr. J. Sempere y Guarinos, Observaciones, ed. cit. I, pp. 64-65 y, especialmente, pp. 70 y 72: "Es, pues, innegable que la constitución gótico-española no fue un gobierno moderado y mixto de las tres especies particulares de monarquía, aristocracia y democracia, y que los concilios, si se quieren llamar cortes generales, no representaban a la nación ni se componían de personas encargadas de sostener los derechos de todos los ciudadanos, siendo unas juntas por la mayor parte eclesiásticas, convocadas por los reyes con el fin principal de afirmar su autoridad, por medio de la religión, que es la que más influye en el espíritu público de todos los pueblos, y con mucha mayor fuerza en los de aquella época, resabiados todavía de las antiguas preocupaciones germánicas (...) Así se fue formando la constitución gótico-española; así su código del Fuero Juzgo, mixto de costumbres e instituciones germánicas y romanas, y así los antiguos concilios mensuales formadas de toda clase de personas libres, vinieron a parar en unas 
de perfección en las feudalizantes Leyes Fundamentales que surgen en el Medievo, donde la nobleza adquiere un protagonismo de excepción en detrimento de la autoridad regia ${ }^{95}$. Siguen cambios en las Cortes en tiempos medievales con la irrupción de las ciudades y una ampliación de la representación hasta llegar a las reformas de los Reyes Católicos, los cuales sientan las bases para erigir una Monarquía fuerte, acompañada de un remozado Consejo Real, a la que corresponden unas Cortes -y un reino, por ende- débiles ${ }^{96}$. Lo que ha sucedido con las Cortes, ha sucedido asimismo con otras Leyes Fundamentales, cuya nómina enumera el jurista de Elda, y pone como ejemplo de todo esto a Alfonso X: ningún tiempo fue más propicio para alcanzar la felicidad pública y, sin embargo, ningún tiempo fue más desgraciado que esos años centrales del siglo XIII. Las irrefrenables ansias reformistas del monarca acabaron por arruinar al reino en todos los campos imaginables, lo que prueba que nada había fijo, estable, sólido, y que la mejor formación tampoco aseguraba el éxito político ${ }^{97}$. El fortalecimiento posterior del poder regio fue la clave para ello, es decir, los reyes -y no el reino- fueron la llave del esplendor, lo que contradice de principio a fin el discurso de Martínez Marina. A España le ha ido mejor (y, en consecuencia, le irá mejor en el futuro) en todos los sentidos cuando menos se ha respetado esa pretendida Constitución tradicional. Los Austrias, primero, y los Borbones, después, lo prueban con claridad meridiana. Por eso, el siglo XVI, con Carlos I y Felipe II, fue el de la grandeza más excelsa, no derivada de la excelencia de la Constitución política, y lo mismo sucedió en el siglo XVIII con los Borbones que despiertan a una Monarquía aletargada (hasta Carlos IV, quien destruye lo bueno que sus padres habían edificado, lo que desembocará de inmediato en una gran crisis que no admite parangón histórico, de la que puede salir lo mejor, globalmente hablando, o que puede hundir a la Monarquía para siempre: crisis que no admite término medio, o funesta, o saludable). El respeto al pasado, a la tradición, al Derecho histórico, no es garantía de nada, sino, al contrario, una rémora de la que hay que prescindir ${ }^{98}$. No hay Constitución, ni Leyes

juntas convocadas pocas veces por los reyes y compuestas solamente de obispos, abades y los oficiales de su corte que gustaban convidar".

${ }^{95}$ Cfr. J. Sempere y Guarinos, Observaciones, ed. cit. II, pp. 72 ss.

${ }^{96}$ Cfr. J. Sempere y Guarinos, Observaciones, ed. cit. III y IV, pp. 77 ss. El papel central del Consejo Real está desarrollado en su Historia de las Cortes, ed. cit. Cap. XXIV, pp. 125 ss., lo que lleva a pensar en aquél como el principal baluarte del gobierno monárquico y auténtico contrapeso, fáctico y jurídico, de las Cortes.

${ }^{97}$ Cfr. J. Sempere y Guarinos, Observaciones, ed. cit. V, p. 100: "Los efectos de su desalumbrada política fueron perder aquel gran pleito con sus inmensas costas, gravar a la nación con las incalculables que le ocasionó después la jurisprudencia italiana, disgustar a sus vasallos y dar lugar a que, rebelándose su hijo, lo dejaran casi solo la mayor parte de sus pueblos y reducido a tanta pobreza, que tuvo que empeñar una corona en Fez por 60 doblas y confederarse con aquel rey para sujetar a D. Sancho, lo que no pudo conseguir".

${ }^{98}$ Cfr. J. Sempere y Guarinos, Observaciones, ed. cit. V, pp. 101 ss. Cfr. asimismo, su Historia de las Cortes, ed. cit. Prefacio, p, 7: "Finalmente se verá que si hubo un tiempo del que se pudo decir que España fue feliz, rica y poderosa, fue sólo durante el siglo XVI, es decir cuando la autoridad real se libró 
Fundamentales inmutables, ni pasado que reivindicar. La lectura de Martínez Marina se invierte: fueron peores aquellos tiempos en que floreció la Constitución medieval, mientras que su ocultación, desconocimiento o simple violación han dado paso a mejoras sustanciales, a los mejores rendimientos y a óptimos resultados ${ }^{99}$. ¿Qué hacer en ese año 1810? Se imponía una metamorfosis de corte constitucional que llevase a abandonar el pasado y a crear una nueva Constitución, cuyo sustento sería ella misma y cuyo límite vendría determinado por la voluntad del pueblo. Creyó así Sempere y Guarinos percibir en Bayona ese cambio, pero la falta de apoyo popular frustra el empeño de José $\mathrm{I}^{100}$. Hallamos, pues, una mutación de tendencia que no se debe al capricho, ni a la enemistad, sino a una profunda reflexión sobre la realidad de su época, que hace tomar como referencia la Historia, pero de un modo realista, con cierto racionalismo jurídico, y un flamante rechazo de mitologías y leyendas, de idealizaciones y fábulas. La legitimidad del nuevo tiempo debía proceder de las exigencias, demandas y necesidades del presente. La Constitución tenía que clausurar el tiempo antiguo, y, como resultas de lo anterior, erigirse a partir de la Nación y a partir de sí misma como texto racional y normativo, sin otros complementos o añadidos. Sempere y Guarinos fuerza así al liberalismo, o, al menos, a ciertos sectores de éste, a abandonar los terrenos de la Historia, coto donde absolutistas y reaccionarios campaban a sus anchas, para ingresar en el campo de la razón ${ }^{101}$.

Abundando en todo lo anterior, en su Memoria primera sobre la Constitución gótico-española, aparecida en Paris en el año 1820, parte única de unas Memorias para

de las trabas de la constitución gótica y feudal; cuando se reformaron muchos usos y privilegios, bien de los nobles, bien del estado llano; cuando se dio una nueva forma a la milicia y a la magistratura y, en definitiva, cuando las famosas Cortes, que en sus tiempos de poder y de influencia estaban constituidas por ricohombres, obispos y procuradores de todas las ciudades, pasaron a reunir únicamente a los representantes de veinte ciudades y conservaron apenas una sombra de su antigua representación". A mayores, cfr. Historia de las Cortes, ed. cit. Caps. XVII-XVIII, pp. 93 ss.; y Caps. XXX-XXXI, pp. 153 ss. Ni siquiera se salvan las Cortes aragonesas, en op. cit., Caps. XX-XXI, pp. 105 ss., donde existía asimismo un gobierno militar o feudal, contra el parecer de la mayor parte de la historiografía, aunque su Constitución era algo más libre que la castellana.

${ }^{99}$ Tema que retomará, como se sabe, en 1826, al publicar las Considerations sur les causes et la décadence de la monarchie espagnole. Paris, 1826. 2 tomos. Interesa ahora el Tomo I. Caps. XX-XXI, pp. 209 ss. (Hay edición en español: Consideraciones sobre las causas de la grandeza y de la decadencia de la monarquía española. Traducción, estudio preliminar y notas de Juan Rico Giménez. Alicante, 1998).

${ }^{100}$ Cfr. J. Sempere y Guarinos, Observaciones, ed. cit. V, pp. 105-106: "La sabia constitución que le ha de servir de basa fundamental, asegurando ante todas las cosas el ejercicio más puro de nuestra sagrada religión para la felicidad eterna, establece al mismo tiempo los verdaderos principios de la temporal, que consisten en la seguridad de la vida y de los bienes, y en la justa libertad civil y política para gozarlos y comunicarse francamente todos los ciudadanos sus ideas y sus sentimientos (...) Las opiniones, las costumbres y aun hasta las leyes más fundamentales varían con los tiempos, como lo enseña la historia de todas las naciones y acabo de demostrarlo en la nuestra, no con sofistería ni con el estilo pomposo y declamatorio de los escritos revolucionarios, sino con los hechos más ciertos y notables y algunas sencillas observaciones sobre los resultados".

${ }^{101}$ Cfr. J. Sempere y Guarinos, Historia de las Cortes, ed. cit. Cap. XXXIX, pp. 205 ss. 
la Historia de las Constituciones españolas ${ }^{102}$, en estrecha relación con su Historia de las Cortes, aparecida en francés en $1815^{103}$, y frente a las idílicas y casi paradisíacas visiones de muchos de su coetáneos, presenta un escenario histórico opuesto, dominado por la anarquía y el despotismo, por poderes regios arbitrarios, tanto en tiempos godos como en los medievales, por la negación del valor auténticamente popular a las Cortes, por la ausencia de representación general y por el maltrato o desprecio continuo al estamento ciudadano en tales asambleas. La antigua Constitución gótica no existió con los perfiles que se le quisieron atribuir, a modo de anticipo de la Modernidad, sino que fue caldo de cultivo del peor de los despotismos imaginables y además varió a lo largo de su secular existencia, por lo que no se pueda hablar de ella en singular. Fue cambiando siempre lo que impide hablar de una inmutabilidad y de una estabilidad en la misma como atributos prototípicos de toda Constitución. No lo es la referida germánica. Por eso, para romper con la Historia y con el pasado, que han sido los argumentos empleados para dotar de legitimidad a la Constitución tradicional, debe investigarse ese pasado con el fin de conocerlo y de contemplar la carencia de continuidades y de paralelismos, con lo que se concluye por rechazar la historicidad como fuente de poder alguno. Su lucha histórica es, en suma, una lucha jurídica que tiene como objetivo buscar otra fuente, ahora ya moderna, para la legitimación constitucional, que él halla precisamente en la razón, dando un salto cualitativo que Martínez Marina no había sido capaz siquiera de vislumbrar. Si este último seguía moviéndose en terrenos escolásticos, Sempere y Guarinos se enroca en el campo de un iusnaturalismo moderadamente racionalista y claramente decisionista, como ya se ha apuntado, que atisba ciertas posibilidades de ruptura del modelo político-jurídico conocido. Con este fin, examina, pues, la Historia de los godos, su primitiva Constitución, las relaciones con el Imperio, su establecimiento en España, los cambios de sus estructuras de poder y de sus costumbres y leyes, etc., para mostrar una análisis y un diagnóstico totalmente opuesto al dominante. El resultado de todo esto es la caída del mito gótico por su propio peso y, con ello, de la Constitución histórica, mediante una relectura de los materiales de todo tipo que sirvieron igualmente a otros autores para propósitos políticos y conclusiones doctrinales contrarios ${ }^{104}$. Sus argumentos muestran una rotundidad muy marcada que apuntala todo lo anterior: que las luchas intestinas de los nobles godos apoyan la conclusión de que el carácter electivo de la realeza era más

${ }^{102}$ Cfr. J. Sempere y Guarinos, Memoria primera, ed. cit., pp. 107-201; e Historia de las Cortes, ed. cit. Cap. III, pp. 17-23. Sobre el particular, vid. R. Herrera Guillén, "Monarquía visigoda en Sempere y Guarinos", en Res Publica. Revista de Filosofia Política. Año 10, $\mathrm{n}^{\circ} 17$ (2007) (= Las ideas políticas medievales), pp. 177-186.

${ }^{103}$ Cfr. J. Sempere y Guarinos, Historia de las Cortes, ed. cit. supra, que actúa como contrapunto a la Teoría de Martínez Marina. La obra aparece como Histoire des Cortès d'Espagne. Burdeos, 1815. En 1834, a modo de extracto de ese volumen antecedente, aparece un Resumen de la historia de las antiguas Cortes de España, escrita en francés por D. Juan Semper, español, fiscal que fue de la Chancillería de Granada. Traducida al castellano por D. Toribio Picatoste. Madrid, 1834.

${ }^{104}$ Cfr. J. Sempere y Guarinos, Memoria primera, ed. cit. XVII-XX, pp. 164 ss. 
nominal que efectivo; que el rey no se apoyaba en la Nación, sino en facciones variadas y oscilantes; que aquellos gobernaron para sí mismos y para sus fieles, sin tener en cuenta el bien común; que depredaron y devastaron los reinos; que los Concilios ni representaban a la Nación, ni tenían más poderes y atribuciones que el de aclamación de todo aquello cuanto rey, nobleza y clero hubiesen decidido; que fueron irregulares y discontinuos, de composición alterable y alterada; que la Iglesia hizo más llevadero el sistema político, pero sin reformarlo en profundidad y sin cuestionarlo abiertamente; y que ni siquiera el Fuero Juzgo merece una valoración positiva, aunque comparado con los demás códigos de los bárbaros, se encontrarán en él más considerados y protegidos los derechos del hombre y algunas basas fundamentales de la sociedad ${ }^{105}$. No eran ejemplos a seguir en el presente porque de allí no se desprendían ni virtudes, ni buenas costumbres, ni honor, ni patriotismo. No es una Constitución la gótica que merezca ser rehabilitada o que guarde consonancia con lo que España demandaba a comienzos del siglo XIX. La ferocidad goda no fue suavizada más que por la teocracia católica, pero sin mayores efectos. Fue una Nación mal gobernada y ya se sabe que una nación bien gobernada puede multiplicar al infinito sus riquezas y sus fuerzas; $y$ al contrario, sin buen gobierno se empobrecen, decaen y se anonadan las más fuertes y opulentas. Eso sucedió con los visigodos: su Código y su Religión no eran más que pretextos para servir a intereses privados y a los vicios de sus gobernantes, siendo escudos de la tiranía, lo que enfrió su patriotismo y justificó su ruina final provocada por la indiferencia a ser sometidos ya por naturales, ya por extranjeros. La indolencia es el resultado del mal gobierno que impide que nazcan buenos ciudadanos, que impide el amor a la patria, y que impide la búsqueda del interés general. La falta de sujetos ejemplares y virtuosos, bien reyes, ministros o gobernantes, bien eclesiásticos, bien súbditos, así como la carencia de sentimientos y de objetivos colectivos y generales, sellaron el destino de aquel cuerpo político y lo llevaron a la desaparición ${ }^{106}$. De modo tangencial, se acaba por llegar a Alfonso X El Sabio a propósito de ese Fuero Juzgo minusvalorado: estuvo vigente hasta tiempos del citado monarca, quien, sin derogarlo expresamente, introdujo doctrinas y máximas incompatibles con la legislación goda. Extranjerizó el reino, fomentó el estudio de la jurisprudencia boloñesa y gestó las Partidas, repletas de leyes y máximas ultramontanas, que fueron preferidas por los juristas, formados en ellas dentro de las universidades, frente a las antiguas y más nacionales, frente al Derecho propio. Aun no siendo revocadas y aun a pesar de ser las Partidas postergadas en el esquema jerárquico del Ordenamiento de Alcalá y de los códigos posteriores, acabaron por convertirse en el cuerpo principal del Derecho de la Corona porque los prácticos y demás operadores jurídicos reafirmaron tal suerte: Siendo éstas más conformes a las opiniones de los jueces y consejeros, fueron prevaleciendo por todas partes, sin que hayan bastado los esfuerzos más vigorosos del gobierno español

${ }^{105}$ Cfr. J. Sempere y Guarinos, Memoria primera, ed. cit. XXI, pp. 182-190.

${ }^{106}$ Cfr. J. Sempere y Guarinos, Memoria primera, ed. cit. XXII, pp. 190-192. 
para contener sus progresos y abusos ${ }^{107}$. Algo se había roto respecto a la valoración encomiástica de los tiempos inmediatamente precedentes. Ya no se encuentra la unanimidad previa. Sempere y Guarinos es el abanderado de una revisión crítica que arrastra la obra de Alfonso X hacia unos derroteros sumamente negativos. Con toda probabilidad, porque quien habla en tal sentido no es el historiador, como sí lo era Martínez Marina, sino el jurista que conoce el estado real de la Justicia y del Derecho en España, que sabe cómo funcionan los Consejos, Audiencias y tribunales, que sabe cuáles son los defectos, errores y vicios del sistema, y que sabe a quién se pueden imputar todos ellos. Lo que antes tenía de positiva la obra alfonsina, se transmuta en todo lo contrario.

Su Historia del Derecho, de los años 1822 y $1823^{108}$, explicita este cambio profundo que no va a tener continuadores, ni excesivos seguidores, posiblemente debido a la radicalidad valorativa que implicaban sus postulados. Se condensan aquí sus argumentos anti-historicistas y la contención de antaño deja paso a una rabiosa crítica del sistema jurídico heredado de Alfonso X. Al tratar la obra del monarca, inicia Sempere y Guarinos con una descripción aséptica de cada una de las normas conocidas, una descripción puramente histórica y legal, formal, externa, estética, sin entrar en consideraciones políticas de género alguno. En ningún momento -y aquí otra diferencia respecto a la erudición coetánea-, son calificadas tales normas como Leyes Fundamentales o como parte de una pretendida Constitución histórica. Es silencio elocuente que había anticipado, como se ha visto, Canga Argüelles, el cual se negaba a otorgar este calificativo de una manera gratuita. Para el contexto, Sempere y Guarinos bebe de opiniones anteriores, pero a diferencia de Martínez Marina, da un sesgo a su exposición más erudita y europeizante a la hora de ligar Castilla y León con el universo del Derecho Común, esto, es, elabora una exposición menos enfocada en la Península y más enraizada en el movimiento general que se dio a lo largo y ancho del continente en los siglos centrales del Medievo ${ }^{109}$. Para afrontar la obra alfonsina, los autores invocados son los ya conocidos, integrantes de una tradición de siglos: Zurita, Mariana, Nicolás Antonio y Burriel. Los objetivos del rey son también notorios y eran admitidos por todos: reformar el Derecho y caminar hacia su uniformización con la modificación de los tribunales para hacer efectivo todo lo anterior. E1 Fuero Real sería el primer ejemplo de esto, no obstante la resistencia nobiliaria ${ }^{110}$, al

\footnotetext{
${ }^{107}$ Cfr. J. Sempere y Guarinos, Memoria primera, ed. cit. XXI, p. 189.

${ }^{108}$ Cfr. J. Sempere y Guarinos, Historia del Derecho Español. Madrid, 1822. Tomo I; y Madrid, 1823. Tomo II. Anteriormente, había esbozado el contenido de este tratado suyo, al menos en la parte que ahora interesa, en unas Memorias históricas. Apuntamientos para la Historia de la Jurisprudencia española, aparecidas en su Biblioteca Española Económico-Política. Madrid, 1804. Tomo II, §§. XVIIXXXV, pp. 43-125; y también en su Historia de las Cortes, ed. cit. Prefacio, p. 7; y, sobre todo, Cap. XI, pp. 51-55. En ambos textos, insinúa el carácter meramente doctrinal de las Partidas.

${ }^{109}$ Cfr. J. Sempere y Guarinos, Historia del Derecho, ed. cit. Tomo II. Libro III, cap. I, pp. 1-8.

${ }^{110}$ Cfr. J. Sempere y Guarinos, Historia del Derecho, ed. cit. Tomo II. Libro III, cap. II, pp. 8-18.
} 
que siguen el Setenario, atribuido a su padre, San Fernando, pero culminado por Alfonso, y el Espéculo, incompleto ${ }^{111}$.

Al llegar a las Partidas, redactadas como consecuencia de las pretensiones imperiales alfonsinas, el jurista estalla y la moderación anterior da paso a un ciclón de reproches que se realizan a la vista de las consecuencias negativas derivadas de aquellas imprudentes e irreflexivas decisiones del Rey Sabio, consecuencias que el autor ha vivido a lo largo de su carrera profesional en primera persona. No es siquiera una obra literaria de calidad (etimologías superfluas, definiciones y descripciones inexactas, oscuras, citas innecesarias, contradicciones por la confusa mezcla de legislaciones eclesiástica, de los fueros, profana, feudal, real, etc. $)^{112}$. Formalmente son muy defectuosas, pero el contenido no le va a la zaga en este enjuiciamiento severo. La dura crítica no va dirigida a la tradición de la que se apartó Alfonso, sino a la obra en sí y a lo que ésta supuso, a su influjo inmediato y mediato. Lejos de merecer los exagerados elogios de algunos coetáneos, han sido las Partidas uno de los mayores males que ha sufrido la monarquía española por sus efectos perniciosos. Afectó a todos y a nadie dejó contento por lo que todos reaccionaron en su contra. Intentó transformar de golpe y sin oportunidad, imprudentemente, toda la legislación antigua, despojar a los estamentos y a los pueblos de sus fueros y preeminencias, y hasta al mismo monarca de sus derechos esenciales e inseparables de la soberanía. Originó la conspiración de la nobleza, aumentó la confusión normativa por su mezcla de componentes, debilitó el poder del rey en provecho del papa, aumentando la discordia entre Imperio y Sacerdocio, entre otros logros nefastos ${ }^{113}$. Sus novedades son asimismo perniciosas, como acontece con los mayorazgos, bien conocidos por Sempere y Guarinos, o con la enajenación perpetua de bienes del Estado ${ }^{114}$. Es obra monstruosa, confuso amontonamiento de erudición, confuso hacinamiento de presupuestos falsos, de citas impertinentes y de razones frivolas, suma de leyes extranjeras y contradictorias, que servían para inventar lo que era, a sus ojos, el Derecho natural y el Derecho divino ${ }^{115}$. Por todos estos defectos, duda muy fundadamente de que las Partidas tuviesen carácter normativo, sino más bien doctrinal y educativo: fueron un texto dirigido a enseñar e ilustrar, no orientado a mandar o a imponer, un texto didáctico que trataba de preparar al pueblo para ulteriores reformas ya plenamente jurídicas, esto es, decididamente coactivas ${ }^{116}$. Tomando como referencia tiempos visigodos y medievales, realiza un análisis de las tres primeras Partidas, siendo especialmente duro con la primera de ellas. Un claro tono anticlerical preside las líneas que Sempere y Guarinos le dedica. La emergencia de una gran autoridad eclesiástica, combatida por la auto-

${ }^{111}$ Cfr. J. Sempere y Guarinos, Historia del Derecho, ed. cit. Tomo II. Libro III, cap. III, pp. 18-24.

${ }^{112}$ Cfr. J. Sempere y Guarinos, Historia del Derecho, ed. cit. Tomo II. Libro III, cap. III, p. 27.

${ }^{113}$ Cfr. J. Sempere y Guarinos, Historia del Derecho, ed. cit. Tomo II. Libro III, cap. III, p. 28.

${ }^{114}$ Cfr. J. Sempere y Guarinos, Historia del Derecho, ed. cit. Tomo II. Libro III, cap. IV, pp. 33 ss.

${ }^{115}$ Cfr. J. Sempere y Guarinos, Historia del Derecho, ed. cit. Tomo II. Libro III, cap. V, p. 44.

${ }^{116}$ Cfr. J. Sempere y Guarinos, Historia del Derecho, ed. cit. Tomo II. Libro III, cap. V, p. 44. 
ridad civil, marcará este periplo futuro en el campo de las relaciones entre los dos poderes. Esas tres primeras partes bastan y sobran para conocer el espíritu de la legislación alfonsina (no era precisa la minuciosidad de Martínez Marina) y para poner de relieve su gran discrepancia respecto al Derecho visigodo, al feudal o al medieval de los fueros ${ }^{117}$.

No obstante todo esto, es cuerpo normativo que acaba por triunfar y complicar mucho más la situación jurídica de los reinos, haciéndola de todo punto irresoluble e insostenible. Por tal razón, critica Sempere y Guarinos el Ordenamiento de Alcalá y las Leyes de Toro, que propiciaron tal encumbramiento de la obra alfonsina y del Derecho romano-canónico que venía de su mano, con lo que pospusieron la aplicación del Derecho nacional y provocaron su consecuente ruina ${ }^{118}$. Todo ello se acompaña de una erudita reconstrucción de las más relevantes instituciones de la Corona, desde los concejos, hasta las Audiencias y el siempre presente Consejo Real. El panorama no cambia en los momentos intermedios y el Derecho castellano-leonés, ya nombrado español, es una gran confusión, un gran compendio amorfo de textos procedentes de varias épocas, territorios, reyes e instituciones anexas. Las normas se suceden, se acumulan, se superponen, pero el orden no llega nunca. Ése es el gran defecto que no acaba de solucionarse, ni parece estar en trance de serlo. La admiración por los Borbones que se deduce de sus líneas, excepto por Carlos IV, no oculta una necesidad sentida de cambios más allá de las reformas debidas a aquella innovadora familia real. La jurisprudencia había sido la ciencia que menos progresos había experimentado a lo largo del siglo XVIII ${ }^{119}$. El Derecho conocido y aplicado, en clara falta de armonía con los usos prácticos y sin poder satisfacer las necesidades de la época, debía ser reemplazado por un código general completo, acomodado al desarrollo de las ideas y basado en la fuerza de las costumbres dominantes, ya antiguas, ya templadas o revisadas por los tiempos recientes. De nuevo, aflora su racionalismo moderado, pero racionalismo a fin de cuentas ${ }^{120}$. Evidentemente, no lo hizo así, ni de lejos, la Novísima Recopilación. España seguía siendo, jurídicamente hablando, un intrincado laberinto ${ }^{121}$. La labor gaditana es estudiada de un modo detallado para con-

${ }^{117}$ Cfr. J. Sempere y Guarinos, Historia del Derecho, ed. cit. Tomo II. Libro III, caps. VI-IX, pp. 48 ss. ${ }_{118}$ Cfr. J. Sempere y Guarinos, Historia del Derecho, ed. cit. Tomo II. Libro III, cap. XVIII, pp. 136147; y Libro IV, cap. II, pp. 242-249.También, cfr. sus Consideraciones, ed. cit. Primera Parte. Cap. X, pp. 53-55; y, sobre todo, Cap. XIII, pp. 61-62. Un ejemplo práctico de esa crítica se puede contemplar en su Historia de los vínculos y mayorazgos. Estudio preliminar de Juan Rico Giménez. Alicante, 1990. Caps. XX-XXI, pp. 167 ss.; y Cap. XXIII, pp. 185 ss.

${ }^{119}$ Cfr. J. Sempere y Guarinos, Historia del Derecho, ed. cit. Tomo II. Libro IV, caps. XIII-XXIV, pp. 333 ss.; y Consideraciones, ed. cit. Tercera Parte. Caps. I-IV, pp. 189 ss.

${ }^{120}$ Lo apunta en su Historia del Derecho Español. $2^{\mathrm{a}}$ edición. Madrid, 1844. Libro IV, cap. XXV. Apéndice, pp. 521-522, con loa a las Partidas, "el trabajo más perfecto de nuestra legislación".

${ }^{121}$ Cfr. J. Sempere y Guarinos, Historia del Derecho, ed. cit. Tomo II. Libro IV, cap. XXIV, pp. 388389. La expresión es del Colegio de Abogados de Madrid, formulado en el mes de enero de 1819 a propósito de la Novísima. 
cluir, de conformidad con lo que eran sus deseos antes que las medidas efectivas adoptadas por las Generales y Extraordinarias (de nuevo apartándose de sus coetáneos), que esas Cortes, al trabajar la reforma, y con especialidad la relativa al derecho político, no tuvieron miramiento alguno ni á los antiguos usos de España o sus diversas provincias, ni á las opiniones ya identificadas con el pueblo respecto a la Constitución y gobierno de la monarquía, por más que así lo proclamasen: lejos de esto consignaron doctrinas extraordinarias y nuevas, viniendo a oponer lo que se llamaba en Francia imperio de la razón y adelantos de la filosofía, á la fuerza incontrastable de la costumbre ${ }^{122}$. Aire nuevo insufla en ese panorama historiográfico y jurídico nuestro autor, con una acentuada proximidad al mundo del Derecho que le lleva a explicar lo que Martínez Marina sólo contemplaba desde la distancia, es decir, que la obra de Alfonso X, lejos de ser motivo de orgullo, es causa de lamentaciones, de desgracias, de fárrago y de lentitud para todo el orden jurídico conocido. Revisión crítica, pues, de la obra de Alfonso X, demoledora en todos los extremos, tanto políticos (algo ya usual) como jurídicos (acaso la gran novedad en el planteamiento de Sempere y Guarinos), pero revisión minoritaria y sin alcance a los efectos académicos oportunos, sin repercusiones más allá de algunos reducidos círculos. La historiografía seguía la línea trazada magistralmente por Martínez Marina y será éste quien domine el panorama intelectual en los años que ahora nos van a ocupar.

3. El proceso constitucional -que no constituyente, por lo que se dirá a renglón seguido-que se inicia en el mes de marzo de 1808 hace que pase a un primer plano la idea de la Constitución histórica y de las Leyes Fundamentales que la componen, contrariamente a lo que debería haber sucedido en el caso de desarrollarse una dinámica dirigida a la forja de una Constitución radicalmente nueva, como aconteció en las experiencias revolucionarias del siglo XVIII y que España no va a compartir. Nunca se habían ido del todo aquellos tópicos constitucionales referidos. Es el pensamiento ilustrado el que domina la situación, pues ilustrados son los hombres públicos del momento, y los fermentos ideológicos precedentes no hacen más que germinar cuando, ante las crisis de la Monarquía, lo que se respondió fue más y mejor Constitución tradicional, más y mejor pasado para encauzar y recomponer ese presente enfermo. Porque el objetivo que se plantea desde la marcha de los reyes a Bayona y su posterior abdicación es una recomposición de la Monarquía, una rehabilitación de la misma a partir de la Nación, nunca la eliminación o erradicación de aquélla, sino, al contrario, su conservación y perfeccionamiento, para lo cual debía tomarse como patrón de medida el conjunto de Leyes Fundamentales que determinaban su

${ }^{122}$ Cfr. J. Sempere y Guarinos, Historia del Derecho Español. $2^{\text {a }}$ edición. Libro IV, cap. XXVI, pp. 527 ss. Lo cual contrasta de modo abierto con las ideas expresadas, anteriormente, en su Historia de las Cortes, ed. cit. Cap. XXXIX, pp. 205-208; y, posteriormente, en sus Consideraciones, ed. cit. Tercera Parte. Cap. V, pp. 230-236. 
sustento y su funcionamiento previo, sin olvidar posibles mejoras, enmiendas y correcciones que las necesidades de los tiempos hacían preciso introducir como se había puesto de manifiesto. No hay una clara voluntad constituyente, sino reconstituyente, lo cual viene condicionado por una triple imposibilidad concatenada que se produce en tales tiempos convulsos e inciertos: la imposibilidad de una Nación plenamente liberal, la imposibilidad de una soberanía nacional y la imposibilidad de una verdadera representación nacional. Sin tales instrumentos, era muy difícil, por no decir irrealizable, que se articulase un poder constituyente, un poder que pudiera actuar con la plena libertad que había demostrado en el caso estadounidense o en el caso francés, es decir, con la contundencia suficiente para determinar libremente y sin vínculos de ninguna clase qué era la Constitución y cuáles sus contenidos, para erradicar la Historia como dictaminadora de la realidad política y para convertir en despojo todo ese antiguo legado de Leyes Fundamentales, afirmando la voluntad nacional como única y exclusiva fuente del poder. Crear un antiguo régimen exigía erigir uno nuevo, aunque fuese empleando muchos de los instrumentos y mecanismos del primero. La dicotomía Historia-Política se volvía a plantear. Si se hacía Historia, la Nación no podía enfrentarse a la misma, sino aceptarla y asumirla: era algo imbatible y determinante. Si, por el contrario, era la Política como decisión la que triunfaba, la Historia pasaría a un rincón secundario y no tendría ninguna virtualidad ordenadora. Fue lo primero lo que predominó con claridad y casi con unanimidad. El preámbulo de la Constitución de Cádiz, culminación de esta época, será muy expresivo en este sentido: las Cortes han procedido a examinar y deliberar sobre las antiguas Leyes Fundamentales y las han entendido subsistentes en su inmensa mayoría, si bien acompañadas de las oportunas providencias y precauciones, que aseguren de un modo estable y permanente su entero cumplimiento para realizar su objetivo principal que era promover la gloria, la prosperidad y el bien de toda la Nación. No han hecho Constitución novedosa, sino que han procedido a reordenar la vieja subsistente y a asegurarla con los mejores medios posibles ${ }^{123}$. El punto de partida eran, pues, las Leyes Fundamentales, que pasarían a ser revisadas y aseguradas en atención a lo que la misma Monarquía (y la Nación, que iba de su mano) reivindicaban en esos instantes. Lo que había funcionado durante siglos, podía y tenía que seguir funcionando con mínimos ajustes y revisiones. El recurso a este tópico es constante, como ya se ha podido ver, a lo largo

${ }^{123}$ Es el argumento principal de mi trabajo "Repensar la Constitución de 1812: Cádiz o el imposible constituyente", en Historia et Ius. Rivista di Storia Giuridica dell'Età Medievale e Moderna, $\mathrm{n}^{\mathrm{o}} 3$ (giugno, 2013). Paper $n^{\circ} 6$ (http://www.historiaetius.eu/uploads/5/9/4/8/5948821/martinez.pdf), al que remito in toto con la bibliografía allí indicada. Desde otra perspectiva, anticipa y complementa esa visión, aunque sin compartir radicalidad inconstituyente como en mi caso, C. Garriga, "Cabeza moderna, cuerpo gótico. La Constitución de Cádiz y el orden jurídico”, en AHDE, no 81 (2011), pp. 99-162. Sumada a las indicaciones recogidas supra en la Parte Primera de este trabajo, nota $\mathrm{n}^{\circ} 47$, y para una revisión de la abundante producción bibliográfica surgida al amparo del bicentenario gaditano, vid. B. Clavero, "Cádiz, 1812: antropología e historiografía del individuo como sujeto de Constitución", en Quaderni Fiorentini per la Storia del Pensiero Giuridico Moderno, no 42 (2013), pp. 201-279. 
y ancho de la obra de la mejor intelectualidad del momento, la que viene de la centuria pasada. No cesa esta tendencia en los primeros compases del siglo XIX. Allí mismo, en ese lugar tan transitado por todo el mundo, tendrán su ubicación las Partidas de Alfonso X y su restante obra legislativa, encuadradas ahora en una dimensión más práctica que teórica, es decir, como Derecho de los reinos que, como tal, ha de ser valorado en su justa medida, ha de ser reivindicado como parte sustancial de todo ese universo político-jurídico y, eventualmente, puede ser objeto de cambios, modificaciones o mejoras. Se reconoce, se aplica, se muta, porque se tiene conciencia tanto de su vigencia incuestionada como de su importancia capital. Lo invocan tanto las viejas instituciones desfallecientes y criticadas (caso del Consejo de Castilla) como los prohombres del momento (Jovellanos o Calvo de Rozas, por citar dos ejemplos señeros), en un intento de hacer ver que las excepcionales circunstancias coetáneas tenían reflejo y posible respuesta o encaje en los viejos cuerpos jurídicos de la Monarquía, donde estaba todo contenido a modo de una biblioteca universal e infinita. De esa manera, se rebajaba el tono de excepcionalidad y de gravedad del instante vivido, buscando cierta normalidad o tranquilidad que era urgente implementar, y se reconducía la problemática hacia un orden ya conocido y establecido donde era fácil rastrear y hallar sustento, ejemplos, indicaciones, pautas de conducta. Y, sobre todo, se daba respuesta a los acuciantes problemas de ese instante histórico irrepetible, sin necesidad de crear o de inventar nada novedoso, eludiendo los peligrosos caminos de la novedad. Es un hecho incontestable, pues, que la obra alfonsina, no obstante las críticas ya vistas, era una pieza esencial de nuestra Constitución, acaso una de las más determinantes. Nadie, salvo Canga Argüelles, al mismo tiempo que las Cortes comenzaban su periplo, y Sempere y Guarinos en época posterior, pero con ideas gestadas en aquel entonces, lo ponía en duda. Por eso, no sorprende su presencia continuada en el debate constitucional que se inicia en 1808 y culmina en 1812, pero tampoco puede dejar de sorprender su presencia mediatizada a partir de la visión proporcionada por los ilustrados acerca del rey y de su obra legislativa.

Los hechos son muy conocidos lo que evita que nos tengamos que detener en ellos $^{124}$. Tras la formación de la Junta Central, en el mes de septiembre de 1808, como centro político que aglutinaba la dirección y coordinación de las varias Juntas Provinciales para cuestiones de guerra y de economía, cobra fuerza la propuesta de convocar Cortes con las cuales hacer frente a las necesidades constitucionales que España demandaba en ese preciso instante. De nuevo, había que volver a la tradición, aunque

\footnotetext{
${ }^{124}$ Vid. J. Fontana Lázaro, La crisis del Antiguo Régimen, 1808-1833. Barcelona, 1979; F. Suárez, La crisis política del Antiguo Régimen en España (1800-1840). $3^{a}$ edición. Madrid, 1988; J. P. Fusi y J. Palafox, España: 1808-1996. El desafio de la modernidad. Madrid, 1997; M. Artola, La España de Fernando VII. Introducción de Carlos Seco Serrano. $3^{\mathrm{a}}$ edición. Madrid, 2008 y La revolución española (1808-1814). Madrid, 2010; R. Carr, España 1808-2008. Edición revisada y actualizada por Juan Pablo Fusi. 2a edición. Barcelona, 2009; y F. De Angelis, La rivoluzione spagnola degli anni 1808-1810. Alla ricerca di un modello politico-costituzionale tra antico regime e rinnovamento. Roma, 2010.
} 
las soluciones presentadas y debatidas no solamente contemplaban este extremo recurso parlamentario, sino que invocaban otras posibilidades igualmente históricas (Juntas, Consejos, Regencias, etc.). En todo caso y tras arduos debates, la propuesta que triunfa es la de reunir Cortes con el fin de abordar una serie de urgentes e imperativas reformas dirigidas a hacer más fuerte y más duradera esa anciana Constitución por medio de la Nación. Jovellanos será el que lleve la voz cantante. Su idea de las Cortes es la que acaba por fructificar en el famoso Decreto de 22 de mayo de 1809, resultado de muchas propuestas, minutas y documentos previos ${ }^{125}$, aunque la norma final aprobada era insuficiente por parca, lacónica y simple. Era aquélla un texto que dejaba pendientes muchas cosas acerca de una tal asamblea, pero que ideaba una Comisión (llamada de Cortes), la cual, acompañada de varias Juntas auxiliares de ella dependientes y creadas en momentos sucesivos, sería la encargada de ir resolviendo las dudas surgidas en el desarrollo de los acontecimientos respecto a qué tipo de Cortes (unicamerales o bicamerales), su composición, sus competencias o el cómo iniciarlas, gestionarlas y desarrollarlas. La Junta Central no creaba, en puridad, las Cortes, sino que las reinstauraba: los desastres que vivía la Nación, se lee en el preámbulo del mencionado Decreto de 1809, eran el resultado de haber dejado caer en el olvido las saludables instituciones que en tiempos más felices hicieron la prosperidad y la fuerza del Estado, provocando una felicidad pública incomparable, ahora mismo obstruida y estorbada por doquier, cuando no fracturada, quebrada, descompuesta. Usurpaciones y abandono indolente fueron reduciendo las Cortes a la nada. Había que restablecerlas, no fundarlas, porque ya existían. Se trataba de meditar las reformas que debían efectuarse en la administración, asegurándolas en y con las Leyes Fundamentales de la Monarquía, para consolidar tanto a unas como a otras. Los sabios y la propia Nación debían hacerse sentir y debían ser escuchados. Pero, en realidad la convocatoria, nada decía acerca del modelo de Cortes que tenían que ser actuadas. Confiaba el desarrollo del proceso abierto a la citada Comisión de Cortes, de cinco miembros, e impulsaba una Consulta al País, preferentemente sobre cuestiones bélicas, económicas y militares, pero dando cabida asimismo a otras político-jurídicas, como las relativas a esa latente, oculta e ignorada Constitución, puesto que se preguntaba por aquellos medios precisos para asegurar la observancia de las Leyes Fun-

${ }^{125} \mathrm{El}$ texto de este Decreto sobre restablecimiento y convocatoria de Cortes, expedido por la Junta Suprema gubernativa del Reino, de 22 de mayo de 1809, en M. Fernández Martín, Derecho parlamentario español. Madrid, 1992. Tomo II, pp. 559- 561; en M. Artola y R. Flaquer Montequi, II. La Constitución de 1812, ed. cit., pp. 206-207; y en I. Fernández Sarasola, Los primeros parlamentos modernos, ed. cit. Apéndice, doc. $\mathrm{n}^{\circ}$ 4, pp. 217-218. Para el proceso que de ahí arranca, vid. F. Suárez, El proceso de la convocatoria a Cortes (1808-1810). Pamplona, 1982; M. Morán Ortí, "La formación de las Cortes (1808-1810)", en M. Artola (ed.), Las Cortes de Cádiz [= Ayer, nº 1 (1991)]. Madrid, 1991, pp. 13-36 (con reedición, Madrid, 2003); y R. Hocquellet, "La convocatoria de las Cortes Extraordinarias de Cádiz (1808-1810), una etapa esencial de la revolución española”, en La revolución, la política moderna y el individuo. Jean - Philippe Luis (ed.). Zaragoza-Cádiz, 2011, pp. 107-140. 
damentales de los reinos y por los medios orientados a una mejora de la legislación, desterrando abusos y facilitando la perfección de toda ella, cuestión íntimamente ligada con la anterior. La problemática constitucional se reducía a una cuestión de simplificación y clarificación de todo el legado normativo de antaño. Si se desenmarañaban los múltiples nudos del Derecho, si se lavaba y mostraba su mejor imagen, aparecería la Constitución en todo su esplendor. Era, claro está, proceso de reforma a tenor del cuestionario, puesto que presuponía la existencia de esa Constitución, y nunca momento de ruptura revolucionaria, que quedaba neutralizada desde su arranque, dado que excluía alternativas o posibilidades políticas y jurídicas diferentes a las ya presentadas. En esa Consulta al País, se hallan informes, respuestas, documentos y dictámenes variados, heterogéneos, que exponen el pulso jurídico y político de España en ese año 1809. Es acaso una radiografía de lo que pensaban las principales instituciones del momento acerca de todo aquello que necesitaba la Monarquía para su refundación y para su subsistencia. El pensamiento mayoritario indicaba que había ya una Constitución, compuesta de varias Leyes Fundamentales, que se debía reinstalar a partir de su redescubrimiento, lo que implicaba reconocimiento y difusión hacia toda la Nación, para posteriormente proceder a dotarla de las medidas indispensables con las que asegurar su cumplimiento por toda la eternidad y así hacerla firme. Eran leyes inalterables que estaban situadas por encima de cualquier contingencia política, si bien era posible interpretarlas y así alterarlas, adicionarlas o explicarlas, por medio de las Cortes o contando con ellas. Nada nuevo respecto a lo que las nuevas y viejas instituciones habían estado diciendo desde el arranque del proceso revolucionario español allá por el mes de marzo de 1808. Las actas constitutivas de las Juntas, los documentos donde expresaban pareceres constitucionales o de otro signo, y los poderes y juramentos de sus miembros habían insistido en esa dirección constante, limitando así la capacidad de decisión de los sujetos comisionados actuantes. Retocar el edificio constitucional, pero no refundarlo. Ése era el sentir del momento.

En esta sede, en la citada Consulta, aparecerán -y no podía ser de otra forma- muchas referencias a la obra alfonsina, con marcada ambivalencia, distinguiendo entre su valor originario y las consecuencias derivadas de las mismas, puesto que las Partidas se presentan alternativamente como modelo de código claro, metódico, ordenado y simple, pero también, al contrario, como ejemplo de texto farragoso, complicado, obtuso y poco nacional, causante de la decadencia de la verdadera ju- risprudencia patria y de infinitas complicaciones jurisdiccionales y procesales. Martínez Marina y Sempere y Guarinos se combinan con naturalidad, como fuentes de las que beben los opinantes laicos y eclesiásticos. El clero es quien maneja tales cuerpos alfonsinos con una mayor recurrencia y fruición. En relación a la pregunta de los medios para defender tales Leyes Fundamentales, el arzobispo de Tarragona, por ejemplo, tras criticar las numerosas reformas legislativas de los tiempos inmediatamente anteriores, dice que en nuestras sabias leyes de Partida y otras antiguas de que se hacía poco uso, se hallará cuanto sea conducente al bien espiritual y temporal 
de la nación ${ }^{126}$. La obsesión normativa era crear un Código, no en sentido moderno, ilustrado y racional, sino bajo la forma de recopilación mejorada, simplificada, sistemática, para lo cual el precedente alfonsino podía servir como texto idóneo a tales propósitos, si bien con adaptaciones necesarias a las nuevas exigencias ${ }^{127}$. El nuevo texto legal así fraguado permitiría un mejor conocimiento de la legislación en su conjunto sin pretensiones uniformadoras, así como de la Constitución y de nosotros mismos como cuerpo político. No se olvide que el problema constitucional no era de perfección (dado que la Constitución ya lo era), sino de falta de uso, ignorancia y desconocimiento, querido o no, de aquella vieja tradición. Si se adaptaba a los tiempos, si se traducía al lenguaje moderno, se lograría recuperar aquélla de forma inmediata y se procedería a su realización con todos los beneficios públicos y privados que ello implicaba. El modelo para forjar un solo código debería ser, expone el obispo de Calahorra, la famosa y nunca bastantemente ponderada obra de las Partidas, tanto por su excelencia como por ser un monumento glorioso de nuestros mayores, anotando al pie de sus títulos y leyes las que el tiempo ha manifestado conducentes y las que las circunstancias del día ofrezcan necesarias ${ }^{128}$. Legado alfonsino, sí, pero pertinentemente adaptado a los tiempos con adiciones y con eliminaciones, incluso tomando en consideración otras experiencias constitucionales hispánicas, como la aragonesa u otras peninsulares, dado que el código ansiado no tenía que suponer cancelación de los viejos fueros, sino, antes bien, reafirmación de todos ellos en tanto en cuanto partes de un orden tradicional reivindicado ${ }^{129}$. Leyes Fundamentales las tenemos muy justas y sabias, en opinión del obispo de Orihuela, proponiendo formar con todas ellas un claro y breve cuerpo que se llame Constitución, Código o Instituciones de España e Indias, el cual sirva de precisa pauta y única regla a los jueces y letrados, cuya dificultad, que a los unos y a los otros se ofrezca, deberá juzgarla y definirla el príncipe como supremo legislador y a ésta se deberá estar sin que quede otro re-

${ }^{126}$ Cfr. M. Artola, Los orígenes de la España contemporánea, ed. cit. Tomo II, p. 130.

${ }^{127}$ Guardando congruencia, una vez más, con el legado ilustrado, como ha expuesto. B. Clavero, "La idea de código en la Ilustración jurídica”, cit., pp. 74-88. Completa esta visión recientemente M. Bermejo Castrillo, "Primeras luces de codificación. El Código como concepto y temprana memoria de su advenimiento en España", en $A H D E, \mathrm{n}^{\circ} 83$ (2013), pp. 9-63.

${ }^{128}$ Cfr. M. Artola, Los orígenes de la España contemporánea, ed. cit. Tomo II, p. 144.

${ }^{129}$ El ejemplo por antonomasia es A. Capmany, quien invoca los fueros de Aragón, Valencia, Cataluña y Navarra, pero también a las Provincias Vascongadas y al Principado de Asturias, para poner de relieve que antes que Constitución española, la Historia nos suministra varias Constituciones peninsulares. Cfr. J. Álvarez Junco, "Capmany y su informe sobre la necesidad de una Constitución (1809)", en Cuadernos Hispanoamericanos, $\mathrm{n}^{\mathrm{o}} 210$ (junio, 1967), pp. 520-551. Lo publica asimismo M. Artola, Los orígenes de la España contemporánea, ed. cit. Tomo II, pp. 509-528, específicamente, p. 525. También reivindican ese Derecho no castellano el obispo y cabildo de Córdoba o el obispo de Teruel, por ejemplo. Cfr. M. Artola, Los orígenes de la España contemporánea, ed. cit. Tomo II, p. 167-169 y p. 219 (=Cortes de Cádiz. I. Informes oficiales sobre Cortes. Andalucía y Extremadura, ed. cit., pp. 217 ss.; y Cortes de Cádiz. I. Informes oficiales sobre Cortes. Valencia y Aragón, ed. cit., pp. 309 ss., respectivamente). 
curso $^{130}$. Es el obispo de Urgel quien primero realiza una enumeración de los cuerpos normativos donde se halla esa Constitución histórica ${ }^{131}$. Un particular, Pedro Alcántara y Corrales, hace lo propio desde Málaga con coincidencia en líneas generales respecto al prelado catalán ${ }^{132}$. Lo mismo sucede con el informe remitido por la Audiencia de Valencia ${ }^{133}$. Por supuesto, en todos estos casos, la obra de Alfonso X figura en un lugar privilegiado, capital, clave. Simplificación pide el cabildo de Segorbe, reite-

${ }^{130}$ Cfr. M. Artola, Los orígenes de la España contemporánea, ed. cit. Tomo II, p. 218 (= Cortes de Cádiz. I. Informes oficiales sobre Cortes. Valencia y Aragón, ed. cit., pp. 75 ss.).

${ }^{131}$ Cfr. M. Artola, Los orígenes de la España contemporánea, ed. cit. Tomo II, pp. 221-222: “Entiendo, pues, al intento por leyes fundamentales del reino las generales que el reino ha publicado en los cuatros estados de legislación que ha tenido desde Alarico, por sus muchos, repetidos y diversos códigos, ya puramente civiles, ya como canónicos, a saber: el primero, de Concilios o de Comicios de ambas potestades; el segundo de fueros generales y municipales; el tercero y más fundamental y seguro, de las Cortes, y el cuarto, el de Decretos Reales, Pragmáticas, Cédulas y Cartas o Autos Acordados, más de ministros, soberanos y libres y de tribunales dependientes, por desgracia, de sus antojos arbitrarios y sistemas interesados de opinión, que de reyes y de reinos. Por consiguiente, entiendo que el Fuero Juzgo, los Concilios de Toledo, los Capitulares de Carlo Magno, las Siete Partidas, el Estilo, los Ordenamientos, los fueros generales, la nueva y novísima Recopilación, y sobre todo las Cortes celebradas desde principios del siglo XI por los Reyes Sanchos, Alonsos, Fernandos, Juanes, Enriques, Carlos y Felipes y las más célebres de Burgos, León, Coyança, Jaca, Señoríos de Molina, Lara y Vizcaya, Naxera, Benavente, Palencia, Alcalá, Avila, Valladolid, Briviesca, Toro, Guadalajara, Tordesillas, Sepúlveda, Toledo, Sevilla y Madrid, contienen las leyes fundamentales del reino". Estos son los cuerpos, pero sobre ellos hay que aplicar las indicaciones siguientes, en pp. 222-223, respecto a conocimiento, simplificación, orden y adaptación, fundiendo, purgando y acrisolando la inmensa legislación de España, para dar a luz un código de sus Leyes Fundamentales antiguas y modernas. Cfr. a este respecto la enumeración que efectúa la Comisión de Constitución en su Discurso Preliminar, ed. cit. [Parte I], p. 75.

${ }^{132} \mathrm{Cfr}$. M. Artola, Los orígenes de la España contemporánea, ed. cit. Tomo II, pp. 450 ss., con una enumeración parecida, aunque más simplificada, en p. 465: "Los cuerpos de nuestra legislación son el Fuero Juzgo, el Viejo de Castilla, el Real, las leyes de Partida, las del Estilo, el Ordenamiento Real, el de Alcalá, la Nueva Recopilación, la Novísima y Pragmáticas. A ellos han de agregarse los diversos fueros particulares que se concedieron a ciertas ciudades y pueblos y los que por privilegio rigen en Aragón, Navarra, Cataluña y Señorío de Vizcaya", con un buen conocimiento de su articulación, en pp. 466-467, pero sin olvidar la imperiosa necesidad de un Código breve, claro y sencillo que contenga todo cuanto pueda desearse, tomando como modelos a Teodosio y a Justiniano. Cfr. a este respecto conforme a lo indicado en la nota anterior.

${ }^{133}$ Cfr. Cortes de Cádiz. I. Informes oficiales sobre Cortes. Valencia y Aragón, ed. cit., pp. 25 ss., especialmente, pp. 45-48, con mención de Concilios toledanos, Fuero Juzgo, Fuero de Sepúlveda, Fuero Viejo, Fuero de León, Concilio de Coyanza, Fuero Real, colección que, apetecida por los pueblos y establecida en Cortes, hizo olvidar los fueros antiguos "y preparar a la nación con dulzura para recibir pacíficamente la gran mudanza que había de introducir en el Gobierno y en a administración pública la insigne compilación de las Siete Partidas, que de orden de su padre San Fernando, la emprendió en 1251 y puso fin a ella siete años después, como lo atestigua su prólogo", cuerpo metódico y el más completo de los conocidos en Europa, "para su formación se consultaron las costumbres, usos y fueros de la nación, se tuvieron a la vista aquellas leyes del derecho romano que más se conformaban con las claras luces de la razón y con el derecho de las gentes, y de su resultado se ha reconocido con admiración de los siglos un Cuerpo legislativo en que se ve brillar la sabia justicia y el orden imparcial para hacer feliz la Nación”. Cfr. a este respecto con arreglo a lo indicado en las dos notas anteriores supra. 
rando discursos anteriores, aunque con un tono no tan encomiástico. Se acusa de cierta farragosidad, amplitud e ilegibilidad a toda la obra alfonsina: hay que evitar la multitud de las leyes, reduciéndolas a un código más breve y manejable que lo que hizo el emperador Justiniano de las romanas y nuestro Don Alfonso de las Partidas, tomadas por la común de aquéllas ${ }^{134}$. El cabildo de Tarragona invoca la Partida Segunda (P. 2, 1, 5) para poner de relieve la superioridad del rey sobre sus súbditos, sobre la Nación constituida, siendo V. M el corazón y la cabeza de todo el Reino, o de la Nación, no sea posible se alteren jamás las funciones de estas dos partes principales del cuerpo político de la Nación, en perjuicio de los demás miembros del mismo, al tiempo que hace una encendida defensa del Derecho tradicional respecto del cual se solicita, con un argumentación ya reiterada, conocimiento completo con extensión a prácticas procesales de los tribunales, además de simplificación y método uniforme para con todo ese material jurídico ${ }^{135}$.

No es sólo el estamento eclesiástico quien formula estas invocaciones a las Partidas y demás obras alfonsinas. La Audiencia de Galicia alega P. 2, 15, 3, para las cuestiones de la regencia y hace un arrebatado panegírico del Derecho patrio. Nosotros tenemos las mejores leyes del mundo, benéficas, amigas del orden y que aseguran la libertad civil, aunque conviene ordenarlas en un nuevo código legal, sencillo y metódico donde aparezca la ley en su propio aspecto y con su lenguaje casto y majestuoso (...) adaptable a la ilustración del siglo y a las costumbres y establecimientos del dia ${ }^{136}$. El Ayuntamiento de Palma de Mallorca reivindica el carácter santo y justo de las leyes y costumbres tradicionales, que deben ser adaptadas al país y conformarse al genio y al carácter nacional, con las Partidas en el horizonte como implícitamente se deduce de su exposición, en la que insiste en la defensa de la religión católica ${ }^{137}$. Para el Ayuntamiento de Yecla, las Partidas son Código casi perfecto, aunque la Constitución es otra cosa o, cuando menos, la Constitución Política, la cual habrá de hacerse de nuevo por medio de las Cortes. ¿Qué resta de la obra alfonsina? La parte civil de aquéllas se puede conservar, pero urge cambiar la criminal ${ }^{138}$. En términos

\footnotetext{
${ }^{134}$ Cfr. M. Artola, Los orígenes de la España contemporánea, ed. cit. Tomo II, p. 267 (= Cortes de Cádiz. I. Informes oficiales sobre Cortes. Valencia y Aragón, ed. cit., pp. 145 ss.).

${ }_{135}$ Cfr. M. Artola, Los orígenes de la España contemporánea, ed. cit. Tomo II, pp. 267-268.

${ }^{136}$ Cfr. M. Artola, Los orígenes de la España contemporánea, ed. cit. Tomo II, pp. 281-284.

${ }^{137}$ Cfr. M. Artola, Los orígenes de la España contemporánea, ed. cit. Tomo II, p. 319 (=Cortes de Cádiz. I. Informes oficiales sobre Cortes. Baleares, ed. cit., pp. 181 ss.).

${ }^{138}$ Cfr. M. Artola, Los orígenes de la España contemporánea, ed. cit. Tomo II, p. 326: “Desde el Código de las Partidas no tenemos uno que merezca este nombre; y si bien en la parte civil hay quizá poco que enmendar, s preciso hacer de nuevo la criminar (si se exceptúa un corto número de excelentes leyes) por la diferencia de costumbres del tiempo en que se escribió al presente. Y así, después de formada la Constitución política, parece que el primer cuidado de este augusto cuerpo deberá ser la formación de un buen código criminal y en seguida el arreglo del civil, que quedará muy simplificado si se da por el pie, como es de esperar a muchas instituciones absurdas que le complican ahora y son otros tantos manantiales de interminables litigios".
} 
parecidos se manifiestan la Junta de Mallorca o la Junta de Trujillo ${ }^{139}$. Los particulares consultados o que libremente brindaron sus opiniones a la Junta Central siguen en esta dirección que nos muestra, pues, el sentimiento de presencia y de pertenencia de esa obra alfonsina dentro del cuerpo constitucional general, modelo, ejemplo o base indispensable de todas las construcciones jurídicas renovadoras que se quisiesen idear a partir de entonces ${ }^{140}$. Alguna crítica más exaltada, como la de Borrull, comparece, pero son las menos ${ }^{141}$. El elogio es la regla general. Su modélico método y configuración prevalecen sobre las voces discordantes mínimas que se empeñan en negarle tal caracterización. Es arquetipo de orden y estabilidad dados y prototipo para organizar y reorganizar el Derecho construido a lo largo de siglos. Usando términos teológicos, las Partidas son orden ordenado y también orden ordenador, al mismo tiempo. Es además texto vivo y empleado, muchas veces como cita erudita que acompaña, engalana y adorna, pero otras veces con mayor recorrido y mayor contenido de fondo, es decir, como elemento de alegación política y jurídica, como texto vigente, combativo, invocado en cualquier debate del que se trate. Lo que es indiscutible es su adscripción a la Constitución histórica, su pertenencia al catálogo de las Leyes Fundamentales de la Monarquía, su carácter esencial para la estructura político-jurídica del reino. Ése es el parecer mayoritario de la Nación.

De las varias Juntas que se encargaron de asesorar a la Comisión de Cortes para disciplinar toda la convocatoria puesta en marcha en mayo de $1809^{142}$, hay una que

${ }^{139}$ Cfr. M. Artola, Los orígenes de la España contemporánea, ed. cit. Tomo II, pp. 349-350 (= Cortes de Cádiz. I. Informes oficiales sobre Cortes. Baleares, ed. cit., pp. 109 ss.); y pp. 356-368, hablando de las Partidas como nuestro Código más metódico y completo, "en el que se echaron los cimientos sobre que por lo común se ha venido edificando".

${ }^{140}$ Cfr. M. Artola, Los orígenes de la España contemporánea, ed. cit. Tomo II, pp. 400 ss. (Ramón Lázaro de Dou), pp. 421 ss. (Fray José de Jesús Muñoz), pp. 436 ss. (José Sala), pp. 474 ss. (Fernando Andrés Benito), con rechazo de convocatoria de las Cortes con arreglo a Fuero Juzgo, Real, Partidas, Fueros de Aragón o Recopilación, pp. 496 ss. (Francisco de Borja Messeguer), pp. 571 ss. (José Solsona), pp. 595 ss. (José Manuel Vadillo), pp. 609 ss. (José Batlle y Jover), pp. 620 ss. (Manuel Fernández Manrique), pp. 645 ss. (Antonio Panadero), y pp. 662 ss. (Julián Romero y López).

${ }^{141}$ Cfr. M. Artola, Los orígenes de la España contemporánea, ed. cit. Tomo II, pp. 505-509: "La legislación de Castilla (como lo fue la de Roma después de viciada la República) es inmensa, habiéndose multiplicado hasta el exceso, con tantas órdenes sueltas y los diferentes códigos de recopilación, de fueros y de Partidas, que sirven de confusión y ocasionan muchos pleitos (...) Y se compone de unos códigos que deben reformarse enteramente: el de las Partidas, por estar lleno de establecimiento de los antiguos romanos y de otros que no son adaptables a estos tiempos; el del Fuero Real, por contener muchos de los últimos, y el de la Novísima Recopilación, por ser una ruda e indigesta mole de leyes sueltas con los referidos defectos, no observar el método correspondiente y dirigirse a borrar de la memoria de las gentes las leyes fundamentales del Reino, insertando no la primitiva, sino la del año 1713, que está derogada, y para asegurar el despotismo y privar si podía la nación de sus legítimos derechos, omitió las leyes que había en las Recopilaciones anteriores, la primera y segunda, tít. $7^{\circ}$, lib. $6^{\circ}$, que disponían que sin consentimiento de las Cortes no pudieran establecerse tributos y que los hechos grandes y arduos del reino se determinarán con consejo de las mismas, por cuyos criminales defectos debía recogerse y quemarse dicha Recopilación y castigar a su redactor y aprobantes". ${ }^{142}$ Cfr. F. Suárez, El proceso de la convocatoria de Cortes, ed. cit., pp. 185 ss. Las restantes Juntas eran 
destaca por encima de las demás y que gozará de una protagonismo exclusivo en cuestiones constitucionales o de Leyes Fundamentales: la Junta de Legislación, radicada en Sevilla y actuante desde el verano de 1809 hasta finales de enero de 1810. La integran Riquelme, como presidente, Manuel de Lardizábal, el conde del Pinar, José Pablo Valiente, Antonio Ranz Romanillos, Alejandro Dolarea, José María Blanco White (sustituido por Antonio Porcel al poco tiempo) y Agustín de Argüelles, como secretario con voz y voto ${ }^{143}$. La razón de ser de la misma era muy sencilla: si la labor de las Cortes era debatir sobre las Leyes Fundamentales para proceder a su reimplantación o reinstauración, además de a su mejora o corrección, en un equilibrio entre estática y dinámica constitucionales, lo primero que tenía que saberse era cuáles eran tales leyes y dónde se podían encontrar, cuál era su contenido, cómo habían logrado pervivir y por medio de qué textos. En suma, había que averiguar qué eran, cuáles eran, dónde estaban radicadas $\mathrm{y}$, con ellas, la propia Constitución que las aglutinaba a todas sin excepción. Ni la Ilustración con su pléyade de pensadores, ni los nuevos poderes surgidos de la descabezada Monarquía habían conseguido dar una satisfactoria respuesta, una formulación precisa, exacta y detallada a este interrogante, lo que no era cuestión menor porque el destino de las Cortes y de la Nación misma dependía de esta contestación. El tipo de Cortes, sus atributos y sus competencias precisaban de una investigación en clave histórica para determinar cuál sería su esencia y cuál su afán. Lo mismo sucedía con el propósito o trabajo principal de esas Cortes: si había que restaurar la Constitución histórica, ¿dónde se hallaba ésta? Si ésta se desglosaba en varias Leyes Fundamentales, ¿cuáles eran? La Junta de Legislación trató de responder a estas dudas constitucionales dentro de la más estricta ortodoxia y sin apartarse del guión marcado. Sin ser miembro de la misma, Jovellanos redacta una famosa Instrucción en la cual exponía cuál debía ser su actividad de futuro, lo que marcó indefectiblemente su devenir inmediato y los resultados de aquella labor de investigación pertinentemente dirigida ${ }^{144}$. Tal documento es prueba fehaciente además de que

la de Ordenación y Redacción, la de Medios y Recursos, la de Hacienda, la de Instrucción Pública, la de Materias Eclesiásticas y la de Ceremonial.

${ }^{143}$ La Junta de Legislación se crea el 27 de septiembre de 1809, celebra su primera sesión el 4 de octubre, y se disuelve, casi a la par que la Junta Central, de la cual traía causa, el 19 de enero de 1810. Su actuación es explicada con detenimiento por F. Tomás y Valiente, "Génesis de la Constitución de 1812", cit., pp. 76 ss. (= ahora reeditada por Urgoiti Editores, en su Colección Historiadores, $\mathrm{n}^{\circ}$ 15, con prólogo de M. Lorente Sariñena. Pamplona, 2011). Sus acuerdos son publicados por el mismo, en art. cit., pp. 103125, por donde se cita. Los edita también I. Fernández Sarasola, Proyectos constitucionales en España, ed. cit., pp. 643 ss.

${ }^{144}$ Cfr. M. Artola, "El pensamiento político de Jovellanos según las instrucción inédita a la Junta de Real Hacienda y Legislación", en Archivum. Revista de Facultad de Filología, nº 12 (1962), pp. 210216 (= asimismo reproducida en M. Artola y R. Flaquer Montequí, La Constitución de 1812, ed. cit., $\mathrm{n}^{\circ}$ 41, pp. 292-295; y en G. M. de Jovellanos, Obras completas iniciadas por José Miguel Caso González. Tomo XI. Escritos políticos, ed. cit., pp. 263-270). Se inserta también en el acta de la primera sesión de la Junta de Legislación, nombrada por la Comisión de Cortes, celebrada en Sevilla el 4 de octubre de 1809, como transcribe F. Tomás y Valiente, “Génesis de la Constitución de 1812”, cit., pp. 103-106. No 
la idea anteriormente expuesta, la de que España como Monarquía poseía una Constitución y una parte relevante de la misma la formaban las obras alfonsinas, especialmente las Partidas, tenía sustantividad propia y era compartida por la mayor parte de la intelectualidad del momento ${ }^{145}$. La Instrucción del asturiano, reveladora como la que más de su pensamiento constitucional y asimismo de lo que se estaba haciendo

deja ser traición al subconsciente que Jovellanos hable a posteriori de la Junta de Constitución y de Legislación en su Memoria en defensa de la Junta Central (1811). Parte Segunda. Exposición de la conducta y opiniones del autor, en Obras completas iniciadas por José Miguel Caso González. Tomo XI. Escritos políticos, ed. cit., p. 513, puesto que constitucional era su tarea proyectada y ejecutada. Aunque también es sabedor, desde la distancia, de que la labor de las Cortes de Cádiz es criticable por apartarse precisamente del modelo histórico de templanza y moderación, y aproximarse al temido patrón asambleario francés con un ejecutivo debilitado y unas Cortes con poderes cuasi absolutos y sin frenos, es decir, constata que las Cortes se están equivocando y están pergeñando algo que se separa de la Historia, aunque con la ansiada posibilidad de volver a la misma, como de hecho se hará al redactar la Constitución. Pone de manifiesto esa crítica en sendas cartas a Lord Holland y al marqués de Villanueva del Prado, casi al final de su vida, en G. M. de Jovellanos, Obras Completas. Tomo V. Correspondencia. $4^{\circ}$. (Octubre, 1808-1810). (Addenda). Edición crítica, introducción y notas de José Miguel Caso González. Oviedo, 1990, $\mathrm{n}^{\circ}$ 2.039-2.039bis. De Jovellanos a Lord Holland (Muros, 5 de diciembre de 1810), pp. 421-428, $\mathrm{y} \mathrm{n}^{\circ}$ 2.040. De Jovellanos al marqués de Villanueva del Prado (Muros, 29 de diciembre de 1810), pp. 429-432.

${ }^{145}$ Consecuencia, casi simultánea, de esto es la Memoria relativa a la Instrucción de la Comisión de Cortes referente a la formación de un sistema general de Hacienda, de 30 de octubre de 1809, en M. Artola y R. Flaquer Montequí, II. La Constitución de 1812, ed. cit., pp. 290-292, donde se habla del carácter políticamente esencial de las Cortes y del gobierno monárquico moderado. No muy distinto es el parecer de la Junta de Ceremonial, de 5 de diciembre de 1809, o el del Consejo de España e Indias, de 22 de diciembre de 1809. Cfr. M. Fernández Martín, Derecho parlamentario español. Madrid, 1992. Tomo I, pp. 539-544 y pp. 549-566 (= también en M. Artola y R. Flaquer Montequí, II. La Constitución de 1812, ed. cit., pp. 227-230 y 231-242). La primera afirmaba con rotundidad: “iQué dulce placer el de trabajar en la reparación del augusto edificio de nuestra Constitución, socavado ya por el tiempo y por los continuos embates de quantos han tenido interés en arruinarlo!". La respuesta de la Comisión de Cortes, el 18 de diciembre de 1809, incide en esta línea, en Derecho parlamentario español, ed. cit. Tomo I, p. 547: "Dirijamos, pues, todo nuestro empeño, y sea nuestro principal conato afianzar la Constitución monárquica sobre bases sólidas, de modo que al Rey le quede asegurada su dignidad y prerogativa real, expedito y libre su poder, al clero y nobleza confirmada su existencia política, enlazándola con la del pueblo, y formando de todas un apoyo en que se sostengan firme y poderosamente los derechos imprescriptibles del pueblo mismo". Por su parte, ese nuevo Consejo aludido propugnaba "el sostener con celo y fidelidad la conservación de la religión y de la Patria, y los derechos del Monarca, que ha jurado con la obediencia á las leyes, y loables costumbres de la Nacion, mientras que por la autoridad legítima no se hagan otras", "se deberá tratar, resolver, y executar una Constitucion conforme á nuestras Leyes fundamentales con las mejoras, enmiendas, y adicciones que en lo posible la perfeccionen, mas no la destruyan", sin concesiones a Francia, ya que "debe, pues, conservarse nuestra constitucion religiosamente, meditando con prudencia aquellas precauciones que sin trastornarla la hagan más sólida, más robusta y más firme contra los abusos é influxos de los privados iniquos que rodean á los Soberanos y se aprovechan de su bondad ó imbecilidad para oprimir á los vasallos". En idéntico sentido, cfr. el Dictamen de la Comisión de Cortes, de 8 de enero de 1809, en Derecho parlamentario español, ed. cit. Tomo I, pp. 590-599; y en M. Artola y R. Flaquer Montequí, II. La Constitución de 1812, ed. cit., pp. 254-260; y lo mismo podemos decir del Manifiesto de la Junta Central, de 28 de octubre de 1809, de nuevo en M. Fernández Martín, Derecho parlamentario español, ed. cit. Tomo II, pp. 562-570. 
desde la Junta Central y desde sus órganos satélites, planteaba una primera ordenación en bloques generales de todas aquellas Leyes Fundamentales, de las que todo el mundo hablaba, que nadie había visto y que comenzaban a vislumbrarse por parte de los hombres públicos del momento a fin de resolver una enigma de siglos. Al mismo tiempo que gestaba este esquema organizativo, se procedía a determinar el modo de actuación que habría de conducir el comportamiento de las Cortes, es decir, qué deberían hacer en relación con todas estas Leyes Fundamentales, cómo dirigirse a ellas, y qué cosas no podían hacer con las mismas. La Junta de Legislación era la que respondería a la cuestión planteada en la Consulta acerca de meditar las mejoras que pueda recibir nuestra legislación, así en las leyes fundamentales como en las positivas del reino y proponer los medios de asegurar su observancia. Dos campos de actuación se planteaban, por tanto, para la Junta de Legislación: el de las Leyes Fundamentales, el más relevante y jerárquicamente más elevado y sublime, y el de las Leyes Positivas, de menor enjundia, en tanto que subordinadas a las anteriores y supeditadas a las mismas. Las primeras integran la Constitución y de ahí derivan todas las demás, las llamadas positivas, divididas en civiles, criminales, las de policía interior y las mercantiles. Respecto a las fundamentales, lo que se ha de hacer con ellas, de conformidad con un sentimiento ya expresado por la Nación y por sus cuerpos en tiempos inmediatamente recientes, es reunirlas con el objeto de clarificarlas y para ello se dan indicaciones sistematizadoras que las agrupan en cinco categorías: derechos del soberano, derechos de la Nación considerada como cuerpo social, derecho de los individuos como miembros y partes constituyentes de la sociedad, las referidas a la esencia y a la forma de gobierno, y las concernientes al derecho publico interior de España. Hecha esta primera delimitación de los rubros constitucionales básicos, se añaden unas pautas de actuación subsiguientes, de no menor importancia y calado. Reunidas y ordenadas todas estas normas, esto es, clasificadas y clarificadas hasta sus últimos extremos, la Junta debería examinar y proponer los medios indispensables que asegurasen su observancia, tanto frente al poder arbitrario ejercitado sobre los derechos de la Nación y de sus miembros, como frente a los ataques a los derechos legítimos del soberano, poniendo de manifiesto, una vez más, la dualidad política imperante con una Nación y una Monarquía que van a la par. Así, se lograrán afirmar derechos y libertades, y también afirmar mecanismos de tutela de los mismos. Dos acciones ulteriores y remotas, que eventualmente pueden no comparecer, es decir, que pueden no ser necesarias dependiendo de los supuestos de hecho, completan el quehacer de la Junta: exégesis y renovación. Algunas de esas leyes podrían necesitar aclaración o declaración, por todo lo cual la Junta ha de aprestarse a realizar esa tarea hermenéutica y decir qué significa ésta o aquella ley en el nuevo contexto político. Del mismo modo, si se tiene constancia de la necesidad de alguna nueva disposición legal de este tipo, en orden a la perfección de nuestro sistema constitucional, se hará saber, si bien es preciso un examen detallado de la nueva norma propuesta para que sean siempre conformes al espiritu de las ya establecidas, con el propósito de eludir 
disonancias, $\mathrm{y}$, al mismo tiempo, deben ser esas normas nuevas pocas y claras para que su observancia sea más segura, con lo que se eluden los riesgos de una radical innovación. Ésta procede, es admitida, pero dentro de los esquemas proporcionados por las normas ya existentes, por la Constitución ya dada. Jovellanos pide finalmente uniformidad para esa labor constitucional, tanto en lo referido al gobierno interior de los pueblos y provincias como en lo relativo a las obligaciones y derechos de sus respectivos habitantes. Eso es lo que deberían hacer la Junta y, por elevación, las Cortes convocadas, a partir de y en desarrollo del trabajo de aquélla.

En suma, la Junta de Legislación tenía como cometido fundamental hacer lo que se echaba en falta en al panorama constitucional desde hacía tanto tiempo: frente al silencio, la ocultación, el desconocimiento y la ignorancia, debía determinar cuáles eran expresamente esas Leyes Fundamentales, es decir, buscar en los principales cuerpos jurídicos de nuestro Derecho patrio cuáles eran los preceptos exactos a los que se podía otorgar el calificativo de fundamentales y obrar en consecuencia para con los mismos, procediendo a la reconstrucción de la Monarquía desde sus propios principios, dentro del respeto a esos dogmas previos, a esa ortodoxia capital indiscutida: ordenando, asegurando, explicando y completando lo existente, pero no innovando, subvirtiendo, cambiando a la ligera, desplazando o suplantando el tradicional espíritu constitucional, decantado por el paso de los siglos e indisponible para el común de los mortales. Todas las bibliotecas y archivos públicos de Sevilla quedaban a la entera disposición de la Junta y de cada uno de sus miembros para poder consultar, extractar y si fuere necesario extraer temporalmente, cuantos volúmenes, códices, manuscritos e instrumentos públicos tengan relación no sólo con los Cuerpos del Derecho Español en general, sino también con los fueros municipales de Provincias y Ciudades, y así mismo cuanto pertenezca a la celebración y peticiones en Cortes. Su trabajo final, el de la Junta de Legislación, quedará explicitado en la labor de Antonio Ranz Romanillos, uno de sus miembros más activos, ambiguo personaje que tiene protagonismo antes, durante y después de las Cortes de Cádiz, a quien se debe la más que probable autoría del Proyecto Constitucional que se debatió en las Generales y Extraordinarias por medio de su Comisión de Constitución. Aquella Constitución histórica y sus Leyes Fundamentales, a lo que parece, habían hecho su aparición y se habían expresado sus normas esenciales. Diversos acuerdos de la Junta van avanzando soluciones en clave constitucional pretérita, a medida que se investigaba y se leían textos antiguos, planteando alguna duda casi constituyente como sucede en la Sesión del 5 de noviembre de 1809 , pero sin ir más lejos en su cometido, dado que lenguaje y consecuencias del mismo seguían moviéndose dentro del marco intocable del Constitucionalismo histórico tradicional ${ }^{146}$.

${ }^{146}$ Así, cfr. $5^{\circ}$ Acuerdo (Sesión de 29 de octubre de 1809); $6^{\circ}$ Acuerdo (Sesión de 5 de noviembre de 1809), con Apéndice firmado por Antonio Ranz Romanillos, planteando varias dudas a resolver por la Junta en orden a recuperar la observancia y asegurar la ejecución de las Leyes Fundamentales; $13^{\circ}$ Acuer- 
Acaso el momento central de este proceso de recuperación constitucional lo conforma la Sesión de 10 de diciembre de 1809, en cuyas actas consta como adjunto un informe de Ranz Romanillos, de nueve folios, en el que se detallan cuáles eran, por fin, aquellas Leyes Fundamentales, en la senda indicada por Jovellanos, aunque con algunos cambios, no del todo neutrales o pacíficos, y con algunas observaciones complementarias bastante relevantes respecto a poderes públicos y Constituciones alternativas a las que se podía recurrir para mostrar en su plenitud ese orden fundamental ${ }^{147}$. El cambio más notorio y evidente consistía en anticipar los derechos de la Nación frente a los del Rey, lo cual se pudiera deber a la propia situación que España vivía en aquel instante con Nación actuante y monarca ausente, antes que a cualquier otra lectura liberal. En todo caso y esto es lo verdaderamente relevante, la nómina de Leyes Fundamentales confiere un lugar privilegiado a los textos alfonsinos. Alfonso X recupera parte de su esplendor antiguo y se expresa en términos constitucionales casi modernos, anticipando muchas creaciones posteriores al Medievo. El pasado se traslada al presente y se apropia de los conceptos contemporáneos. Manejando los cuerpos normativos tradicionales de Castilla y León, núcleo de una pretendida Constitución hispánica, Ranz Romanillos presenta una primera parte dedicada a los Derechos de la Nación, donde comparecen nueves leyes de las Partidas, a saber, P. 1, 1, 16, P. 1, 1, 17 y P. 1, 1, 18, sobre el rey legislador y la cuestión de la obediencia a las leyes; P. 1, 2, 8, sobre cómo deben hacerse los fueros; P. 2, 1, 1, acerca de la dignidad del emperador y del rey; P. 2, 1, 10, para diferenciar entre rey y tirano; P. 2, 13, 19, para el entierro del rey; P. 2, 15, 3, sobre regencia establecida cuando el rey es menor o ha perdido el juicio; y P. 2, 15, 5, con la prohibición de enajenar o partir el señorío del monarca. Para los Derechos del Rey, el elenco manejado es mucho mayor puesto que se incorpora el Fuero Real. Así, comparecen cuatro leyes del citado Fuero regio [FR. 1, 2, 1 (pena a los que ofendan al rey de hecho o de palabra, y a los que van contra su señorío); FR 1, 3, 1 (muerte del rey y homenaje a su sucesor); FR $1,7,1$ (sobre juramento que los alcaldes han de prestar al rey y poder normativo de éste); y FR. 4, 21, 5 (acerca de rieptos, desafíos y otras manifestaciones del poder real)], y ocho leyes de las Partidas, especialmente, de la segunda de ellas [P. 1, 1, 12

do (Sesión de 15 de diciembre de 1809); $15^{\circ}$ Acuerdo (Sesión de 17 de diciembre de 1809); $16^{\circ}$ Acuerdo (Sesión de 29 de diciembre de 1809); $17^{\circ}$ Acuerdo (Sesión de 31 de diciembre de 1809); $18^{\circ}$ Acuerdo (Sesión de 5 de enero de 1810); y $1^{\circ}$ Acuerdo (Sesión de 7 de enero de 1810). Cfr. F. Tomás y Valiente, “Génesis de la Constitución de 1812”, cit., pp. 108, 109-110, 120, 120-121, 121-122, 122-123, 123 y 123-124, respectivamente.

${ }^{147}$ Cfr. $12^{\circ}$ Acuerdo (Sesión de 10 de diciembre de 1809). Cfr. F. Tomás y Valiente, "Génesis de la Constitución de 1812", cit., pp. 113-118. También publican esta Reunión de las leyes fundamentales de la Monarquía Española clasificadas por el método que prescribe la Instrucción formada por la Comisión de Cortes para arreglar y dirigir los trabajos de la Junta de Legislación en los párrafos $7^{\circ}$. y $9^{\circ}$, S. M. Coronas González, "Las Leyes Fundamentales del Antiguo Régimen”, cit., pp. 213-218 (=Estudios de Historia del Derecho Público, ed. cit., pp. 311-321); e I. Fernández Sarasola, Proyectos constitucionales en España, ed. cit., pp. 664-673. 
(sobre el poder de hacer leyes); P. 1, 5, 18, P. 1, 6, 50 y P. 1, 6, 55 (sobre varias cuestiones canónicas: patronato, inmunidades, etc.); P. 2, 1, 8 (poderío del rey); P. 2, 13, 20 (sucesión del rey y honra de los principales del reino al sucesor); P. 2, 15, 2 (orden sucesorio del reino); y P. 2, 19, 3 (defensa del reino en caso de levantamiento interno contra el monarca)]. Finalmente, los Derechos de los Individuos se centran en cuestiones procesales y criminales, a modo de anticipadas garantías constitucionales de corte moderno, pensadas por y para el individuo particular, con tres leyes del Fuero Real (FR. 2, 3, 4; FR. 2, 8, 3; y FR. 4, 20, 12, sobre emplazamientos y fianzas, pruebas $\mathrm{y}$ testigos, y pesquisas del rey, respectivamente), en las que se llega a intuir el habeas corpus, y siete leyes de las Partidas (P. 2, 1, 2; P. 3, 17, 5; P. 3, 17, 11; P. 7, 1, 26; P. 7, 29, 4; P. 7, 29, 11; y P. 7, 31, 7), procedentes de la tercera y séptima, donde se desgranaba el funcionamiento del proceso en general (pesquisas, defensa de las partes con igualdad de armas y de informaciones) y, más en concreto, el del orden criminal y el régimen de las penas (cuestiones probatorias, certeza del juzgador, detenciones por orden del rey o del juez, custodia de los presos). La observación final de Ranz Romanillos deja abierta la puerta a un posible complemento o suplemento a esta Constitución aquí esbozada por la vía de la remisión a lo que había venido sucediendo en otros territorios de la Monarquía. Con estos mimbres, se ha construido a lo largo del tiempo una Monarquía templada, como lo era la de Castilla y León (y así se ha probado), pero también lo eran la de la extinta Corona de Aragón o la del Reino de Navarra, cuyas prácticas políticas (la constitución propia) estaban vigentes al tiempo del informe referido, mas como esto es tan sabido de todos, no se ha tenido por conveniente agregar a esta reunión sus leyes y fueros particulares, además de que hubiera sido obra inmensa. Lo que ha hecho Ranz Romanillos no es excepción sino regla: no difiere de lo que era un sentir generalizado, a tenor de los resultados de la Consulta al País ya mencionados. Era lo que se preveía o lo que se intuía desde la centuria anterior cuando esa Ilustración hispánica había capitaneado a sus pensadores en una expedición hacia el pasado para traer hasta su presente esa vieja Constitución, sin atarse a dogmas, a creencias o a conceptos antiguos. Se trataba de revisitar textos históricos, vivos y vigentes, con intención de hacer espeleología constitucional, tales como el Fuero Juzgo, el Fuero Viejo, el Ordenamiento de Alcalá, el Ordenamiento Real, la Nueva Recopilación o los Autos Acordados, amén de las obras alfonsinas ya mencionadas. Leyes, pasajes y fragmentos eran leídos e interpretados con marcada óptica política presentista, reivindicando el papel de las Cortes como auténtico órgano legislativo y reconociendo en ese pasado lo que semejaba novedad. Allí, en ese remoto y lejano tiempo, estaba ya contemplado todo lo que se quería recuperar para reconstruir un modelo político cuya eficacia venía contrastada y acreditada por su resistencia a Cronos. Los conceptos del presente se prefiguran en las prácticas del pasado, de suerte tal que se acaba por definir una Constitución sempiterna que ya tenía cabida en tiempos pasados. La Historia no traza fronteras, sino que integra dimensiones. No hay cesuras, no hay rupturas de ninguna clase y medida. El tiempo es un fluir continuo 
que nos lleva de un lado al otro sin complicaciones: de adelante hacia atrás y viceversa. Lo que había servido en tiempos medievales era lo que seguía sirviendo en tiempos modernos, por lo que no era preciso articular ningún cambio. Lo moderno, como tal, no tenía existencia autónoma: era el reflejo, la proyección, lo subsistente de lo antiguo, fraccionado, roto, y, en esos instantes específicos, en proceso de recomposición. Ése era el parecer de los hombres de aquel entonces, así lo creían, así lo pensaban y así actuaban. Desde ese preciso momento, se puede decir que quedaba clarificada la anciana Constitución y, sobre ella, sobre su rastro y sobre sus restos, a partir de la misma, es donde tendrían que operar la Cortes Generales y Extraordinarias, de las que me ocuparé a renglón seguido. Las convocatorias expedidas desde Sevilla a lo largo del mes de enero de 1810 no hacen más que certificar el contenido del trabajo aludido, la alta misión que ese nuevo Parlamento se preparaba a realizar y que no era otro más que esa revisión, adaptación y modernización de las antiguas Leyes Fundamentales ${ }^{148}$.

4. Puestas en funcionamiento las Cortes el 24 de septiembre de 1810, el acumulado teórico o doctrinal ya examinado deja sentir sus efectos, aunque de un modo más atenuado y suave, y, sobre todo, más contenido, en forma no tan exaltada y exuberante. Los tiempos de la pura reflexión ilimitada y del halago sin control han dejado paso a los de la prudencia y realidad políticas. El apasionado momento ideológico cede el testigo al frío momento técnico. Las Cortes gaditanas son un muestrario de ambigüedad, indefinición, falta de claridad, de lo que se sigue un carácter híbrido y vacilante respecto a las posibilidades de la revolución y a las realidades de la tradición, y acaso (todo lo anterior debido a la) falta de confianza en lo que se estaba haciendo (sobre todo, en aspectos constitucionales), dado que su división ideológica no fue tan nítida como se ha pretendido establecer, es decir, las facciones no estaban tan confrontadas y enfrentadas, al estilo de un Parlamento moderno, en contra de lo que se tiende a creer, y las matizaciones en el pensamiento de su protagonistas deben situarse a la orden del día. Los resultados de las votaciones, oscilantes, cambiantes, con mayorías

${ }^{148}$ Cfr. M. Fernández Martín, Derecho parlamentario español, ed. cit. Tomo II. Convocatoria para las Juntas Superiores, p. 571 Convocatoria para las ciudades con voto en Cortes, p. 572; Convocatoria para los Diputados de provincia, p. 573; y Convocatoria é intrucción especial para las elecciones por Canarias, p. 591, todas ellas del 1 de enero de 1810: las Cortes se reunirán para proteger la religión, para procurar la libertad del rey, para avanzar en la finalización de la guerra, y, sobre todo, "para restablecer y mejorar la Constitución fundamental de mis Reinos, en la cual se afiancen los derechos de Mi soberanía y las libertades de mis amados vasallos, y finalmente para resolver y determinar todos los asuntos que deben serlo en Córtes generales". En la Instrucción que deberá observarse para la elección de Diputados de Córtes, de la misma fecha, en ibidem, p. 574, se habla de "restablecer y mejorar una Constitución que sea digna de la Nacion española" (= también en M. Artola y R. Flaquer Montequí, II. La Constitución de 1812, ed. cit., pp. 242 ss.). En la Instrucción para las elecciones por América y Asia, de 14 de febrero de 1810, en ibidem, p. 599, se dice que el objetivo de las Cortes es "la restauración y recomposición de la Monarquía". 
que viene y van, comparecen y se disipan, son buena prueba de ello, en tanto en cuanto manifiestan la presencia entre los diputados gaditanos de un corpus de creencias homogéneo, separado o matizado por mínimas cuestiones secundarias que no afectaban al núcleo central de la fe política, al que se puede llamar su credo principal $^{149}$. Para conocer lo que allí se pergeñó nada mejor que la voz de sus protagonistas. Los Diarios de Sesiones, a los que ahora me referiré, recogen una parte del discurso político del momento, necesario para conocer de qué se hablaba, punto de partida inexcusable y, en ocasiones, único, por carencia de otros instrumentos exegéticos, pero no la fuente exclusiva de todo aquello de lo que se trató. Habría, pues, varios niveles que se deben integrar en el proceso de reconstrucción aproximativa del pasado al que toda Historia aspira: las propuestas y proyectos iniciales, el debate real en todos sus extremos, el debate reflejado en los Diarios, lo finalmente votado, aceptado y/o rechazado, lo que se publica, lo que se difunde, lo que se lee y se comprende por parte de cada destinatario, y lo que se ejecuta al final de este proceso ${ }^{150}$. La insuficiencia de tal fuente procede del hecho mismo de ser el vehículo de expresión de las Cortes, creación y criatura suya, y, por ende, difusor de lo que las Cortes querían que se supiese o se comunicase, y también de lo que no, pero nunca de la totalidad de lo debatido, de lo hablado o de lo votado. El filtro parlamentario censor operaba y operaba con contundencia y regularidad. Hay materiales que completan los debates parlamentarios (la prensa política del momento, sin ir más lejos), de la misma manera que las cuestiones aprobadas deben ser encuadradas en el contexto de un poder multiforme, fraccionado en múltiples autoridades, todavía dependiente de antiguos mecanismos de difusión del Derecho, que impedían de todo punto una divulgación uniforme de las normas que llegase a todo el mundo, aunque a todo el mundo alcanzase. La Constitución de 1812, la magna obra de las citadas Cortes, no ha de ser examinada solamente a la luz de lo que se dijo antes de ella, en sus momentos preparatorios previos, sino a través de lo que se dijo después de ella, a partir de su recepción, en las plurales exégesis a las que el texto constitucional dio origen y suscitó, careciendo, como se carecía entonces, de un mecanismo que permitiese lecturas e interpretaciones unifor-

\footnotetext{
${ }^{149}$ Vid. la bibliografía citada supra, en Parte Primera, nota $\mathrm{n}^{\circ} 48$, aunque con las reservas postuladas en el texto.

${ }^{150}$ El Diario era publicación oficial de las Cortes, a modo de un periódico más, generado con clara intencionalidad para ilustrar a la Nación y para encauzar o formar la opinión pública, pero también, en su calidad de obra oficial, un texto controlado por esas mismas Cortes que se reservaron la facultad de excluir del mismo todo lo que, a su juicio, fuese poco interesante, imprudente, excesivo, nocivo, etc. Lo que quiere decir que su fidelidad a lo que se dijo o trató en Cádiz tiene que ser observada con muchas reservas y complementada por otras fuentes y vías de conocimiento. Vid. las precisas y valiosas indicaciones de A. Fiestas Loza, "El Diario de Sesiones de las Cortes (1810-1814)", en AHDE, no 65 (1995), pp. 533-558. Siguen esta senda, M. Lorente Sariñena, "Los empleados de la redacción del Diario de Sesiones y la Colección de Decretos de las Cortes Generales y Extraordinarias", en Revista de Estudios Políticos. Nueva Época, no 93 (julio-septiembre, 1996), pp. 85-95; y R. Medina Plana, "El Diario de Sesiones del Trienio Liberal", en Cuadernos de Historia del Derecho, nº 9 (2002), pp. 29-120.
} 
mes y generalizadas, únicas para toda persona y para todo territorio, para toda autoridad y para todo particular. Las Cortes intentaron actuar como máximo, supremo y único intérprete de aquélla, pero su casuismo impidió labores globales y conclusiones que asimismo lo fueran, marcadas como estaba por esa insuficiencia soberana y nacional primera que condicionaba toda su actuación. Adoleció de generalidad, de respuestas completas, abstractas, erga omnes, extrapolables a todos los casos futuros. No había instrumentos nuevos para ello, que sirviesen a ese propósito asimismo novedoso, por lo que la incapacidad para romper tal círculo vicioso lastró la aparición de una auténtica labor de control de legalidad, convirtió en algo difuso y diluido el mismo propósito desde la perspectiva de la constitucionalidad y, con ello, evitó la irrupción de una Constitución plenamente moderna al carecer de medios, de fines y de presupuestos para que una tal idea hiciese su aparición incontestada ${ }^{151}$.

Operaron así como si fuesen uno de esos antiguos Consejos que asistían al monarca por medio de sus consultas reiteradas, avanzando como institución por medio de las dudas, inquietudes, propuestas y memorias que recibían de todo ciudadano y de todo poder público, y las consiguientes respuestas en uno u otro sentido que iban dando, si bien con una mayor capacidad de decisión que evitaba situar en el limbo del solo asesoramiento las acciones deliberativas tomadas por las mismas, a diferencia de lo que había acabado por suceder en relación al régimen polisinodial, ya en sus estertores, ahogado por sus propias contradicciones e imposibilidades derivadas de su ausencia de decisionismo puro. Habían conseguido las Cortes abrir la caja de Pandora de la novedad, quizás por la excepcionalidad del momento, $\mathrm{y}$, en todo caso, con un objetivo definido cual era el fortalecimiento del edificio constitucional monárquico del que se partía, nunca como poder constituyente pleno y puro, ni como poder legislativo omnipotente: las Cortes se comportaron como legislador, como legifactor, hicieron leyes e hicieron leyes nuevas, no simples declaraciones, si bien siguieron empleando en sus procedimientos los cauces usuales de los Consejos para forjar las normas correspondientes, y respetaron unos presupuestos de partida que daban sustento al perfecto orden universal donde se insertaban ellas mismas ${ }^{152}$.

${ }^{151}$ Hay, eso sí, una superioridad constitucional que viene determinada no por el valor en sí mismo considerado de la Constitución en cuanto que norma nueva, sino por el valor que la Historia ha dado a sus contenidos, a sus Leyes Fundamentales ahora revisadas y rearticuladas. La supremacía da como resultado un control difuso, dado que todo ciudadano puede presentar denuncias, quejas o peticiones indicando las infracciones constitucionales, que serán resueltas finalmente por las Cortes, pero sin crear reglas generales, sino de un modo casuístico y particular. Vid. M. Lorente Sariñena, Las infracciones a la Constitución de 1812, ed. cit., pp. 321 ss.

${ }^{152}$ Vid. F. Martínez Pérez, "Ley expresa, clara y terminante: orden normativo y paradigma jurisdiccional en el primer constitucionalismo español”, en Historia Constitucional, n 3 (junio, 2002), pp. 99-132; "Constitución de la Justicia en Cádiz. Jurisdicción y Consultas en el proceso constituyente de la potestad judicial”, en $A H D E, \mathrm{n}^{\circ} 81$ (2011), pp. 377-407; y “Constitucionalismo consultivo”, en Teoría \& Derecho. Revista de Pensamiento Jurídico, $\mathrm{n}^{\circ} 10$ (2011). La Constitución de 1812: miradas y perspectivas, pp. 89-99. 
Todo sucedió así porque las Cortes no se hallaron delante de la nada; se encontraron ante un sólido conjunto de cuerpos jurídicos, con un Derecho compacto, disperso, pero sólidamente asentado, real y efectivo, aplicado y vuelto a aplicar con regularidad, sin claras jerarquías o prelaciones, sobre el que se tenía que actuar con la conciencia y el convencimiento de que no era posible eliminarlo en su totalidad, sino edificar a partir de ese conjunto heterogéneo de textos ya establecidos. Abrogar o derogar no entraban en su vocabulario con la claridad conceptual y la sencillez aplicativa con que lo puede interpretar un jurista hodierno. Eran verbos que denotaban conceptos a utilizar sólo en casos excepcionales, muy puntuales y específicos, plenamente justificados por causa de pública utilidad o de necesidad general. El entramado normativo era algo que se aceptaba y se asumía, y, a partir del mismo, comenzaba por obra y gracia de las propias Cortes un proceso de construcción y de renovación de todo ese orden jurídico antiguo para edificar los famosos medios, precauciones y providencias que asegurasen para siempre la Constitución. Al Derecho nuevo que allí se gestará se llega partiendo del Derecho antiguo, algunas de cuyas partes no estaban sometidas a discusión y quedaban fuera de las ansias renovadoras. No se cancelaba el pasado en ningún instante, sino que se integraba, se adaptaba y se remozaba. No había llegado el tiempo todavía de una Codificación moderna con tales efectos drásticos y tales consecuencias profundas, ni, por supuesto, subyace ánimo constituyente alguno ${ }^{153}$.

Con arreglo al patrón de conducta trazado por Jovellanos y luego seguido desde instancias oficiales, ciertas normas históricas se reputarán fundamentales, y, por ende, intocables, y otras serán sencillamente positivas $\mathrm{y}$, en consecuencia, susceptibles de ser modificadas para asentar y garantizar las primeras, para servirlas. Las unas son indisponibles; las otras, pueden alterarse para servir a las primeras y hacerlas más fuertes, más sólidas, más duraderas. La nueva legislación, bajo forma de decretos, que arranca de las Cortes, implacable y omnímodo poder legislativo que fagocita a los restantes poderes, no se construye sobre el vacío, sino sobre un reverenciado caudal histórico, cuya influencia se deja sentir siempre. Aparece como parámetro para determinar la plena validez o el perfecto encaje jurídico de todo lo nuevo que va siendo objeto de aprobación. No hay ni remotamente un efecto derogatorio inmediato, ni tampoco una auténtica construcción legalista o legicentrista, que maximice el omnipotente papel de la ley como había sucedido en Francia, sino un pasado jurídico real y tangible, no de leyes, sino de Derecho encaminado a la Justicia, que condiciona de modo muy marcado lo que se hace en el tiempo presente. Aquel pasado no siempre comparece, no siempre hace sentir su voz, pero acaba por aflorar en la mayor parte de los supuestos examinados por el legislador. Constituye una suerte de legislación

\footnotetext{
${ }^{153}$ Para estas cuestiones, es referencia inexcusable P. Caroni, Lecciones catalanas sobre la Historia de la Codificación. Traducción castellana de Aquilino Iglesia Ferreirós. Barcelona, 1996; Saggi sulla Storia della Codificaczione. Milano, 1998; Escritos sobre la Codificación. Traducción de Adela Mora Cañada y Manuel Martínez Niera. Madrid, 2012; y Lecciones de Historia de la Codificación. Edición de Adela Mora Cañada y Manuel Martínez Neira. Madrid, 2013.
} 
subterránea que se activa cuando se rozan sus concretos límites y se tocan sus interioridades más sensibles, las fronteras de ese país pretérito. No se elimina, pues, la totalidad del Derecho ya conocido y formulado, sino que éste es invocado bajo la forma de leyes y hechos históricos, como Leyes del Reino o incluso como Constitución, en singular y sin el adjetivo de histórica, pues es la única que existe, la única que es real y que se ha dado, la única conocida y reconocida. Se recupera, se revisa y se incardina en una nueva dinámica que afectaba a lo actual. La nueva legislación se inserta en el seno de la antigua, como si se tratase de un injerto de algo novedoso en un tronco antiguo, recogiéndose finalmente un fruto radicalmente distinto que no se parecía a uno, ni a otro, porque los modos de relación y articulación entre ambas dimensiones seguían siendo los convencionales. Los diputados gaditanos obraron con suma prudencia, al mejor estilo de los juristas de la época, acaso porque la idea de ley que tenían en mente no era la de algo creado por alguien, sino la vieja y católica noción de algo declarado o confirmado a partir de un orden previo existente. La cosmovisión religiosa extendía sus tentáculos más allá del mundo jurídico, precisamente porque esa cosmovisión afectaba a todos y a cada uno de los ancianos órdenes prescriptivos. Sin embargo, la ley no era solamente expresión de un Derecho ya dado, ya formulado, ya constituido y ahora explicitado. Era una ley, si se quiere, más jurisdiccional en su proceso de formación y en su redacción final, que plenamente legal, si bien iría incorporando poco a poco elementos nuevos, genuinamente creadores, ya declarativos (pero de la novedad, no de lo anterior, aunque la novedad no sea más que un puro reflejo de lo antiguo, el modo de leerlo e interpretarlo por parte de hombres posteriores en el tiempo), bajo la forma de encaje en un cuerpo antiguo, por lo que su acción abrogatoria o derogatoria tampoco se hizo efectiva en toda su extensión y plenitud. Fue pausada, sumamente reposada, tanto su creación como su aplicación. La ley seguía compareciendo en un escenario plural donde el conflicto era la única forma de determinar exactamente la posición de cada célula normativa, nueva o antigua, y de ahí arrancaban derechos, posiciones, libertades y pretensiones. En todo caso, seguía prevaleciendo una idea de ley que quedaba indefensa y desvalida puesto que no se veía acompañada de instrumentos profilácticos, mecanismos dirigidos a asegurar su prevalencia y su uniforme interpretación, sino que, una vez creada, era la lanzada al mundo de los plurales operadores jurídicos que la manejaban con absoluta libertad para buscar con ella la Justicia, pero que no era depósito exclusivo de tal virtud, ni mucho menos ${ }^{154}$.

${ }^{154}$ Vid. C. Garriga, "Constitución política y orden jurídico en España: el efecto derogatorio de la Constitución de Cádiz", en M. Chust (coord.), Doceañismos, constituciones e independencias. La Constitución de 1812 y América. Madrid, 2006, pp. 33-77 (= ahora en C. Garriga y M. Lorente, Cádiz, 1812. La Constitución jurisdiccional, ed. cit., pp. 119-168); también, del mismo, "Continuidad y cambio del orden jurídico”, en C. Garriga (coord.), Historia y Constitución. Trayectos del constitucionalismo hispano. México, 2010, pp. 59-106; “Cabeza moderna, cuerpo gótico”, cit., pp. 115 ss.; y “¿La cuestión es saber quién manda? Historia política, historia del derecho y punto de vista”, en PolHis. Boletín Bibliográfico 
De esta forma, cuando se citan las Partidas y otros venerables cuerpos normativos (Concilios visigodos, Recopilaciones, Ordenamientos de Cortes, textos canónicos, Fuero Juzgo, Recopilación de Indias, documentos procedentes de otros reinos peninsulares, etc.), no se hace por simple placer erudito o por mera curiosidad histórica, sino como parte de la tradición jurídica subyacente que se va a modificar o que se va a intentar cambiar por parte de ese legislador gaditano, con un gran respeto y devoción, que muchas veces lleva a invalidar los propósitos primigenios de éste, a anularlos y a hacerlos inútiles de todo punto. Nada se crea; todo se reforma, se restituye al tiempo antiguo, se reordena con nuevos criterios que traen su causa de épocas anteriores. No es la nueva norma la que se impone a la anterior; la nueva norma vale en la medida en que sea conforme con lo antiguo, parámetro de la calidad del orden jurídico total. El Derecho viejo puede más y puede mejor que el Derecho nuevo. Sucede así por el predominio de esa idea de reformatio, de modificación o de restauración del antiguo Derecho como objetivo preeminente. Hay Derecho nuevo, pero supeditado a (puesto que es causado por) el anciano, que sólo se admite en tanto en cuanto se reconozca en lo anterior, en tanto en cuanto no desmerezca de la tradición de la que aspira a formar parte como una pieza más. El Derecho antiguo acaba por controlar el Derecho nuevo que ve limitadas sus posibilidades de acción al estrecho marco que le traza lo pretérito: le da el plácet para su inserción en la nueva, en apariencia (antigua, en el fondo), órbita del universo jurídico gaditano. No es el Derecho nuevo el que se crea de la nada y se impone sobre todo y sobre todos. El Derecho viejo es quien tiene en sus manos el patrón para convalidar todo aquello que se propone como nuevo. La Historia es así la verdadera legisladora, la que acoge en su seno lo que se aprueba y lo que ya había sido aprobado. Liberales y serviles usan este discurso de la misma manera porque sus intereses son los mismos: conservar lo ya existente, reforzarlo y hacerlo inmune al cambio. Un excelente ejemplo, claro y sintético, de todo lo que se viene diciendo lo tenemos en la cuestión sucesoria discutida en el seno de la Comisión de Constitución y luego convertida en los arts. 174 y siguientes del texto gaditano. Lo que se pretendía era cambiar el régimen sucesorio, aquella Ley Sálica en vigor desde la reforma de Felipe $\mathrm{V}$ en el año 1713, para lo cual el legislador gaditano no hace otra cosa que recuperar el orden previsto en las Partidas (P. 2, 15, 2), es decir, el legislador no idea un nuevo modelo sucesorio, sino que se contenta con recuperar el que había regido en España desde el siglo XIII hasta tiempos borbónicos, el convencional, el histórico, el fundamental, la costumbre antigua de España ${ }^{155}$. Evidentemente, en esta conducta

Electrónico del Proyecto Buenos Aires de Historia Política. Año 5, no 10 (segundo semestre de 2012). Dossier. Historia Politica e Historia del Derecho, pp. 89-100.

${ }^{155}$ Vid. Actas de la Comisión de Constitución (1811-1813). Estudio preliminar por Mª Cristina Diz-Lois. Coordinador: Federico Suárez. Madrid, 1976. Sesión de 18 de julio de 1811, p. 142. La cita a Partidas deviene aquí inexcusable, como en otros momentos. P. ej. Sesión de 13 de febrero de 1812, pp. 231-232; o Sesión de 26 de febrero de 1812, p. 240. A mayores, vid. F. Martínez Pérez (ed.), Constitución en Cortes. El debate constituyente 1811-1812. Madrid, 2011. Acta de la sesión secreta de 21 de febrero de 1812, p. 653 , recogiendo una intervención de Villagómez. 
normativa, no hay derogaciones ni abrogaciones, sino recuperaciones, restauraciones y revivificaciones del antiguo Derecho, del verdadero Derecho nacional originario. Cierto es que hay un acto decisorio, que las Cortes optan por ese concreto sistema hereditario, pero ese acto no crea ex nihilo un régimen nuevo, sino que supone explicitar la voluntad de las Cortes respecto de las varias propuestas o alternativas formuladas desde y por la Historia. Las Cortes no crean una nueva ley sucesoria; recuperan la anciana, la restituyen al lugar que la ha correspondido desde siempre, y eluden los tiempos intermedios, porque no pueden hacer otra cosa más que aceptar lo que el pasado les entrega. Operan condicionadas por toda una amplia gama de elementos previos a toda obra normativa. El pasado es el único constituyente auténtico. La Historia es la verdadera Constitución y la verdadera legisladora. De esta forma, se puede decir que no hay una total continuidad con el pasado, que éste no se reproduce cada vez en el presente, aunque sí se reinventa o regenera a partir de sí mismo y con sus propios mecanismos, pero no se advierte una marcada discontinuidad. No hay inmovilismo, si bien tampoco hay ruptura. Hay una dinámica jurídica controlada, dirigida, encauzada, perfectamente disciplinada, que hace que la apariencia de estaticidad se conserve durante mucho tiempo, hasta que ese Derecho nuevo empiece a actuar como genuino y real Derecho nuevo. Esto implicará un nuevo tiempo, una cesura, y la aparición de cambios en profundidad dentro del orden jurídico.

El sustento a todo esto lo proporcionaba un orden del Derecho, reflejo de un más general orden cósmico, que difícilmente encajaba o aceptaba la idea de derogar o de abrogar, es decir, la idea de comienzo y de terminación de cualquier norma, sino que confiaba en y a múltiples sistemas jurídicos, de dispar origen y evolución, yuxtapuestos y superpuestos, cada uno con sus propias fuentes de producción, que debían ser armonizados en cada caso concreto por jueces, magistrados y juristas de cara al hallazgo final de la Justicia. Toda norma, sin excepciones más que puntuales, existía desde su creación divina por siempre y al mismo tiempo que cualquier otra, era descubierta por los hombres y, a través de este procedimiento indagatorio, buscaba su participación práctica en la vida cotidiana, buscaba imponerse. Nada se desechaba, ni se eliminaba, sino que toda norma jurídica y su expresa formulación pasaban a formar parte del escenario común del Derecho. Debía determinarse su posición específica, formulada para cada caso singular que se sometía a resolución. No había, pues, reglas generales, sino que imperaba el universo del particularismo, del casuismo, tanto en las normas en sí mismas consideradas como en la ubicación de tales normas. Se trataba de un mundo que veía como coexistían piezas de diversa procedencia geográfica, jerárquica y, sobre todo, temporal, todas las cuales conformaban un patrimonio común en pleno vigor y con fuerza vinculante, sobre el cual se aplicaban unas nada claras reglas de conflicto (de geometría variable, elástica, maleable) que no tenían poder eliminador o depurador de la complejidad subyacente de un modo definitivo; simplemente las iban situando en modo casuístico y provisional en su lugar adecuado, dentro de un orden regido por la superior idea de consecución de la Justicia. 
El Derecho en cualquiera de sus versiones y elementos debía servir a esa finalidad última, la cual se imponía dictatorialmente por encima de cualquier otra consideración, ya prelaciones, ya vinculaciones, ya órdenes normativos estrictos. No existía ese rigor, ese monolitismo, esa intransigencia configuradora, sino que, al contrario, eran ordenamientos abiertos, dúctiles, adaptables, cambiantes en sus decisiones concretas bajo la apariencia de inmutabilidad, regidos por las exigencias de cada caso particular. Se pensaba y se actuaba jurídicamente de forma tópica, nunca sistemática. No se iba de lo general a lo particular, sino que el camino era el opuesto. Lo concreto específico, lo particular de cada caso debatido y sus circunstancias anexas determinaban la vida del Derecho. El fin era lo justo, lo equitativo de ese supuesto analizado, ya obtenido por vías jurídicas ordinarias, ya conseguido por vías que se situaban más allá de tales fronteras, pero que servían para reforzar, a modo de contrafuerte, la solidez de todo el orden mediante el recurso a valores, virtudes o principios alejados de la Justicia, los cuales, no obstante, contribuían a realizarla bajo determinados supuestos y condiciones, y a fundarla y a asentarla de un modo más sólido y firme (la gracia). Era, en suma, un mundo donde los monarcas legisladores ocupaban un puesto decisivo, en cuanto que ordenadores, garantes y cierres últimos del mismo, sin perjuicio del papel activo de la jurisprudencia, que era desarrollado precisamente al amparo, bajo la cobertura y de acuerdo con lo que el rey había sancionado de forma expresa o había tolerado en modo implícito. El arbitrio judicial era el corolario de este sistema: la libertad interpretativa para moverse en esa maraña normativa era un elemento indispensable de cara a la obtención del resultado justo que todos perseguían, una libertad que no era indiscriminada, ni absoluta o total, sino que estaba dirigida por reglas específicas y estaba orientada al fin último, que era la Justicia del caso concreto, como ya se ha expuesto. Solamente esa flexibilidad en el manejo y en la interpretación de las fuentes podía evitar el caos. Estos rudimentos funcionaban con regularidad en toda Europa en esa larga era del Derecho Común que se prolongó hasta comienzos del siglo XIX. España no era una excepción a este mundo eterno del Derecho, a este mundo sin tiempo donde cada norma valía por siempre, sin discusión, a este mundo de planos normativos superpuestos e integrados, a la espera de su eventual posibilidad aplicativa dependiente del caso particular en el que se viesen involucrados. Era un orden que precisaba de la interpretación, que no se leía solo per se, sino que requería de intermediaciones indispensables, de ojos que leyesen, bocas que dijesen y manos que escribiesen, todos ellos formados y cualificados. Esta triple y erudita exigencia (visual, lectora y escritora) daba al jurista un papel clave, como constructor, asesor y aplicador de todo el Derecho final resultante, pero un jurista erudito, sabio y prudente, que debía conocer los márgenes del Derecho y también los de aquellas otras disciplinas que daban forma a ese conjunto prescriptivo global por medio del cual se ordenaba, se disponía, se prohibía o se autorizaba sin necesidad de recurrir, siempre y en todo lugar, al Derecho. Orden, en fin, de probabilidades y de variables continuadas, de incertidumbres y de oscuridades, laberíntico y oscuro, sin vinculación a otros ide- 
ales más que a los de la Aequitas o la Iustitia, como máxima aspiración de todo operador jurídico, comenzando por aquellos reyes que seguían siendo reputados vicarios de Dios en la tierra ${ }^{156}$.

Si no hay pasado, ni presente jurídicamente hablando, si todo el Derecho es y está al mismo tiempo, con independencia de la época de su gestación, si no se derogan piezas de este mosaico complejo, sino que se prefieren o se superponen en algunos casos unas a otras, sin que esto llegue a conformar reglas generales o pautas universales de actuación, si nada se tira o se pierde en ese mundo jurídico, puesto que todo forma parte del mismo orden prescriptivo y acumulativo, de tipo tradicional y sedimentario (compuesto de varios elementos, ligados a una visión teológica del mundo que nunca llega a desaparecer), orden plural, con muchos componentes implicados, de textura abierta e incierta, sometido al cálculo de probabilidades aplicativas que determinan los juristas, los jueces o los reyes, si este orden descrito, como ya se ha dicho, es el dominante en España en el Antiguo Régimen, no podemos, ni debemos bajo ningún concepto, contemplar la labor iniciada en 1810 con una óptica positivista, legalista y estatalista, que no existía ni por asomo. Si tenemos todo esto en cuenta (sobre todo, la falta de aislamiento entre pasado y presente, sino, antes bien, su coexistencia más o menos pacífica, la perduración de todo el orden jurídico y su recuperación por medio de la mejora o corrección del mismo, en una suerte de eterno-retorno jurídico), la visión de la Constitución de 1812 y de la obra legislativa gaditana ha de cambiar de forma clara y notoria. ¿En qué sentido? No es un Constitución o una legislación nueva la que allí se presenta, o no lo es de un modo absoluto y completo. Es una Constitución antigua, histórica, tradicional, de raíces consuetudinarias en última instancia, construida con retales del pasado, con dispositivos e instituciones tomados del mundo pretérito que parecía disolverse, una Constitución que carece de cláusula derogatoria porque no estaba en condiciones de (ni tenía el poder suficiente para) cancelar el caudal histórico que la nutría y la definía. Lo que se hace en la Constitución y en la legislación ordinaria es afirmar instituciones y leyes antiguas, recuperarlas, fortalecerlas, y asegurar la aplicación del modelo monárquico y católico que venía existiendo en España desde tiempos medievales, dándoles a todas ellas una nueva sistemática que facilite su reconocimiento y evite su posible ocultación o ambigüedad de cara al inmediato futuro. Se toma el pasado, se busca un modelo pretérito operativo y se limpia de impurezas, al mismo tiempo que se dota a la vida pública de los instrumentos precisos que impidan cualquier deriva despótica y se le da un orden que permita su clarificación. El pasado no sólo es fuente de poder y de institutos; es modelo de lo que se tiene que hacer para eludir los peligros de la degeneración que se había dado en tiempos modernos. Por eso, el pasado es útil al estilo ilustrado: por-

\footnotetext{
${ }^{156}$ Para todo lo anterior y con las precisiones y matices indicados, vid. A. M. Hespanha, Cultura jurídica europea. Síntesis de un milenio. Edición al cuidado de Antonio Serrano González. Traducción de Isabel Soler y Concepción Valera. Madrid, 2002, pp. 58 ss.
} 
que es fuente donde se encuentra todo lo que debe existir, y, al mismo tiempo, es enseñanza que previene frente a posibles desvíos. Las piezas varias que integran Cádiz no son invención de las Cortes, ni de sus diputados; son creación de la Historia, son piezas más o menos identificadas en el pasado y con el pasado, lo que conduce a Dios como depositario último de todas las esencias constitucionales y legales primarias, como creador del marco político-jurídico al que ahora sus criaturas están dando un nuevo orden. Recuérdese la primera invocación del texto constitucional.

Pero esta descripción relatada no implica parálisis permanente o estaticidad absoluta. El orden jurídico del que se formaba parte no era algo monolítico, intocable, inmodificable e inmanejable. El Derecho del Antiguo Régimen procedía a evolucionar también, a avanzar, no obstante su origen divino, esto es, su perfección ínsita y esencial, a través de mecanismos internos humanos de auto- o de regeneración, a partir de sus propios elementos consustanciales, que implicaban la suma, la adición, nunca la resta o la desaparición (salvo casos excepcionalmente justificados por causa de pública utilidad o de necesidad) de elementos jurídicos para que se imbricasen en el complejo orden coral ya construido. Todo estaba creado. Restaba al hombre simplemente el descubrimiento de ese Derecho, la mejora de esa creación divina o la corrección o enmienda de las impurezas que la actividad humana hubiera podido introducir en el plan de Dios. Así se efectúa en el proceso que conduce a Cádiz: de lo antiguo se pasa a lo antiguo mínimamente reformado, enmendado, corregido o mejorado, que aparenta ser nuevo, sin llegar a serlo en su totalidad. Lo pasado se somete a un proceso de recomposición y de presentización, es decir, de conversión en realidad presente, y también viceversa. Nada se pierde en el camino; nada se omite; nada se destruye o se desecha; nada se cambia en lo primordial. Todo permanece bajo otras palabras, bajo otras rúbricas o en otras sedes. Se refuerza, en todo caso, su existencia para, de esta forma, asegurar una persistencia que permita cumplir con el espíritu de los nuevos tiempos y evitar las derivas tiránicas de épocas anteriores. Y así se hace ciertamente. Recuperar y garantizar la pervivencia de lo recuperado. El pasado invade, pues, el presente de un modo indiscutible, y se ve asegurado por el mismo ${ }^{157}$.

De nuevo y de modo inapelable, todo esto nos conduce a Alfonso X como dual lugar común ya conocido, como tópico político y como tópico jurídico, a la par, inescindible, aunque sobre ambos comienzan a fraguarse diferenciaciones que no son invento gaditano, sino de anterior procedencia. Alejada de todo punto del modelo político, ya abierta y duramente cuestionada por los ilustrados, pero no recorrida por los diputados gaditanos como se podrá ver, la obra alfonsina aparece, pues, en una dimensión doble, como ejemplo invocado y como norma presta a ser revisada, dentro de este contexto parlamentario iniciado en septiembre de 1810. Es ya algo más que un sencillo apólogo, es algo más que un simple ejemplo de literatura didáctica, enciclopédica, didascálica; ahora se presenta como un texto vivo sobre el que se puede

${ }^{157}$ Nuevamente, remito a mi "Repensar la Constitución de 1812", cit., passim. 
eventualmente actuar: algunas de sus partes son Leyes Fundamentales, fracciones de la vieja Constitución, y otras simplemente Leyes Positivas, llanas, sin motivos aparentes para destacar, sin mayor trascendencia. Las primeras son constitucionales en origen, en denominación y en efectos; las segundas no alcanzan tal condición y se mueven en un plano vicario, subordinadas a las primeras, discretamente asentadas en un edificio al que adornan, pero no sustentan. Mientras que aquéllas, las primeras, las basilares, no pueden ser cuestionadas, ni amenazadas por impulsos reformistas, éstas, las positivas, las contingentes, conformarán el espacio propio sobre el cual las Cortes gaditanas despliegan sus fuerzas innovadoras ${ }^{158}$.

5. Comenzaré por los momentos del debate constitucional en el que se ven afectadas la primera clase de leyes apuntadas. Desde el instante mismo en que se inicia la discusión de este signo, a finales del mes de agosto de 1811, se habla de un proyecto

${ }^{158}$ Para la distinción apuntada, cfr. supra en Parte Primera, nota $\mathrm{n}^{\mathrm{0}} 74$, y la intervención del diputado Aner, en Constitución en Cortes, ed. cit. Sesión de 18 de enero de 1812, pp. 1.005-1.006: "De nada servirán los desvelos y afanes de V. M. en restablecer la sábia, respetable y antigua constitución de la monarquía española, si al mismo tiempo no adoptase $\mathrm{V}$. M. todas las medidas convenientes para su estabilidad y observancia (...) La constitución, Señor, es la ley que por su naturaleza debe llamarse estable, es el área donde se asienta y reposa el grande edificio de la sociedad; es la tabla donde cada ciudadano lee los derechos que le corresponden y las obligaciones á que está sujeto; es en suma la gran carta en que la nación establece su Gobierno, declara su religión, y asegura sus imprescriptibles derechos. No tratemos, Señor como algunos han persuadido, de formar una nueva constitución, ó hacer un nuevo pacto social; tratemos, sí, únicamente de restablecer nuestras leyes fundamentales, cuyo olvido ha acarreado á la nación tantas desgracias, porque la nación española no ha dexado de ser nación; á pesar de la actual insurrección ha conservado sus leyes, ha tenido Gobierno, y los individuos que componen la nación se han conservado en sociedad y en unión para resistir al poder y á las maquinaciones de Bonaparte. Las leyes fundamentales, que compiladas en un código restablecemos á su observancia, por su naturaleza ó importancia deben ser estables (...) Entre las leyes constitucionales unas deben llamarse perpetuamente estables, quales son las que determinan los derechos de los ciudadanos, su religión, la forma de gobierno, etc. Otras menos estables, como son las que determinan las calidades que deban tener los diputados en Córtes, el modo de hacer las elecciones, que las Córtes se celebran anualmente, etc. etc.”. Cfr. DSCGE. Tomo IV, n ${ }^{\circ}$ 472, pp. 2.651-2.653. La distinción la anticipan Argüelles, en Constitución en Cortes, ed. cit. Sesión de 2 de septiembre de 1811, p. 94 (Cfr. DSCGE. Tomo III, nº 335, p. 1.742), contraponiendo fundamentales y positivas, e Inguanzo, en Constitución en Cortes, ed. cit. Sesión de 30 de septiembre de 1811, pp. 383-385 (Cfr. DSCGE. Tomo III, nº 363, pp. 1.959-1.960). La hacen suya posteriormente Borrull, en Constitución en Cortes, ed. cit. Sesión del día 20 de enero de 1812, pp. 1.035-1.036, diferenciando entre leyes fundamentales y otras que son necesarias para ejecutar las anteriores, o sea, los medios para llevarlas a efecto; Oliveros, en Sesión de 22 de enero de 1812, pp. 1.042, distinguiendo entre leyes constitucionales y leyes positivas; y Muñoz Torrero, en Sesión de 30 de septiembre de 1811, p. 386, y en Sesión de 22 de enero de 1812, p. 1.046, quien habla de leyes fundamentales y leyes comunes. Cfr. DSCGE. Tomo IV, $\mathrm{n}^{\circ} 474$, pp. 2.670-2.671; $\mathrm{n}^{\circ} 475$, p. 2.675; Tomo III, $\mathrm{n}^{\circ}$ 363 , pp. 1.960-1.961; y Tomo IV, $\mathrm{n}^{\circ} 476$, p. 2.680. Ecos de esta distinción se hallan en debates posteriores. Cfr. la intervención de los diputados Cepero, Echevarría y Caro, ya en tiempos de legislatura ordinaria, en Córtes. Actas de las Sesiones de la Legislatura Ordinaria de 1813. Dieron principio el $1^{\circ}$. de Octubre de 1813 y terminaron el 19 de Febrero de 1814. Madrid, 1876. Sesión de 28 de octubre de $1813, n^{\circ} 29$, pp. 167-168. 
formado para el arreglo y mejora de la constitución política de la nación española, dado que estaba reservado en exclusiva a los españoles, representados por esas Cortes, mejorar y arreglar su constitución $n^{159}$. El preámbulo del proyecto, después convertido en el ya citado preámbulo de la Constitución, incide en esta dirección: providencias y precauciones son lo que se adoptan para asegurar de una vez para siempre las antiguas Leyes Fundamentales a fin de garantizar su respeto y su cumplimiento. Ésa es la idea principal de todo ese proceso. A eso se reduce la Constitución y eso es, en fin, la Constitución de Cádiz: un catálogo ordenado, sistemático, mejorado, de las viejas Leyes Fundamentales, modificadas o aseguradas por medio de vías e instrumentos que garanticen su aplicación.

Con esto se explica todo lo demás pues los conceptos políticos y jurídicos derivan de esa primera afirmación contundente, de esa Historia realmente constituyente y constitucional, como muestra en larga intervención el diputado García Herreros, con cita a algunas de esas Leyes Fundamentales que se han de respetar, tales como P. 2, 15, 5 (prohibición para los reyes de partir, dividir o enajenar los bienes de la Corona), P. 3, 11, 29 (sobre el valor del juramento del rey hecho en daño o menoscabo del reino), o P. 2, 1, 10 (sobre el tirano, es decir, el rey que usa mal de su poderío), en un debate acerca de la validez de los tratados concertados por Fernando VII y en clara defensa de los intereses de la Nación ${ }^{160}$. Sobre este primer inciso, comenzarán los de-

${ }^{159}$ Son las palabras con las que el presidente de las Cortes inaugura la Sesión de 25 de agosto de 1811, en Constitución en Cortes, ed. cit., p. 21. Cfr. asimismo DSCGE. Tomo III, nº 327, pp. 1.683-1.691, para la sesión completa.

${ }^{160}$ Cfr. DSCGE. Tomo I, no 95 . Sesión de 30 de diciembre de 1810, pp. 263-265, en donde se habla de los "incontestables derechos y autoridad que la Nación tiene sobre la persona y acciones de sus Monarcas", esto es, la "Constitución de Estado, ó sean leyes fundamentales, en que determinó la forma y cualidades de su gobierno", donde se contienen el pacto social que precedió a su creación y las condiciones con que se depositaban en el príncipe los derechos naturales: "En ellas se deslindan con escrupulosidad los derechos de los Príncipes, se les prescriben sus derechos naturales y se ponen límites bien estrechos al ejercicio de la potestad soberana, de modo que no pudiese degenerar hacia la arbitrariedad y despotismo. Sus decretos se obedecían, pero no tenían fuerza de leyes hasta que eran aprobados por las Córtes". Ahí estaban, pues, los límites al poder de los reyes y la necesaria colaboración-limitación-control por parte de las Cortes, expresión de esa Nación, de donde se seguían ciertas restricciones indisponibles para los monarcas: enajenar los bienes de la Corona, privar a los súbditos de sus propiedades, resolver por sí solos los asuntos graves atinentes al interés y prosperidad generales, etc. Y añadía: "No es mi ánimo referir ahora todas las leyes fundamentales de la antigua Monarquía española; bastan las indicaciones que he hecho para conocer las bases y espíritu de su legislación é integridad política desde aquélla época, y para persuadirse que desde entonces las leyes constitucionales restringieron de tal modo el ejercicio de la potestad soberana, que la Nación no podía ligarse al cumplimiento de una obligación que ella misma no se hubiese impuesto. Sus Príncipes gobernaban bajo el imperio de la ley: eran inferiores á ella, y su soberanía jamás fue tan absoluta que por sí pudiese alterar, variar y mucho menos derogar las leyes fundamentales". Una Constitución así, con leyes tan justas y sabias, no podía más que proporcionar el florecimiento de la Nación, elevar su grandeza y poder, y colocarla en una posición de primacía. La tiranía subsecuente, con Witiza y Rodrigo, provocó la ruina de todo esto y una guerra inevitable, situación análoga a la que se está viviendo en 1810. En consecuencia, pide, como en la primera Edad Me- 
bates en donde se realizan invocaciones a los textos jurídicos de nuestra Historia, en ese momento vigentes, los códigos de la nación, a los Concilios de Toledo, o a ciertas imprecaciones religiosas con su correspondiente apoyatura normativa, dado el conglomerado teológico-jurídico que servía de sustento a todo este orden tradicional. Se cita así como pilar del Estado y de la Monarquía la santa fe católica y se recuerda, al modo que lo hace Güereña, como Fuero Juzgo y Fuero Real, «el sabio código de las Partidas», las dos Recopilaciones castellanas y la de Indias, trataban con sumo esmero a la religión, la preconizaban y recomendaban todas sus máximas. Simón López detecta insuficiencias teológicas en el arranque del proyecto constitucional, a diferencia de lo que prevenía una ley de Partida, y echa en falta que no se mencione a Jesucristo, como redentor y establecedor de la religión católica, apostólica, romana, y como tal se debia hacer mención de él y de la purísima virgen María. Para Borrull, el concepto de Nación que se maneja está tomado de P. 2, 10, 1, en el sentido de pueblo como ayuntamiento de todos los homes ${ }^{161}$. En esos primeros compases, la conocida intervención del diputado Gómez Fernández, solicitando se indicasen cuáles eran esas Leyes Fundamentales que se iban a mejorar para poder clarificar así el panorama constitucional y saber qué se estaba haciendo, pone como ejemplo de aquéllas a las Partidas y a las incluidas en las Recopilaciones, es decir, identifica algunos de los depósitos donde se pueden hallar aquellos materiales constitucionales sobre los que se tiene que trabajar para ser repuestos o reparados ${ }^{162}$. Es conocida la réplica de Calatrava, donde aparece una expresión muy exacta de ese tránsito o compromiso entre

dia, que "restablezcamos, pues, como nuestros mayores las Monarquías, las leyes con que la fundaron subsisten aún, á pesar de las trasgresiones y atentados del despotismo; uno mismo es su espíritu: la Monarquía no es absoluta, como no lo había sido antes; en las leyes con que la fundaron se restringe el ejercicio del poder soberano á límites muy estrechos, según que la experiencia les había hecho conocer que convenía para evitar los males que acarrea el despotismo".

${ }^{161}$ Cfr. Constitución en Cortes, ed. cit. Sesión de 25 de agosto de 1811, pp. 23-24 (Güereña); pp. 24-25 (Simón López); y p. 28 (Borrull).

${ }^{162}$ Cfr. Constitución en Cortes, ed. cit. Sesión de 25 de agosto de 1811, p. 35-36: "Señor, la razón natural dicta, y la experiencia nos enseña todos los días, que siempre que se trata de restablecer alguna cosa que no estaba en uso, ó de añadirla algo que no tenía, se dé ó exponga la razón ó conveniencia que trae ponerlo en uso, ó qué razón ó conveniencia puede haber para que se mejore. Esto que ocurre en qualquier caso, y á qualquiera gente es más importante quando se trata de las leyes; y no así como quiera, sino de las leyes fundamentales del reyno, así de Partida como recopiladas. Todas los autores de unas y otras están conformes, que siempre que se trata de restablecer una ley que no estaba en uso, ó hay que mudarla, se haya de saber por que no estaba en uso; si trae conveniencia ú perjuicio, y si el restablecerla ó mudarla trae las utilidades que se propone. De aquí nace lo que voy á pedir para todos y para cada uno de los artículos de la constitución; á saber: que la comisión ó uno de sus individuos, en cada artículo que se trate nos diga: lo dispuesto en este artículo no estaba en uso, pero estaba mandado en la ley A, ó en la ley B. Este no estar en uso dimanaba de este abuso ó arbitrariedad, y trae (...) Iba á decir lo que hallo que debe hacerse en esto, y no solo yo, sino la comisión lo dice ó V. M. (...) Con que ahora la comisión lo ha juzgado necesario; y por no haberlo hecho no la culpo, porque bien sé que sería obra de romanos; pero debe hacerlo aquí ántes de principiar la discusión de qualquiera artículo. Así sabrá V. M. por que no estaban en uso las leyes que se reformen, y por que se añaden ó mudan las que estaban faltas". 
pasado y presente, tan peculiar del momento gaditano: las Cortes no son un colegio de abogados y no han de desmenuzar cuáles Leyes Fundamentales se tocan, mejoran o alteran, sino que son un cuerpo constituyente, paradójica unión de un sustantivo tradicional y de una adjetivo revolucionario, de todo punto incompatibles. No es de extrañar que Calatrava diga esto, teniendo conciencia como se tenía, de que la Constitución no estaba radicada en un lugar concreto y exclusivo, en un único texto escrito, sino dispersa en muchos cuerpos, ya legales, ya consuetudinarios, ora escritos, ora no escritos, de dispar procedencia temporal y geográfica, pero de los que todo el mundo tenia noticia o, cuando menos, conciencia aproximada. La Constitución era algo que se sentía o intuía, más que algo que se conocía o reconocía, algo que se percibía por otros medios y vías diferentes a las exclusivamente jurídicas, puesto que era un orden que lo regía todo y en el que todos, autoridades y particulares, en mayor o menor medida, estaban involucrados, esto es, representados y dirigidos ${ }^{163}$.

Dado aquel propósito restaurador de las Cortes gaditanas, en momentos sucesivos van siendo destiladas, decantadas, y así conocidas y explicitadas, con cuentagotas, algunas de esas Leyes Fundamentales, como sucede con la religión católica, las propias Cortes y su regular funcionamiento, o el credo monárquico moderado, valladares que no pueden ser sorteados por ningún poder político, ni jurídico, cualesquiera que sea la forma que adopte en el seno de las Cortes actuantes, materias indisponibles e intocables puesto que son pilares de la realidad política primaria. Y para localizarlas se habla del pasado visigodo, de los tiempos medievales, de los textos alfonsinos, de las Cortes y de sus ordenamientos o de las Recopilaciones, muchas veces sin cita precisa, exacta e inequívoca, pero con conciencia y conocimiento del contenido, al menos de forma aproximada. Los testimonios de Llaneras ${ }^{164}$, Aner ${ }^{165}$, o Terrero ${ }^{166}$, surgidos al debatirse los artículos 2 y 3 de la futura Constitución, dan paso a la poderosa opinión de un ambiguo liberal como era Agustín de Argüelles, quien postulará que la Comisión ha excluido explícitamente toda forma de gobierno que no sea la monár-

${ }^{163}$ Cfr. Constitución en Cortes, ed. cit. Sesión de 25 de agosto de 1811, p. 36 (Calatrava).

${ }^{164}$ Cfr. Constitución en Cortes, ed. cit. Sesión de 28 de agosto de 1811, pp. 38-39 (Llaneras). Cfr. además DSCGE. Tomo III, $\mathrm{n}^{\circ} 330$, pp. 1.705-1.716, para la sesión completa. Reiteran esa consideración de la religión como Ley Fundamental, por ejemplo, Muñoz Torrero, en la sesión de 31 de agosto de 1811 (así, en Constitución en Cortes, ed. cit., p. 87; y en DSCGE. Tomo III, $\mathrm{n}^{\circ} 333$, p. 1.735), o Inguanzo, en la de 2 de septiembre del mismo año (en Constitución en Cortes, ed. cit., p. 103; y en DSCGE. Tomo III, $\mathrm{n}^{\mathrm{o}} 335$, p. 1.745). Villanueva, por su parte, añade la "monarquía moderada y la unidad de la religión católica", en Constitución en Cortes, ed. cit. Sesión del día 23 de enero de 1812, p. 1.046; y en DSCGE. Tomo IV, n 476 , p. 2.680.

${ }^{165}$ Cfr. Constitución en Cortes, ed. cit. Sesión de 28 de agosto de 1811, pp. 40-41 (Aner).

${ }^{166}$ Éste, en cambio, desde un prisma más liberal. Cfr. Constitución en Cortes, ed. cit. Sesión de 28 de agosto de 1811, pp. 41-43 (Terrero): "Todo cabe en la clase de humano, y en ella no está exênto el monarca. Sepan, pues, las cabezas coronadas que en un fatal extremo, en un evento extraordinario, no fácil, mas sí posible, la nación reunida podría derogarle su derecho. Esto tenía que decir, y dixe”. Algo en lo que insiste el Conde de Toreno, en famosa y citada intervención, en pp. 56-59: "Y no porque la nación no pueda ni deba; la nación puede y debe todo lo que quiere". 
quica, dado que nunca se olvidó que las Cortes estaban congregadas para restablecer la primitiva constitución, mejorándola en todo lo que conviniese; asi es que sabía que habían venido no tanto á formar de nuevo el pacto, como á explicarle é ilustrarle con mejoras ${ }^{167}$. Borrull vuelve, por su parte, a la típica argumentación absolutista: el Estado se halla constituido desde tiempo inmemorial y la Monarquía moderada está al frente del mismo, sin que quepa discutir otra forma diferente ${ }^{168}$. Para Llamas, sin embargo, está claro que las antiguas leyes constitucionales legitimamente establecidas y practicadas por la nación, no pueden las Cortes derogarlas ó alterarlas, á menos que la necesidad no sea tan urgente, como fue la que dio lugar al establecimiento de los gobiernos y principio al derecho social, lo que no impide que se forme con ardor y esmero el mejor plan de Constitución posible ${ }^{169}$. Las discusiones, a propósito de ese artículo 3, el de la soberanía nacional, siguen los mismos derroteros en reuniones sucesivas con dos frentes perfectamente trazados ${ }^{170}$. Villagómez, por ejem-

${ }^{167}$ Cfr. Constitución en Cortes, ed. cit. Sesión de 28 de agosto de 1811, pp. 43-45 (Argüelles).

${ }^{168}$ Cfr. Constitución en Cortes, ed. cit. Sesión de 28 de agosto de 1811, pp. 47-50 (Borrull). Ni siquiera podría modificar las Leyes Fundamentales, impugnando en su totalidad el artículo 3 susodicho. Sigue su argumentación el obispo de Calahorra, en pp. 50-54, con reivindicación de la soberanía regia, si bien matizada o moderada por el juego de las Leyes Fundamentales: "En suma el pueblo español trasladaba al rey que elegía toda la soberanía; pero le ponían freno las leyes fundamentales que juraba, para que, aunque enteramente autorizado, no pudiese partir, dividir, ni enagenar los bienes pertenecientes á la corona: aunque independiente, procurase mas bien el beneficio de la patria que el suyo propio, y aunque legislador supremo, no pudiese dar fuerza, vigor ni perpetuidad de ley á sus órdenes y decretos, sino quando lograban el consentimiento de las Córtes, que compuestas de las tres clases representaban la nación (...) La que se supone, ó se quiere suponer, residir en la nación, ya la enagenó ó trasladó á sus reyes electivos y después á los hereditarios, pues como se ha demostrado, y lo acreditan las leyes de nuestros códigos, los reyes de España han sido siempre sin interrupción soberanos, supremos legisladores, etc. La nación entonces no era soberana, sino el rey, porque es al parecer una cosa disonante que la nación dé á su rey toda la soberanía para que la dirija, conserve y defienda, y se quede con toda ella para dirigirse, gobernarse, conservarse y protegerse; que haciendo á su rey cabeza de la nación, la nación sea cuerpo y cabeza de sí misma, y haya dos cabezas en un solo cuerpo; y si en el reyno el pueblo es sobre el rey, el Gobierno del reyno es popular, no monárquico. De aquí se sigue que trasladada por la nación la soberanía a su monarca elegido, queda este constituido soberano de su nación, y nadie le puede despojar del derecho de la soberanía; mas debe observar fielmente las condiciones y pactos que le están impuestos por leyes fundamentales del reyno, y quando faltare á ellos tiene derecho la nación á exigir su cumplimiento, obligando el rey a la puntual observancia de la constitución por los medios que tenga prescritos la ley".

${ }^{169}$ Cfr. Constitución en Cortes, ed. cit. Sesión de 28 de agosto de 1811, pp. 55-56 (Llamas).

${ }^{170}$ Cfr. Constitución en Cortes, ed. cit. Sesión de 29 de agosto de 1811, pp. 59-62. Juan Nicasio Gallego defiende la soberanía nacional puesto que "si ántes de constituirse la nación fue soberana esencialmente, lo es en el día, y lo será siempre, aun quando haya pasado por una, dos ó diez constituciones. Una nación, ántes de establecer sus leyes constitucionales, y adoptar una forma de gobierno, es ya una nación, es decir una asociación de hombres libres que se han convenido voluntariamente en componer un cuerpo moral, el qual ha de regirse por leyes que sean el resultado de la voluntad de los individuos que lo forman, y cuyo único objeto es el bien y la utilidad de toda la sociedad. Esta nación por las leyes constitucionales que luego establece, contrae ciertas obligaciones consigo misma; pero como voluntariamente las contrae, y el objeto de ellas es la felicidad general de sus individuos, puede derogarlas ó reformarlas 
plo, habla de la contradicción entre lo que proclama el preámbulo de la Constitución proyectada y ciertos pasajes de las Partidas (concretamente, P. 1, 1, 5, P. 2, 1, 1 y P. 2, 1, 12, acerca del poder de hacer leyes), a salvo siempre el espíritu de la libertad política y civil que se desprende de Fuero Juzgo, Partidas, Fuero Viejo, Fuero Real, Ordenamiento de Alcalá, Ordenamiento Real y Nueva Recopilación, el cual debe ser armonizado con el convencimiento manifestado por el texto constitucional y con la autoridad de aquellas Leyes Fundamentales ${ }^{171}$. Se llega así a una abierta proclamación conclusiva, a modo de recapitulación de todo lo expuesto, en la boca de Muñoz Torrero, no sospechoso de ínfulas absolutistas, en la dirección expresada por los diputados anteriores:

"La comisión, para exponer estas máximas conocidas y observadas por nuestros mayores, ha seguido religiosamente el espíritu de las antiguas constituciones de los diferentes reynos ó provincias que componen la península, á fin

desde el momento en que vea que se oponen á dicha felicidad, que es el único fin de su formación"; pp. 63-65. Villagómez, por el contrario, expone: "Las resoluciones y medidas para salvar la patria, para restituir al trono á nuestro deseado monarca, y para restablecer y mejorar una constitución que sea digna de la nación española, objetos de la reunión de este augusto Congreso; estos grandes objetos, que son los únicos que deben atenderse, estaban desempeñados y cumplidas dignamente las sagradas y difíciles obligaciones de sus diputados, si posponiendo todo interés particular de los individuos general de la patria se ordenan estos puntos capitales de la constitución en el breve, claro y sencillo texto de ley constitutiva de la monarquía, y esto no puede ser otro que el ya decretado en el artículo 2 (...) No caben más oportunas providencias y precauciones que aseguren de un modo estable y permanente el entero cumplimiento de las antiguas leyes fundamentales de esta monarquía"; pp. 67-69. Lera sostiene, por su parte, que las Leyes Fundamentales que integran la Constitución son las condiciones del pacto social por el que se instituye una Monarquía y están en la Historia por lo que hay que acudir "á las determinaciones de las Córtes que se conservan, á los usos y estilos inmemoriales de la nación, y á los códigos y leyes de ella. De estos monumentos hemos de sacar é inquirir las condiciones y limitaciones con que trasladó el uso de la soberanía á los monarcas. Todo lo que estos hayan executado contra los pactos y limitaciones con que se les concedió este poder, lo han hecho sin autoridad y por mero abuso, y por consiguiente no debe subsistir; porque así como pudo la nación no adoptar el gobierno monárquico quando se constituyó, pudo también poner al monarca ciertas y determinadas condiciones y limitaciones que no pudiese traspasar, siendo nulo y de ningún valor lo que se executare contra ellas. En efecto, nos consta por la historia por los códigos legales las limitaciones impuestas á nuestros monarcas en el uso de la soberanía; ellos nunca han podido imponer tributos ni hacer otras leyes sin el consentimiento de la nación; estas condiciones y limitaciones se le pudieron imponer y se le impusieron al monarca por la nación en virtud de la soberanía que residía en ella al constituirse, y cuyo uso ó exercicio le trasladó baxo dichas limitaciones"; y pp. 69-74. Inguanzo, en una línea abiertamente absolutista, habla sin tapujos de "nuestra antigua excelente constitución" que ha de ser asegurada para contener los abusos del poder, los excesos de la arbitrariedad, "y que la administración pública vaya siempre enderezada por el camino de la justicia y bien de la patria". Precisamente el respeto al rey legítimo, a la Constitución, leyes y religión tradicionales, es lo que ha permitido conservar la unidad y el ser de la Nación, "el nudo que volvió á atar la cadena del estado que se había roto", fuera del cual sólo eran imaginables el caos, los excesos y el laberinto irresoluble. Cfr. además DSCGE. Tomo III, nº 331, pp. 1.717-1.726.

${ }^{171}$ Cfr. Constitución en Cortes, ed. cit. Sesión de 29 de agosto de 1811, pp. 63-64 (Villagómez); y DSCGE. Tomo III, n 331, pp. 1.719-1.720, con nueva invocación a P. 2, 1, 1. 
de manifestarlos á todos y dar á la nación entera una misma ley fundamental (...) Sólo hemos tratado de restablecer las antiguas leyes fundamentales de la monarquía, y declarar que la nación tiene derecho para renovarlas y hacerlas observar; tomando al mismo tiempo aquellas oportunas providencias y precauciones que aseguren de un modo estable y permanente su entero cumplimiento para que no volvamos á caer en los pasados desórdenes"172.

El tópico de las Leyes Fundamentales que componen una Constitución o que se recomponen para alumbrar un texto nuevo cala hondo. Es de presencia constante y recurrente por todas las facciones políticas inmersas en el debate constitucional, lo que demuestra un convencimiento en su empleo y en el sentido exacto que se le da al mismo. Lo acreditan sucesivas invocaciones puestas de relieve al tratar cada uno los preceptos constitucionales a medida que se avanza en el debate sobre el proyecto. La potencialidad del mismo la ponen de manifiesto, tanto liberales como absolutistas, a modo de lugar de encuentro del que parten sus respectivas posiciones ideológicas. Los primeros ven las Leyes Fundamentales que integran la Constitución como un elemento a superar, como una plataforma desde la cual se puede iniciar la construcción de todo un nuevo proyecto de futuro. Es el punto de arranque de la nueva Constitución, que puede servir en parte, pero que debe ceder ante el impulso de la Nación y de conformidad con lo que decida esa Nación de poder absoluto y omnímodo ${ }^{173}$.

${ }^{172}$ Cfr. Constitución en Cortes, ed. cit., p. 75 (Muñoz Torrero). Itera esa necesidad de unificación en sesión de 2 de septiembre de 1811: "En la constitución actual deben refundirse todas las leyes fundamentales de las demás provincias de la monarquía., especialmente quando en ella ninguna pierde", en Constitución en Cortes, ed. cit. Sesión de 2 de septiembre de 1811, p. 101; y DSCGE. Tomo III, n 335 , p. 1.745. Y, como colofón explícito, cfr. Constitución en Cortes, ed. cit. Sesión de 17 de enero de 1812, pp. 1.002-1.005; y DSCGE. Tomo IV, n 471, pp. 2.648-2.649, citado infra.

${ }^{173}$ Cfr. Constitución en Cortes, ed. cit. Sesión de 28 de septiembre de 1811, pp. 363-366, con intervenciones sucesivas de Terrero, Argüelles, Aner y el Conde de Toreno; Sesión de 7 de octubre de 1811, pp. 456-457 (Conde de Toreno); Sesión del día 15 de noviembre de 1811, pp. 689-670 (Gallego); Sesión de 17 de enero de 1812, pp. 992-993 (Argüelles); pp. 993-996 (Conde de Toreno y Leyva); y p. 997 (Caneja); y Sesión de 22 de enero de 1812, p. 1.044 (Gallego). Cfr., respectivamente, DSCGE. Tomo III, $\mathrm{n}^{\circ}$ 361, pp. 1.946-1.948; nº 370, pp. 2.009-2.010; y p. 2.263; y DSCGE. Tomo IV, n ${ }^{\circ} 471$, pp. 2.643-2.646; $\mathrm{y} \mathrm{n}^{\circ} 475$, p. 2.676. Anteriormente, en relación al proyecto de ley sobre incorporación de señoríos, una de las piezas clave para asegurar la soberanía y apuntalar a la Nación, las reflexiones de algunos diputados caminaban por esta misma dirección. Cfr. DSCGE, Tomo II, $\mathrm{n}^{\circ} 252$. Sesión de 10 de junio de 1811, p. 1.233 (Oliveros): "La imperfección de nuestras instituciones, y la contrariedad de nuestras leyes son hechos que prueban hasta la evidencia las edades de la sabiduría en el arte de organizar los Estados y darles leyes justas. El Congreso nacional reúne las luces de lo pasado y la experiencia de lo presente: hállase sin trabas en sus decisiones; es depositario de la soberanía del pueblo, y está revestido de ilimitados poderes para hacer su bien, para darla una Constitución, que equilibrando las facultades, lleve la felicidad social a aquel grado de perfección de que son susceptibles las cosas humanas. No sería disculpable si se contentase con menos, si no dedujese y sancionase todas las consecuencias de los grandes principios que ha establecido, sin que por esto se pueda creer que desacredita las determinaciones de sus mayores. He dicho que no fue bien conocido ni consultado en ellas el derecho público. Y no es extraño, cuando el derecho natural, que es su apoyo, si bien fue general su conocimiento en los primeros 
Para los segundos, por el contrario, las Leyes Fundamentales son el marco acerca del que y dentro del cual hay que discutir, sin atreverse bajo ningún concepto a romperlo o perturbarlo: conforman un tesoro que hay que conservar, que hay que proteger y que hay que realizar, coincidiendo en su esencia y en sus contenidos mínimos, pero haciendo hincapié en la necesidad de crear instrumentos que permitan su afianzamiento y su ejecución práctica ${ }^{174}$. Todo ello trufado con invocaciones a la legislación medieval y moderna, a las varias Recopilaciones incluidas las americanas, o a ciertas figuras mitificadas como Alfonso X el Sabio y su obra legislativa, a propósito de temas tan variados como la ciudadanía y la naturaleza ${ }^{175}$, las Cortes $^{176}$, la posición ju-

principios á todos los pueblos, no fue siempre desenvuelto por los hombres en sus consecuencias las más próximas" n 254. Sesión de 12 de junio de 1811, p. 1.247 (Fernández Golfín): "En este día, para siempre memorable, la Nación española, señora de sí misma, dio á Fernando VII el más justo derecho á la Corona; derecho inconcuso, sagrado, más fuerte que el que sus progenitores tuvieron á ella, y que es el único que constituye á un hombre jefe supremo de una nación (...) Si la Nación pudo darse un Rey sin consideración á pactos antecedentes ni á leyes algunas, ¿no podía anular con mayor razón actos que confieren á algunos ciudadanos una autoridad y unos derechos incompatibles con la felicidad de los demás, y destructivos de la igualdad legal que debe unirlos á todos, particularmente cuando no están apoyados en las leyes, ó á lo menos en leyes que sean la expresión de la voluntad general, que es el carácter constitutivo de las verdaderas leyes?"; y nº 272. Sesión de 1 de julio de 1811, p. 1.390 (García Herreros): “Señor, á V. M. no le obliga más ley que la trivialísima de salus populi; las demás las mantendrá en observancia, en cuanto no se opongan á aquella".

${ }^{174}$ Cfr. J. López Alós, Entre el trono y el escaño. El pensamiento reaccionario español frente a la revolución liberal (1808-1823). Madrid, 2011, pp. 241 ss.

${ }^{175}$ Cfr. Constitución en Cortes, ed. cit. Sesión de 4 de septiembre de 1811, pp. 128-132 (Alcocer). P. 4, 12, 2, sobre la naturaleza y los modos de adquirirla; y DSCGE. Tomo III, $\mathrm{n}^{\circ} 337$, p. 1.762-1.764; Sesión de 5 de septiembre de 1811, p. 152 (Salazar); y DSCGE. Tomo III, $\mathrm{n}^{\circ} 338,1.777$, con loas a Alfonso X como sabio y excelente legislador, amén de profundo político, que no sólo exigía servicios anticipados a los extranjeros que querían domiciliarse en sus dominios para ser reputados ciudadanos, sino que antes de todo les concedía fueros y prerrogativas que los igualaban a las clases más elevadas; y Sesión de 6 de septiembre de 1811, p. 170 (Larrazabal); y DSCGE. Tomo III, n $\mathrm{n}^{\circ} 339$, p. 1.788, de nuevo sobre la naturaleza. Acerca de estas cuestiones, que guardan conexión con el status civil, vid. J. Vallejo, "Vida castellana de la muerte civil: en torno a la Ley cuarta de Toro", en Historia, Instituciones, Documentos, n 31 (2004), pp. 671-686; "Indicio liberal de la muerte civil. El Proyecto de Código de 1821 y la definición del sujeto de derechos"; en Derecho, Historia y Universidades. Estudios dedicados a Mariano Peset, ed. cit. Tomo II, pp. 765-775 [= también en Historia Contemporánea, no 33 (2006), pp. 581-603]; y "Paradojas del sujeto", en C. Garriga (coord.), Historia y Constitución, ed. cit., pp. 173-199; y C. Serván, "Los derechos en la Constitución de 1812: de un sujeto aparente, la nación, y otro ausente, el individuo", en AHDE, $\mathrm{n}^{\mathrm{o}} 81, \mathrm{pp} .207-225$.

${ }^{176}$ Cfr. Constitución en Cortes, ed. cit. Sesión de 12 de septiembre de 1811, p. 212 (Borrull), con intención crítica respecto al enfrentamiento de Alfonso X con las Cortes, donde estaba la libertad política frente a los esfuerzos del Rey Sabio y de sus sucesores para adquirir un poder absoluto; y DSCGE. Tomo III, $\mathrm{n}^{\mathrm{o}} 345$, p. 1.820; o Sesión de 13 de octubre de 1811, pp. 535-536 (Sombiela); y DSCGE. Tomo III, $\mathrm{n}^{\mathrm{o}} 376$, p. 2.062, quien sostenía que en las Partidas estaba reconocida la soberanía absoluta en manos del monarca, pero que se modificó "por las del Ordenamiento, pues por ellas se previno, según está expreso en la ley II, tít. VII, lib. VI de la nueva Recopilación, suprimida en la Novísima, que en los asuntos árduos y graves hubiera de convocar el rey á las Córtes, no decidiéndolos sin intervención de éstas". 
rídica de los religiosos a los efectos del sufragio ${ }^{177}$, la calidad de los diputados ${ }^{178}$, el juramento del rey ${ }^{179}$, los requisitos morales de los Secretarios del Despacho ${ }^{180}$, la problemática del fuero eclesiástico ${ }^{181}$, las competencias de los tribunales y las instancias admitidas $^{182}$, o cuestiones atinentes a la reforma constitucional ${ }^{183}$.

Vid. sobre el papel de las Cortes, M. Lorente y J. M. Portillo (dirs.), El momento gaditano. La constitución en el orbe hispánico (1808-1826). Madrid, 2011.

${ }^{177}$ Cfr. Constitución en Cortes, ed. cit. Sesión de 23 de septiembre de 1811, pp. 298-299 (Güereña), con invocación de P. 1, 6, 3 y P. 1, 6, 50; y DSCGE. Tomo III, $\mathrm{n}^{\circ}$ 356, pp. 1.904-1.905. Para estas cuestiones, vid. bibliografía citada supra, nota $\mathrm{n}^{\circ} 175$.

${ }^{178}$ Cfr. Constitución en Cortes, ed. cit. Sesión de 26 de septiembre de 1811, p. 332 (Larrazabal). P. 2, 19, 2; y DSCGE. Tomo III, no 359, p. 1.927.

${ }^{179}$ Cfr. Constitución en Cortes, ed. cit. Sesión de 16 de octubre de 1811, p. 561 (Larrazabal), a propósito del art. 173 constitucional y de unos añadidos rituales, expone que "la sábia legislación de las Partidas dispone que todo juramento se haga en iglesia; y la práctica de muchos reyes católicos acredita el piadoso rito de la comunion"; y DSCGE. Tomo III, n 379, p. 2.095.

${ }^{180}$ Cfr. Constitución en Cortes, ed. cit. Sesión de 23 de octubre de 1811, p. 597 (Güereña): “Deben, pues, ser tales agentes del Gobierno, segun los sentimientos de nuestras leyes de Partida y de Aristóteles, uno de los maestros de la política, por su prudencia, sabiduría y previsión, el ojo de lo futuro, para trasmitir hasta la posteridad la beneficencia de los que imperan"; y DSCGE. Tomo III, nº 386, p. 2.139.

${ }^{181}$ Cfr. Constitución en Cortes, ed. cit. Sesión de 16 de noviembre de 1811, p. 692 (Calatrava), con crítica a la Partida Primera, la cual introduce opiniones y doctrinas ultramontanas, desconocidas hasta entonces en nuestra legislación: una de ésas es precisamente el fuero eclesiástico; y DSCGE. Tomo III, $\mathrm{n}^{\circ} 410$, pp. 2.267-2.268; Sesión de 17 de noviembre de 1811, pp. 703-709 (Villanueva y García Herreros), con cita de la ley 118 del Estilo y de P. 1, 6, 6; y DSCGE. Tomo III, no 411, pp. 2.273-2.276. Para las cuestiones referidas al poder judicial y al orden procesal, íntimamente ligadas, vid. F. Martínez Pérez, Entre confianza y responsabilidad. La justicia en el primer constitucionalismo español (1810-1823). Madrid, 1999; y M. P. Alonso Romero, Orden procesal y garantías entre Antiguo Régimen y constitucionalismo gaditano. Madrid, 2008.

${ }^{182}$ Cfr. Constitución en Cortes, ed. cit. Sesión de 24 de noviembre de 1811, p. 778 (Morales Duárez). P. 3, 4, 9.; y DSCGE. Tomo III, $\mathrm{n}^{\circ} 418$, pp. 2.325-2.326; Sesión de 27 de noviembre de 1811, en DSCGE, $\mathrm{n}^{\circ}$ 421, p. 2.336 (Caneja), afirmando la existencia con base en Partidas de un principio de igualdad; y pp. 2.337-2.338 (Navarrete). P. 3, 16, 35; Sesión de 29 de noviembre de 1811, pp. 792-794 (Villagómez y Luján). P. 3, 23, 25, P. 3, 3, 4 y P. 3, 24, leyes 4 y 6, sobre alzadas o apelaciones; y DSCGE. Tomo III, $\mathrm{n}^{\mathrm{o}}$ 423, pp. 2.347-2.349; Sesión de 30 de noviembre de 1811, p. 802 (Borrull). P. 3, 23, 25 con cita subsiguiente a las Cortes de Briviesca de 1387, de Segovia de 1390, de Madrid de 1502 y a la Novísima Recopilación 11, 21, 2; y DSCGE. Tomo III, no 424, p. 2.354; Sesión de 1 de diciembre de 1811, pp. 809-810 (Gómez Fernández). P. 1, 1, 18, P. 3, 3, 5 y P. 7, 34, Regla 37; y DSCGE. Tomo III, nº 425, pp. 2.3592.360; Sesión de 2 de diciembre de 1811, p. 812 (Dueñas). P. 3, 3, 4 y P. 3, 2, 32; y DSCGE. Tomo III, ${ }^{\circ}$ 426, pp. 2.361-2.362; Sesión de 6 de diciembre de 1811, p. 837 (Aner). P. 3, 22, 13; y DSCGE. Tomo III, $\mathrm{n}^{\mathrm{o}}$ 430, pp. 2.381-2.383; Sesión de 7 de diciembre de 1811, p. 839 (Guridi y Alcocer). P. 3, 24, 1; y DSCGE. Tomo III, $\mathrm{n}^{\circ}$ 431, pp. 2.386-2.387; Sesión de 10 de diciembre de 1811, p. 849 (José Martínez). P. 3, 23, 25; y DSCGE. Tomo III, no 434, p. 2.401; Sesión de 26 de enero de 1812, pp. 1.065-1.068 (Borrull y Gómez Fernández), sobre alzadas que revocan sentencias previas e invocación de P. 3, 23, 25; y DSCGE. Tomo IV, n ${ }^{\circ} 479$, pp. 2.699-2.702; Sesión de 30 de enero de 1812, pp. 1.079-1.080 (Sombiela); y DSCGE. Tomo IV, no 481, p. 2.720; Sesión de 1 de febrero de 1812, pp. 1.088-1.090 (Aner y Dueñas). P. 3, 23, 25 y P. 3, 22, 13; y DSCGE. Tomo IV, nº 482, pp. 2.729-2.731; y Sesión de 3 de febrero de 1812, pp. 1.091-1.093 (Mendiola); y DSCGE. Tomo IV, $\mathrm{n}^{\circ} 483$, pp. 2.735-2.736. Para estas cuestiones, vid. bibliografía citada supra, nota $\mathrm{n}^{\mathrm{o}} 181$. 
Las Partidas con abundancia, excepcionalmente el Fuero Real, y, de forma más esporádica y residual, las Leyes del Estilo, piezas relevantes de la obra jurídica alfonsina toda, comparecen, hablan, enseñan, ilustran, marcan caminos del pasado que no pueden ser alterados, ni modificados, por ser textos esenciales sobre los que no se proyecta, ni se puede proyectar el más mínimo propósito de metamorfosis revolucionaria. Todo lo que ha sido y todo lo que es España ha surgido y ha subsistido a partir de esos textos primarios, los cuales, una vez creados, han devenido fijos e inmutables para la Monarquía, porque constituyen su esencia, su substantia política y jurídica misma, sin la cual el mundo hispánico sería otra cosa diferente y no imaginable, inmarcesible y desconocida. Han surgido en la Historia y lo han hecho para permanecer siempre idénticos a sí mismos porque los principios allí contenidos son universales, racionales, naturales, eternos, hispánicos porque define a la vieja Hispania. Por eso, se citan con respeto y veneración. Por eso, no se tocan, ni se reforman porque hacerlo sería traicionarnos a nosotros mismos y dar pie a la construcción de una realidad diferente y ajena a nuestra esencia. Ésta ha sido captada por tales textos, por tales palabras, por tales conceptos, y no puede, no debe modificarse ni un ápice. En los momentos finales del proceso constitucional, la invocación de las Leyes Fundamentales no cesa un solo instante, como hace Muñoz Torrero, de nuevo diputado quintaesencia del liberal hispánico, pero de formación inequívocamente ilustrada, en la sesión del 17 de enero de 1812, quien pone de relieve las dos tareas que las Cortes han enfrentado y se encuentran ya prestas a concluir: confirmar y asegurar, restaurar y proteger ${ }^{184}$. Oliveros, por su parte, insistía en que nada había cambiado en el proceso constitucional desarrollado, sino que se había operado a partir del pasado y de conformidad con el mismo ${ }^{185}$, y Argüelles, con

${ }^{183}$ Cfr. Constitución en Cortes, ed. cit. Sesión de 17 de enero de 1812, p. 1.001 (Mendiola). P. 1, 1, 7, citadas como las "famosas partidas" (sic), primer texto que habla además de leyes constitucionales "ó que ayuntan á los hombres"; y DSCGE. Tomo IV, n 471, p. 2.647; Sesión de 18 de enero de 1812, p. 1.016 (Guridi y Alcocer): “¿Quantos no se armarían contra ella por esa qualidad [la irrevocabilidad de la Constitución], sin la qual no se opondrían esperanzados a de una reforma futura? Yo creo que las leyes de las Partidas no hubieran sufrido tanta contradicción, si los autores de esta hubiesen concebido que dentro de uno ó dos años se reformarían en la parte que les repugnaba; pero como creyeron que una vez establecidas permanecerían, tomaron por el atajo de arrostrarse al establecimiento. Quisiera evitar á la constitución igual suceso que tal vez apoyarán con haberse formando en ausencia del monarca"; y DSCGE. Tomo IV, $\mathrm{n}^{\mathrm{o}}$ 472, p. 2.656; y Sesión de 20 de enero de 1812, pp. 1.029-1.030 (Argüelles), con referencia a los maestros Roldán y Jacobo; y DSCGE. Tomo IV, $\mathrm{n}^{\circ}$ 474, pp. 2.667-2.668. Para la reforma constitucional, vid. J. Varela Suanzes-Carpegna, La Teoría del Estado en los orígenes del constitucionalismo hispánico (Las Cortes de Cádiz), ed. cit., pp. 303 ss. (= publicado, en $2^{\mathrm{a}}$ edición, con nuevo título: La teoría del Estado en las Cortes de Cádiz. Orígenes del constitucionalismo hispánico. Madrid, 2011, pp. 241 ss.), así como los trabajos, a propósito de la reforma constitucional gaditana, de J. De Esteban, M. Lorente y el propio J. Varela, en J. A. Escudero (dir.), Cortes y Constitución de Cádiz, ed. cit. Tomo III, pp. 413 ss.

${ }^{184}$ Cfr. Constitución en Cortes, ed. cit. Sesión del día 17 de enero de 1812, pp. 1.002-1.005 (Muñoz Torrero). Cfr. DSCGE. Tomo IV, no 471, pp. 2.648-2.649, ya indicada supra.

${ }^{185}$ Cfr. Constitución en Cortes, ed. cit. Sesión del día 20 de enero de 1812, pp. 1.018-1.021 (Oliveros). Cfr. DSCGE. Tomo IV, $\mathrm{n}^{\circ}$ 474, pp. 2.662-2.664. 
su calculada ambigüedad, iba de un lado a otro del espectro ideológico y ahora abrazaba postulados nada favorables a una Nación constituyente ${ }^{186}$. Llegamos, por fin, a la sesión de 18 de marzo de 1812, la previa a la aprobación del texto constitucional, que culmina con un discurso del presidente de las Cortes, Vicente Pascual, en donde éste expone lo que sigue en relación a esa Constitución tan feliz, franca y liberal que forma un magnífico edificio de libertad:

"En unos tiempos, Señor, en que la opresión y tiranía han atropellado escandalosamente los derechos más sagrados del hombre, hasta querer obligarle á sepultar en el olvido su dignidad y lo que fueron sus antepasados. Pero ya en fin un extraordinario, aunque por otra parte desgraciado acontecimiento, ha hecho renacer los siglos de libertad de que gozaron nuestros mayores, y nos ha conducido á los representantes de esta nación heroica á renovar nuestras instituciones antiguas, dándoles el órden, claridad y modificaciones convenientes, y formando sobre ellas la ley fundamental que acaba de leerse, en la qual apenas se encontrará cosa alguna que no se halle consignada en nuestros códigos"187.

Se había conseguido, como lo manifestará el presidente de la Regencia el mismo día de la aprobación definitiva del texto, forjar un documento escrito de enorme relevancia y trascendencia, puesto que conformaba para la Nación el cimiento más sólido de la prosperidad de la monarquía, y más digna de ocupar el corazón de los españoles para su observancia, que del mármol y del cedro para su duración, una obra que era emanación estimable de la sabiduría de V. M., y que formaba la egida impenetrable de su defensa, y el depósito sagrado que encierra las leyes tutelares de su libertad é independencia ${ }^{188}$. Constitución escrita, ordenada, mejorada, simplificada, texto finalmente que sintetizaba o compendiaba las principales Leyes Fundamentales de la Monarquía, que las recuperaba, actualizaba y mejoraba para garantizar su pretensión de eternidad; por todo ello dotado de una superioridad jerárquica incuestionable que lo hacía erigirse en corrector de las restantes normas jurídicas, antiguas y nuevas, y en superior elemento convalidador o reprobador de la acción de cualquier poder público con el reverso de la responsabilidad. Eso era, en definitiva, la Constitución de 1812: una forma nueva para disposiciones antiguas, era la gran Carta de la libertad civil que dejaba asegurados los derechos de la Nación, los del trono y la perpetuidad de la religión y en la exacta observancia de ella está cifrada la felicidad de los españoles de ambos hemisferios ${ }^{189}$. Entre estas disposiciones antiguas y fundamentales, la obra alfonsina ocupaba un lugar privilegiado, como se ha podido ver.

\footnotetext{
${ }^{186}$ Cfr. Constitución en Cortes, ed. cit. Sesión del día 20 de enero de 1812, p. 1.030-.1033 (Argüelles). Cfr. DSCGE. Tomo IV, $\mathrm{n}^{\mathrm{o}}$ 474, pp. 2.666-2.670.

${ }^{187}$ Cfr. Constitución en Cortes, ed. cit. Sesión del día 18 de marzo de 1812, p. 1.117 (Vicente Pascual). Cfr. DSCGE. Tomo IV, $\mathrm{n}^{\circ}$ 524, p. 2.946.

${ }^{188}$ Cfr. Constitución en Cortes, ed. cit. Sesión del día 19 de marzo de 1812, p. 1.121 (Joaquín de Mosquera y Figueroa). Cfr. DSCGE. Tomo IV, nº 525, p. 2.950.

${ }^{189}$ Cfr. Actas de las Sesiones Secretas de las Cortes Generales y Extraordinarias de la Nación Española.
} 
Hasta aquí han llegado los dominios de las Leyes Fundamentales o de rango constitucional, aquéllas que forman la Constitución tradicional, superiores a todas las demás y con querencia a imponerse sobre aquellas otras sin tal calificación. No son todas las que se insertan en la tradición o proceden del Medievo, sino algunas de ellas previamente seleccionadas o decantadas por la experiencia y por la cadencia histórica, aquilatadas por el tiempo y contrastadas en la vida pública. Pero los diputados gaditanos además operan en otro campo más maleable y cambiante. En el ámbito de las Leyes Positivas, según su propia terminología, normas ordinarias, llanas, sin la preeminencia o superioridad de las anteriores, se deja sentir ese efecto doble de la obra alfonsina como modelo, que lo sigue siendo, y asimismo como recipiente normativo sobre el que se puede actuar, aunque con mayor incidencia o profundización en esta segunda dirección aludida. Tomando en cierta forma el modelo de Martinez Marina, las Cortes operan sobre aquellas partes de la obra de Alfonso X que más se han separado del espíritu castellano (el de la verdadera libertad civil y política), que más han traicionado el espíritu hispánico y que más dependen de Derechos ajenos a nuestras grandes tradiciones (generadores de despotismo incontrolado), como especialmente acontece con Partida Primera y Partida Séptima, las que se ocupan de materias eclesiásticas, por un lado, y de los aspectos sustantivos y adjetivos del Derecho criminal (delitos y procedimientos), por otro (menor resistencia suponen Partida Cuarta y Partida Sexta, donde el Derecho romano-canónico ha conseguido transustanciarse en una suerte de razón natural incuestionable y, por ello, no sujeta a revisión). La labor va a ser una suerte de recastellanización, esto es, una vuelta a los orígenes, a la pureza del inicio constitucional, eliminando toda suerte de excrecencia que recuerde a lo extranjero y que haya corrompido lo nacional, por lo que se sigue legislando de cara al pasado y no de cara al futuro en lo que es una tendencia consolidada en estos tiempos, como se expondrá a continuación. La Constitución medieval es el modelo a recuperar y el que hay que volver a poner en funcionamiento. Nada de esto había sucedido en relación a las Leyes Fundamentales, esencialmente derivadas de la Partida Segunda (la más castellana en opinión del canónigo ovetense) y la Partida Tercera (en donde el Derecho romano y el Derecho canónico acababan por triunfar, en tanto en cuanto eran expresión de una razón natural vertida sobre cuestiones procesales, que mejoraba y superaba ampliamente las dinámicas procedimentales del anciano Derecho visigodo y del de los fueros medievales), textos que apenas se revisan o se tocan por todas las razones apuntadas, aunque sí se citen con abundancia. La labor reformista del legislador gaditano está prefigurada en la obra de Martínez Marina y se acomoda a ella, siguiendo un guión intelectual que no debe sorprendernos dado el ascendiente del académico citado sobre los diputados reunidos en la Isla de León y luego en la capital gaditana. El Ensayo, texto histórico y jurídico, había tra-

Madrid, 1874. Sesión de 3 de abril de 1814, pp. 939-940. Carta que, en cumplimiento del Decreto de 2 de Febrero último, dirigió la Regencia al general Copons para presentarla á S. M. 
zado la ruta de cuáles eran la partes reformables y cuáles no la eran, bajo la dirección del Derecho tradicional, esto es, había diseñado el elenco de materias que podían ser reformadas y de aquellas otras que no podían cambiarse, tomando como parámetro de convalidación histórica el que dibujaba el Derecho castellano-leonés, depósito de la libertad primitiva, y no el puro arbitrio descarnado del legislador. La Teoría, texto abierta y mayormente político antes que científico, explicaba cuál y cómo era el instrumento por medio del cual se iban a realizar todos esos cambios previamente proyectados. El primer texto confería ilustración y daba sabiduría; el segundo clarificaba los medios de obrar y amparaba a las Cortes para hacer lo que siempre habían hecho.

Como explicación de ese modo de crear normas, de legislar con la vista puesta en lo pretérito y también en lo futuro, véase, sin ir más lejos el relato histórico que hace Espiga y Gadea en la sesión de 5 de febrero de 1811, a propósito de la elaboración de unos primeros Códigos (civil, criminal, hacendístico, de comercio, y plan de educación o instrucción pública). Nuestra legislación es buena y admirable, es la mejor, pero los tiempos han cambiado y es precisa la reforma en el sentido de adaptación de lo anciano a lo novedoso, no de una drástica remoción de lo ya conocido y de lo ya legislado. Procedemos de Roma, con unas leyes modificadas después por la ferocidad de los visigodos, suevos y vándalos (sangre y superstición), y por el sistema feudal imperante en tiempos medievales (injusto y vicioso), lo cual es de todo punto contrario a los nuevos tiempos, sazonado todo este periplo con pluralidad de textos de redacción impertinente y oscura, por lo que se pide lo siguiente: Examínense, pues nuestros Códigos; sepárense las leyes que no sean conformes á nuestros usos, nuestras costumbres y nuestras circunstancias; modifíquense las que deban sufrir alguna alteración, y si las leyes no son más que la moral aplicada á las diversas circunstancias de los hombres, redúzcanse todas á sus primeros principios; hágase una precisa y clara redacción, y establézcase aquel órden en que siendo una la consecuencia necesaria de la otra, se encuentre el fundamento de su justicia en la resolución de la anterior. Claridad, ordenación, buena redacción, simplificación textual y conceptual, búsqueda de los principios basilares y de lo justo y desarrollo lógico de los mismos, es el marco que debe aplicarse a nuestra legislación, lo que significa que no ha de ser construida de nuevo, sino reformada a partir de lo ya existente y, sobre todo, mejorada desde el punto de vista externo, formal, estético ${ }^{190}$.

En sede eclesiástica, la presencia de esas Partidas combatidas es indiscutible por las razones reformistas aducidas, por ese intento de volver hacia una Iglesia española más cercana a sus orígenes, más pura y virginal si se permite la expresión, sin injerencias regias, prescindiendo de las innovaciones canónicas alfonsinas, derivadas en buena parte del Derecho clásico de los siglos XII y XIII en clara confrontación con los concilios visigodos y del primer Medievo ${ }^{191}$. Pero, sobre todo, aparecen invocadas

${ }^{190}$ Cfr. DSCGE. Tomo I, no 132 . Sesión de 5 de febrero de 1811, pp. 500-501 (Espiga y Gadea).

${ }^{191}$ Cfr. DSCGE. Tomo II, no ${ }^{\circ}$ 194. Sesión de 13 de abril de 1811, p. 861 (Ostolaza). P. 1, 15, 2, sobre pro- 
aquéllas, junto con la restante obra del Rey Sabio, al abordar las cuestiones referidas al proceso y al Derecho criminal, así como a elementos conexos (por ejemplo, cárceles, presos y seguridad de las personas). El debate de un nuevo Reglamento para, entre otras muchas cosas, abreviar pleitos criminales, pone en la brecha a la obra de Alfonso X para acreditar la presencia en sus líneas y palabras de muchas de las ideas e instituciones que se tratan de imponer de nuevo por medio de esa acción legislativa. Se redescubren por parte de las Cortes las disposiciones alfonsinas, olvidadas o arrumbadas, insuflándoles un espíritu de novedad o de modernidad del que carecían en sus inicios medievales, con un esfuerzo adaptativo e interpretativo a los nuevos tiempos que les hacen decir lo que los diputados querían que aquéllas dijesen: lo nuevo se lee con anteojos antiguos y lo antiguo con anteojos nuevos, de modo regular y constante ${ }^{192}$. Así, Argüelles afirmaba que España podía vanagloriarse de tener en sus Códigos vivas todavía, pero no observadas, leyes humanas y llenas de sabiduría, como, por ejemplo, FR. 2, 3, 4 y FR. 2, 8, 3, las cuales nada dejan de envidiar á ninguna legislación del mundo, y son aun superiores á la famosa del Habeas corpus de Inglaterra, pues disponen que ni los acusados de delito capital puedan ser presos dando fiador $^{193}$. Giraldo entendía que el nuevo Reglamento para las causas criminales (el

visión de beneficios eclesiásticos; $\mathrm{n}^{\circ}$ 214. Sesión de 3 de mayo de 1811, p. 1.000 (García Herreros), con cita general a las tres primeras Partidas para recordar la obligación de los obispos de "ir en persona á servir á la guerra, á prestar servicios para ella cuando no puedan ir, y se les obliga á todo lo que toca al bien público del Estado"; y Tomo III, n 328. Sesión de 26 de agosto de 1811, p. 1.694 (José Alonso y López). P. 4, 26, 3, sobre ciertas prestaciones y tributos vasalláticos. Vid. M. Revuelta González, "La Iglesia española ante la crisis del Antiguo Régimen (1808-33)", en Historia de la Iglesia en España. V. La Iglesia en la España contemporánea (1808-1975). Dirigida por Vicente Cárcel Ortí. Madrid, 1979, pp. 3 ss., específicamente, pp. 36-58; E. La Parra López, El primer liberalismo español y la Iglesia. Las Cortes de Cádiz. Prólogo de Antonio Mestre Sanchís. Alicante, 1985, pp. 35 ss.; y M. Morán Ortí, Revolución y reforma religiosa en las Cortes de Cádiz. Madrid, 1994, pp. 13 ss.

${ }^{192}$ Para el contexto de debate de ese Reglamento, que, junto con la abolición del tormento y de los apremios, es lo más relevante que en esta sede se trata en Cádiz antes de la Constitución misma, vid. M. P. Alonso Romero, Orden procesal y garantías, ed. cit., pp. 246 ss. A mayores, para la situación procesal y penal, antes y durante las Cortes gaditanas, vid. C. Álvarez Alonso, “¿Neoclásicos o prerrománticos? La Ilustración penal española entre la barroca prohibición de interpretar las leyes y el principio de legalidad revolucionario", en Quaderni Fiorentini per la Storia del Pensiero Giuridico Moderno, n 36 (2007) [Principio di Legalità e Diritto Penale (Per Mario Sbriccoli)]. Tomo I, pp. 81-130; J. Sainz Guerra, "La Constitución de 1812: de las reformas penales y procesales a la abolición de la tortura" y D. Torres Sanz, "El liberalismo gaditano ante el Derecho Penal", en J. A. Escudero (dir.), Cortes y Constitución de Cádiz, ed. cit. Tomo II, pp. 247-276 y pp. 277-284, respectivamente; y A. Agüero y M. Lorente, "Penal Enlightenment in Spain: from Beccaria's Reception to the first Criminal Code", en Forum Historiae Iuris (Article dated 15. November. 2012) (Dirección en Internet: http://www.forhistiur.de/zitat/1211aguero-lorente.htm).

${ }^{193}$ Cfr. DSCGE. Tomo I, n ${ }^{\text {1 }}$ 145. Sesión de 18 de febrero de 1811, p. 560 (Argüelles). Sigue en la misma línea en $\mathrm{n}^{\circ}$ 207. Sesión de 26 de abril de 1811, p. 944: "El primer cuerpo de leyes que hemos tenido en España despues de restaurada, que merezca la consideración de Código general, es el de las Partidas (...)", a pesar de no ser aprobadas en Cortes, lo que no obsta para reconocer su valor; y pp. 945-946, cuando afirma que Fuero Real y Partidas contienen preceptos que se reiteran en el artículo $1^{\circ}$ del Re- 
Reglamento para la abreviación de las causas criminales es su nombre completo) nada innovaba, nada creaba, nada introducía, sino que todo lo que contenía estaba ya recogido en nuestras viejas leyes, con el ejemplo de P. 7, 29, 1, lo que le llevaba a concluir, para evitar caer en la autocomplacencia y eludir ejercicios de falsa modestia por parte del legislador, que no digamos que vamos á labrar este grande edificio de la libertad civil del ciudadano español, cuando nuestros abuelos lo hicieron ya ${ }^{194}$. P. 7, 9, 1 es invocada por Moragues, con crítica a la labor de los intérpretes por su usual facilidad y osadía: son los responsables del ocultamiento o silenciamiento de esa anciana legislación que ahora vuelve a surgir con la fuerza y protección de las Cortes ${ }^{195}$. El diputado Cañedo, por su parte, entendía que ese nuevo Reglamento y sus preceptos tendrían mucha conformidad con lo establecido en nuestras leyes de Recopilacion y Partida, particularmente en las del título XVI, libro $8^{\circ}$ y $7^{\circ}$; libro II, Recopilacion, $y$ 16, título I, proemio, y 10, título XXIX de la Partida $7^{a}$, en las cuales se funda la práctica criminal en nuestros tribunales, de lo que se concluye que nada de esto se establecería. Y yo creo que la renovación de las leyes, en lugar de dar mayor fuerza á las ya establecidas, antes bien las oscurece y debilita. Si hay abusos contra las leyes, deben corregirse con la vigilancia y el debido castigo. Así, las Partidas deben ser objeto de purificación y de reforma en lo que sea preciso y necesario para acomodarlas a las necesidades y costumbres de la presente época ${ }^{196}$. La línea del debate estará incardinada en estos términos ya citados: no hay nada nuevo bajo el sol, sino que se trata de volver al espíritu de la primigenia legislación con algunos aditamentos destinados a fortalecer la vigencia de las ancianas normas ${ }^{197}$, sin perjuicio de que puedan aparecer contradicciones u oposiciones entre unas y otras, que las Cortes deben resolver caso por caso. Es lo mismo que se ha hecho desde la óptica constitucional ${ }^{198}$.

glamento discutido, pero despreciados y omitidos, por lo que era necesario reactivarlos con mengua del papel de los jueces y magistrados: "He aquí lo que intenta establecer la comisión de Justicia con su reglamento. No nos opongamos á tan saludable medida. Las leyes no quedan derogadas; al contrario, las que protegen nuestra libertad y seguridad adquieren nuevo vigor, presentando su espíritu en breves y claros artículos (...) Así que, Señor, no opongamos esta barrera á las reformas de utilidad tan calificada como lo es la reforma de nuestra legislación criminal".

${ }^{194}$ Cfr. DSCGE. Tomo II, no 206. Sesión de 25 de abril de 1811, pp. 929-930 (Giraldo).

${ }^{195}$ Cfr. DSCGE. Tomo II, n 207. Sesión de 26 de abril de 1811, p. 943 (Moragues).

${ }^{196}$ Cfr. DSCGE. Tomo II, no 208. Sesión de 27 de abril de 1811, p. 957 (Cañedo).

${ }^{197}$ Cfr. DSCGE. Tomo II, no 210. Sesión de 29 de abril de 1811, p. 967 (Giraldo). P. 7, 29, 2; y no 223. Sesión de 12 de mayo de 1811, pp. 1.063-1.064 (Calatrava). P. 7, 1, 16 y P. 7, 29, 4; y p. 1.066 (Gómez Fernández). P. 1, 1, 7 y 9 (sobre el poder del rey para establecer, derogar o enmendar las leyes).

${ }^{198}$ Cfr. DSCGE. Tomo II, no 291. Sesión de 20 de julio de 1811, p. 1.476 (Gómez Fernández): la publicidad en el examen de los testigos en el plenario es opuesta a muchas leyes, como, por ejemplo, P. 3, 16,26 o P. 3, 16, 30. P. 3, 4, 13 habla del secreto judicial. Otro ejemplo se produce, a mayor altura y con mayor relevancia, con ocasión del juramento constitucional en Vizcaya en noviembre de 1812. La Junta General se reúne e instala "según los antiguos fueros", con resultados enfrentados: "Propusieron unos vocales que debía admitirse [la Constitución] con entusiasmo; otros les contradijeron por medios indirectos, y exaltando estos los fueros de Vizcaya, su antigüedad y su excelencia, conmovieron al pueblo 
Un dato que no debe ser soslayado, muestra de esa dependencia del Derecho histórico, de ese necesario conocimiento de lo pretérito para ordenar las tareas legislativas hodiernas: Calatrava pidió se trajesen al Oratorio de San Felipe Neri las Partidas para su lectura inmediata, es decir, para ilustrar y mostrar a los diputados aquellas leyes pasadas, que procedían a revisar o a poner de nuevo a pleno rendimiento, para mejorar la Justicia en todos sus extremos ${ }^{199}$.

Especial predicamento tiene la obra alfonsina cuando se debate la cuestión de los señoríos, su reincorporación -antes que abolición- a los dominios prototípicos de la Corona, un tema importante a los efectos de definir la acción de la Monarquía y sus poderes fácticos, políticos y jurídicos. Alfonso X comparece tanto para poner de relieve que tales señoríos violaban la Constitución tradicional, como para situarnos en el extremo opuesto, es decir, para mostrar que ciertas normas de los mismos cuerpos fundamentales preveían la posibilidad de tales donaciones regias, con uso cumplido de textos visigodos, de Partidas, Fuero Real, Leyes del Estilo, Espéculo y de toda la normativa posterior en la medida en que afectaba o modificaba el cuerpo principal de principios construidos alrededor de ese patrimonio regio. Así permitía ese caudal histórico-jurídico explicar cuestiones tales como las donaciones o las reversiones, sus alcances y sus efectos, en una línea de abierta confrontación que recuerda los primeros compases ilustrados y su empleo de la Historia y del Derecho histórico para apoyar propuestas políticas en provecho de las líneas confrontadas ${ }^{200}$. El texto alfon-

hasta el extremo de sofocar con voces descompuestas las palabras de los vocales que apoyaban la necesidad de admitirla", con el resultado de posponer el reconocimiento del texto constitucional y la posición manifiesta de algunos vocales. Las Cortes ordenan se publique y jure la Constitución sin mayor dilación, restricción o modificación. Cfr. Actas de las Sesiones secretas de las Cortes Generales y Extraordinarias de la Nación Española. Madrid, 1874. Sesión de 16 de noviembre de 1812, p. 753. Sobre estas cuestiones de encaje de la Constitución de Cádiz en el mundo constitucional vasco (el tradicional), vid. B. Clavero, "Constitución en común entre cultura y escritura: encrucijada gaditana de los fueros vascos", en Notitia Vasconiae, $\mathrm{n}^{\mathrm{o}} 2$ (2003), pp.613-661 y pp. 663-694, para el debate posterior; y M. R. Ayerbe Iribar, "Uniformismo jurídico y reacción en el País Vasco", en J. A. Escudero (dir.), Cortes y Constitución de Cádiz, ed. cit. Tomo III, pp. 191-214, con ramificaciones navarras, también constitucionales, estudiadas por M. Galán Lorda, "Uniformismo jurídico y reacción en Navarra”, en ob. cit. Tomo III, pp. 215-231.

${ }^{199}$ Cfr. DSCGE. Tomo II, no 223. Sesión de 12 de mayo de 1811, p. 1-063 (Calatrava). Cosa que a la que era aficionado, como demuestra en $D S C G E, \mathrm{n}^{\circ} 455$. Sesión de 1 de enero de 1812, p. 2.516, a propósito de la discusión del artículo188 de la Constitución sobre la imposibilidad del rey y la Regencia, con lectura de P. 2, 15, 3 .

${ }^{200}$ Cfr. DSCGE. Tomo II, no 243. Sesión de 1 de junio de 1811, p. 1.162 (Alonso y López). P. 5, 4, 9 y P. 4, 26, 3; n 246. Sesión de 4 de junio de 1811, p. 1.182 (Luján). P. 2, 15, 5; nº 249. Sesión de 7 de junio de 1811, p. 1.202 (Villagómez). P. 2, 15, 5, que confirma el "Fuero de España" en orden a no perder, sostener y recobrar los derechos naturales, inherentes e imprescriptibles de la Nación; y P. 5, 4, 9; $\mathrm{n}^{\mathrm{o}} 250$. Sesión de 8 de junio de 1811, p. 1.210 (Caneja). P. 2, 15, 5 y P. 2, 15, 4; nº 251. Sesión de 9 de junio de 1811, pp. 1.222-1.223 (Aparici). P. 4, 26, leyes 1 y 4, sobre cuestiones feudales; P. 5, 8, 28, sobre enfiteusis; y P. 3, 23, 18, sobre jurisdicciones; $\mathrm{n}^{\circ} 252$. Sesión de 10 de junio de 1811, p. 1.231(Guridi y Alcocer), cita como leyes que permiten donaciones de ciertos derechos reales Fuero Juzgo 5, 2, 2, P. 5, 4, 9 y ley 234 del Estilo; y p. 1.237 (Morales Gallego). FR. 1, 5, 1 y FR. 3, 12, 8; nº 253. Sesión 
sino es plenamente maleable: sirve de receptáculo donde caben y desde donde arrancan todas esas lecturas del material pasado, todas esas interpretaciones y revisiones de unos textos vivos y de rabiosa actualidad, pero también para proyectar hacia el presente algunas de sus disposiciones en otras sedes variadas, como cuando Cañedo alega P. 2, 27, leyes 6 y 10, a la hora de premiar acciones heroicas y distinguidas ${ }^{201}$, cuando se invoca la noción de traición $^{202}$, la singularidad americana ${ }^{203} \mathrm{o}$ la oposición de los repartimientos ${ }^{204}$. Se mueven, pues, entre el pasado y el presente, sirviendo a uno y a otro, según quién los alegue o invoque. Todo acababa por depender del intérprete y de los intereses que lo guiasen, pero lo cierto es que no se puede hablar de una ruptura o de una cesura entre los mundos confrontados, entre el mundo del ayer y el mundo del hoy que allí estaban reunidos y no separados, sino, mal que bien, avenidos y forzados a coexistir. No se llega aquí a la radicalidad francesa que acaba por crear Historia a partir de la clara derogación del pasado, que se enfrenta con todas las armas y rudimentos del Derecho a lo pretérito y acaba por pasar por encima de él, por triunfar al derrotarlo sin remisión: aquí, en la Península Ibérica, la Historia seguía instalada entre nosotros y se codeaba con los principios nuevos hasta el punto de intentar su reconocimiento o su inserción dentro de una trayectoria ejemplar. La Historia lo quería todo y quería que todo estuviese en ella, de una u otra forma, para eludir cualquier innovación, sospechosa de cambiar el curso de los acontecimientos y de las esencias eternas.

Tras la aprobación de la Constitución el 19 de marzo de 1812, hay una disminución de las citas, ya genéricas, ya específicas, ya como modelo, ya como auténtica norma jurídica, a Alfonso $\mathrm{X}$ y a sus obras, acaso porque la propia Constitución gaditana había procedido a reorganizar aquellas viejas Leyes Fundamentales y a darles nueva forma a lo largo y ancho de su articulado. Las Leyes Fundamentales tienen ahora un lugar conocido donde están instaladas, escritas y protegidas. Vuelven con fuerza, sin embargo, dentro de sus sedes alfonsinas originarias, en los debates acerca de la Inquisición, máxime si tenemos en cuenta que la supresión de la Santa fue una maniobra

de 11 de junio de 1811, p. 1.241 (Polo). P. 2, 1, 8, P. 2, 15, 5 y Espéculo 2, 16, 4; n² 256. Sesión de 15 de junio de 1811, pp. 1.264-1.265 (Ros). P. 2, 17, 11, P. 2, 1, 2, P. 3, 28, 20, P. 2, 27, 2 y siguientes, P. 4, 25, 3 y P. 4, 25, 1, sobre reversiones; $\mathrm{n}^{\mathrm{o}}$ 264. Sesión de 23 de junio de 1811, p. 1.312-1.314 (Gómez Fernández). P. 7, 10, leyes 14, 15 y 16, P. 5, 4, 9, P. 7, 32, 3, P. 2, 15, 5 y P. 3, 15, 5; y nº 272. Sesión de 1 de julio de 1811, p. 1.391 (García Herreros). P. 3, 11, 28. Para su conexión con las Leyes Fundamentales de la Monarquía, cfr. supra, nota $\mathrm{n}^{\circ} 1743$. El contexto, los debates y las soluciones jurisprudenciales son explicados por S. de Moxó, La disolución del régimen señorial en España. Madrid, 1965, pp. 13 ss.

${ }^{201}$ Cfr. DSCGE. Tomo II, no 302. Sesión de 31 de julio de 1811, p. 1.544 (Cañedo).

${ }^{202}$ Cfr. DSCGE. Tomo IV, no 510. Sesión de 4 de marzo de 1812, p. 2.863 (Gómez Fernández). P. 7, 2, 1, cuya trayectoria posterior se indica a renglón seguido: Ordenamiento de Alcalá de Henares 32, 5; Nueva Recopilación 8, 18, 1; y Novísima Recopilación 12, 7, 1.

${ }^{203}$ Cfr. DSCGE. Tomo IV, no 538. Sesión de 4 de abril de 1812, p. 3.011 (Mejía Lequerica).

${ }^{204}$ Cfr. DSCGE. Tomo IV, no ${ }^{\text {5 }}$ 45. Sesión de 15 de abril de 1812, p. 3.062 (Gómez Fernández). P. 3, 28, 10, con algunas concordancias en la Nueva y en la Novísima Recopilación. 
típica de la concepción del poder legislativo operada por los prohombres gaditanos: se eliminaba la Inquisición, incompatible con la Constitución, pero se reemplazaba por los Tribunales de Fe contemplados en las Partidas, por lo que el recurso a éstas era inevitable y de referencia obligada. Se cambiaba el presente por el pasado: los siglos XV y siguientes dan paso al siglo XIII; se trueca lo que había en ese instante por lo que había mucho tiempo atrás, volviendo a recuperar ese tracto constitucional medieval interrumpido en momentos intermedios ${ }^{205}$. El resultado fue, como se sabe, el Decreto de 22 de febrero de 1813, el número CCXXIII, donde se establecía la supresión de la Inquisición por ser anticonstitucional, recuperando en su plena vigencia $P$. $7,26,2$ y, con esta norma, la capacidad de obispos y vicarios para conocer las causas

${ }^{205}$ Cfr., sobre todo, DSCGE. Tomo VI, indispensable y de inexcusable lectura in toto, pero especialmente el Dictamen de la Comisión de Constitución con el que arranca la Sesión de 8 de diciembre de 1812, pp. 4.191-4.192 (Legislación antigua sobre el castigo de los herejes), con cita de P. 7, 26, leyes 1 a 7. Además, cfr. p. 4.216 (P. 1, 9, 2), p. 4.217 (P. 3, 18, 11), p. 4.271 (P. 7, 26, leyes 1 y 2), p. 4.274 (P. 7, 4, 27), p. 4.364 (P. 7, 26, 2), p. 4.379 (P. 1, 5, 5), pp. 4.382-4.383 (P. 7.26, 2), p. 4.404 (ídem), p. 4.473 (ídem), p. 4.477 (ídem) y p. 4.481 (ídem), a modo de ejemplos evidentes, con citas expresas. Para remisiones ulteriores, cfr. DSCGE. Tomo VII, no 753. Sesión de 23 de enero de 1813, p. 4.587; nº 799. Sesión de 19 de marzo de 1813, p. 4.849: "Para conservar pura, como todos deseamos, la santa religión católica, solamente verdadera, y única de muchos siglos, á esta parte de nuestra Nación, que se ha obligado á protegerla con leyes sábias, ha sido sustituido por los jueces que instituyó el mismo Jesucristo, restituyendo sus derechos imprescriptibles á los Obispos, á quienes puso el Espíritu Santo para gobernar la Iglesia de Dios, restableciendo las leyes de Partida y los antiguos usos conformes á nuestra propia Constitución, tan gloriosamente renovada por V. M., conservando salvo el poder de la Iglesia para juzgar y castigar con penas propias de su poder puramente espiritual los delitos de religión, sin perjuicio de la protección debida siempre por el Soberano, á todos los oprimidos, devolviendo la imposición de los castigos temporales, corporales y pecuniarios á los tribunales privativos, que son los civiles de la Nación, dejando abierto el camino á todos para la acusación de unos delitos que ofende universalmente la delicada piedad de los españoles, y para la justa defensa á los acusados, por los medios legales y conformes á la sábia Constitución política de la Monarquía, removiendo los estorbos que se oponían á la justa libertad y deseados adelantamientos en todo género de literatura, sin omitir las debidas precauciones para que no padezca la menor lesión nuestra creencia en sus divinos dogmas, la moralidad en sus sólidos principios, y la política en sus verdaderos fundamentos; apartando de los clérigos la odiosidad que trae consigo la aplicación de las penas corporales, distinguiendo sabiamente los límites de los dos Poderes supremos, evitando los muchos males que se han experimentado, y recobrando en toda la Europa culta el concepto de ilustración que se nos disputaba, sin perder nada del de sólida religiosidad que tan justamente hemos adquirido". Firman esta exposición Domingo de Santa María, Manuel de Echevarría, Domingo Collazo, Matías Herrero Prieto y José de Ayuso y Navarro; $n^{\circ}$ 851. Sesión de 13 de mayo de 1813, pp. 5.239-5.240 (Jiménez Guazo). P. 2, 13, 25 y P. 4, 18, 7, legitiman la facultad de presentar escritos a la autoridad soberana en negocios arduos "y en que se interesa el bien del Reino, ó el honor ó conciencia de la misma Magestad"; $\mathrm{n}^{\circ}$ 852. Sesión de 14 de mayo de 1813, p. 5.268 (Gordoa). P. 3 5, 20; y DSCGE. Tomo VIII, nº 918. Sesión de 21 de julio de 1813, p. 5.764 (Exposición del Ayuntamiento Constitucional de Mondoñedo): “(...) Y el término de raíz puesto al Tribunal de la Inquisición como incompatible con la Constitución, sustituyéndole los protectores de la fé, conforme á la ley de Partida (...)". Sobre estas cuestiones, vid., por todos, J. A. Escudero, "La abolición de la Inquisición española", en Estudios sobre la Inquisición. Madrid, 2005, pp. 349-438; y, del mismo, "Las Cortes de Cádiz y la supresión de la Inquisición: antecedentes y consecuentes", en J. A. Escudero (dir.), Cortes y Constitución de Cádiz, ed. cit. Tomo II, pp. 285-308. 
de fe, y de los jueces seculares para proceder e imponer penas contra los herejes, siempre de plena conformidad con Constitución y leyes. Es el ejemplo arquetípico que explica, de forma meridiana, el modo de obrar legislativamente hablando de aquellas primeras Cortes que seguían instaladas en ritos, estilos, usos y pautas del Antiguo Régimen, sin que llegase a eclosionar de manera plena y dominante la novedad ${ }^{206}$.

El legislador gaditano no hace tabula rasa del pasado, sino que intenta que el Derecho nuevo se incardine a la perfección dentro de la tradición jurídica que dicen encarnar y respetar para seguir conformando un todo completo con pretensión de exhaustividad y detalle, siempre con la Justicia en el horizonte, como era usual en el Antiguo Régimen, en cuyas coordenadas intelectuales aún nos estamos moviendo. El Derecho nuevo arranca precisamente del caudal jurídico que conforma la vieja tradición nacional, mayoritaria y preponderantemente castellano-leonesa. El Derecho viejo queda encomendado a las Cortes, como sus protectoras, quienes deciden conjugar, ahora sí, los verbos aprobar y derogar leyes, pero también interpretarlas, glosarlas y así desarrollarlas, leyes de todo tipo y factura, de toda temática, ámbito y extensión. Más allá de la órbita tradicional, allí donde el poder ha abierto nuevos ámbitos o nuevos campos, donde no existen precedentes normativos o jurisprudenciales, se asientan los dominios del Derecho nuevo, donde rige sin contestación, ni oposición de ninguna clase, por la superioridad que trae detrás. Los estratos convencionales, tradicionales, usuales, donde el poder se ha movido siempre y ha gestionado sin so-

${ }^{206}$ Decreto CCXXIII de 22 de febrero de 1813, completado con el Decreto CCXXIV, donde se manda leer en las parroquias el decreto anterior, y el manifiesto en que se exponen sus fundamentos y motivos; el Decreto CCXXV, en que se mandan quitar de los parages públicos y destruir las pinturas ó inscripciones de los castigos impuestos por la Inquisición; y el Decreto CCXXVI, por el que se declaran nacionales los bienes que fueron de la Inquisición varias medidas sobre su ocupación, y sobre el sueldo y destino de los individuos de dicho tribunal, todos los cuales llevan fecha de 22 de febrero. Los textos en la Colección de los Decretos y Órdenes que han expedido las Cortes Generales y Extraordinarias. Cádiz, 1813. Tomo III, pp. 199-207. El Manifiesto en que se exponen los motivos del Decreto anterior, del mismo 22 de febrero de 1813, se recoge en DSCGE. Tomo VI, pp. 4.533-4.535: "Siguiendo las Córtes en su firme propósito de renovar en cuanto fuese posible la antigua legislación de España, que la elevó en el órden civil á la mayor grandeza y prosperidad, era consiguiente que hiciesen lo mismo con las leyes protectora de la Santa Iglesia; y dejando atrás los tiempos calamitosos de las arbitrariedades é innovaciones, subieron á la época feliz en que los pueblos y las Iglesias habían gozado de sus libertades y derechos. En la ley de Partida que se cita en el decreto, y en otras del mismo y anterior título, que ya estaban renovadas en la ley fundamental, hallaron las Córtes medios sábios y justos suficientes á conservar en su pureza y esplendor la fé católica, y conformes á la misma religión, á la Constitución é índole de la Monarquía. Desde la época en que la religión comenzó á ser ley del Estado hasta el siglo XV, la Iglesia de España fue protegida por ellas, y todas las demás Iglesias le han confesado la gloria de haber sido la más pura en su fé, la más santa en sus costumbres, y la más bien establecida en todo el orbe cristiano. Claro es, pues, que se halla bien comprobada la eficacia de estas leyes, y que con ellas se logrará en el Reino la conservación de la religión católica, que tan justamente deseáis. Estas leyes dejan expeditas las facultades de los Obispos y sus vicarios para conocer en las causas de fé con arreglo á los sagrados cánones y derecho común, y las de los jueces seculares para declarar é imponer á los hereges las penas que señalan las leyes. En este estado, las Córtes nada han hecho sino restablecer lo que estaba decretado". 
bresaltos sus necesidades y demandas, sin embargo, quedan bajo la égida del Derecho antiguo, ya inmutable, ya modificado a la luz de las nuevas circunstancias. Hay un equilibrio entre ambas dimensiones. Se armonizan, se vuelven compatibles, casuísticamente hablando. Se respeta el viejo Derecho hasta extremos de devoción religiosa, pero ese respeto no paraliza la acción creadora de las Cortes. Como decía Mejía Lequerica, introduciendo en el debate político-jurídico una noción de supremacía constitucional hasta entonces no explicitada de una forma tan clara y rotunda, las leyes han de ser justas y sabias (patrón antiguo), pero además han de ser conformes con la Constitución (patrón moderno, pero, a la vez, antiguo, dado que la Constitución lo era también): Justas eran muchas instituciones que han existido, porque han sido hechas por la ley, y sin embargo se han variado en la forma, salvando su objeto, porque se ha variado el órden civil ${ }^{207}$. Ello era así porque, tal y como afirmaba el diputado Gómez Fernández, las leyes no se derogan o reforman, en todo o en parte, sin justa razón o causa, o por cualesquiera de ellas, para lo cual sirve de apoyo también lo establecido en las Partidas $^{208}$. No hubo así un efecto derogatorio por parte de las Cortes y por parte de la Constitución de tipo absoluto, total, casacional, negador y superador del pasado, constructor del presente y del futuro, sino que se inauguraba una coexistencia compleja donde todos los poderes constitucionales debían ponerse manos a la obra para determinar con exactitud el orden jurídico resultante, suma de lo antiguo y de lo nuevo, yuxtaposición no necesariamente contradictoria de las dos dimensiones temporales opuestas. Así no había, desde la perspectiva jurídica, blancos, ni negros, nítidamente trazados, sino una variada gama de grises, que eran reflejo de la propio indefinición e indeterminación del siglo que se inauguraba. Las venerables Leyes Fundamentales habían dejado paso a una Constitución que las depositaba en su seno y las ordenaba con mejor criterio, al mismo tiempo que dispensaba protección a todas ellas a partir de nuevos y viejos dispositivos. El viejo orden se reformaba, partiendo de sí mismo, para subsistir en el tiempo.

Paulatinamente, el orden constitucional, integrado por Constitución, decretos nuevos y normas antiguas, se consolida, se fortalece y comienza un recorrido que le llevaría a ir separándose cada vez con más intensidad de los viejos preceptos y de las viejas instituciones políticas y administrativas, aquéllas que traían su causa más remota de los cuerpos alfonsinos, con lo que, en consecuencia, el Derecho nuevo se

\footnotetext{
${ }^{207}$ Cfr. DSCGE. Tomo IV, no 550. Sesión de 22 de abril de 1812, p. 3.097 (Mejía Lequerica).

${ }^{208}$ Cfr. DSCGE. Tomo V, n ${ }^{\circ}$ 590. Sesión de 16 de junio de 1812, p. 3.324 (Gómez Fernández), con cita de P. 1, 1, 18 en relación a la modificación de P. 6, 7, 5: "Esta ni ninguna otra se deroga sin justa y evidente causa, ni por cualquiera aunque la mejore en algo; porque como se dice en un capítulo de la distinción 12, ridiculum est, et satis abominabile dedecus, ut traditiones quas antiquitus a patribus suscepimus, infringi patiamur. Y porque para hacer cualquiera derogación ó novedad en la ley constituida es indispensablemente necesario ó que de la constituenda resulte una grande y evidentísima utilidad, ó que la antigua contenga manifiesta iniquidad, y su observancia sea muy nociva; y en una palabra, que estemos en alguno de los casos de que habla la 18, título I, Partida I, de lo cual nos hallamos muy distantes, aun por confesión de la misma comisión de Justicia en su citado dictámen".
} 
fue alejando asimismo del viejo Derecho del Rey Sabio y lo fue posponiendo, al mismo tiempo que lo convertía en un objeto de estudio no desprovisto aún de fuerza normativa. Era el efecto directo de la evolución de los tiempos. Las Leyes Fundamentales y, sobre todo, las Positivas pasan a ser ahora desarrolladas, alteradas, recuperadas, modificadas o postergadas a partir de las decisiones de las Cortes Generales y Extraordinarias, en una dinámica jurídica que se va distanciando, casi de modo imperceptible, de la tradición histórica de la cual se traía causa. Cádiz, en suma, había hecho algo diferente a implantar una Constitución en sentido moderno, a crearla, a gestarla ex nihilo: había reconstituido, como quería Martínez Marina, la libertad de la Nación, y había repuesto y asegurado la Constitución histórica por los siglos de los siglos. La legislación gaditana siguió esas mismas pautas y esos mismos derroteros con la complicación derivada de la necesidad de armonizar lo viejo y lo nuevo, en principio situados en plano de radical igualdad.

6. El tratamiento dispensado por parte del Derecho nuevo al Derecho viejo (la ansiada integración de ambos en un mismo plano jurídico) marca así la suerte de la obra alfonsina en ese futuro inmediato que alcanza hasta la primera mitad del siglo XIX. Es obvio y evidente que el Derecho cambia, que está cambiando y que hay impulsos decididos para que sea de esta forma, pero no lo hace al mismo tiempo la cultura jurídica (experiencias, saberes, disciplinas) que se encuentra en su base y lo subyace. Los conceptos abstractos, las alegorías y los principios han de dejar paso a lo que es una realidad mensurable y auténtica que desborda el margen de una simple lectura teórica de lo que aquí aparece. No hay acompañamiento por parte de aquella cultura que finalmente capta y lee el texto, que lo interpreta y lo hace vivo, que lo aplica, en cuyo contexto se acogen las palabras y los conceptos previos y se les da pleno sentido. Quienes hablaban en las Cortes, hablaban como juristas y hombres públicos formados en el siglo XVIII y comienzos del siglo XIX, no como sujetos contemporáneos. Manejaban, pues, las categorías del momento y las piezas a encajar en un orden jurídico complejo del que partían y que era el que ellos conocían sin plantearse otros modelos alternativos. La forma de disciplinar todo esto era mediante una peculiar y meditada combinación de Derecho y de realidad, es decir, empleando las categorías jurídicas como instrumentos que refrendaban lo que la realidad ofrecía y no al revés, lo que privaba a las normas, a cualquier norma, de la capacidad de cambiar o de influenciar en el sustrato real al que iban a ser aplicadas. Esto llevaba implícito un efecto: hacía a la norma perder su fuerza coactiva y trasladar tal impulso a la realidad circundante, la cual era la que efectivamente hacía el Derecho, lo creaba, lo instalaba con todas sus consecuencias. La derogación o abrogación normativa no implicaba per se el cambio, sino que sucedía al revés: el cambio usaba de la derogación como instrumento para la purificación del sistema en su integridad, lo cual nos sitúa en las antípodas de los órdenes jurídicos modernos, los vinculados al fenómeno codificador, con sus rígidas, estrictas y claras reglas de jerarquía, primacía y prelación. Se procuraba por todos los 
medios, con cierto horror vacui, recuperar y reordenar los diversos fragmentos del cuerpo del Derecho patrio, lo que requería saber cuáles eran las normas vivas y cuáles las normas muertas, y así operar en un sentido conducente a la revivificación o a la resurrección de unas y otras. Ni la Constitución rompe con las Leyes Fundamentales (las presupone y las clasifica de nuevo), ni la actividad legislativa de las Cortes, desarrollo de su ideario político más o menos consensuado, marca una cesura histórica abismal, ni mucho menos. Opera una suerte de derogación virtual de todo el Derecho antiguo, ante el silencio de la Constitución en tales extremos, lo que conduce a un inexorable juego interpretativo posterior por parte de los operadores jurídicos. La nueva norma, formalmente hablando, que condensa el viejo Derecho constitucional o fundamental, debe imponerse a todo lo que ya venía funcionado como Derecho y a todo lo que desde ese preciso instante se aprobase como tal. Operaría, pues, en ambas direcciones, hacia el pasado y hacia el futuro, con la colaboración de un elenco plural de actores. Desde el ciudadano hasta el Tribunal Supremo, pasando por las Diputaciones Provinciales, los Ayuntamientos Constitucionales, la Diputación Permanente y las Cortes mismas, todos están embarcados en la misma singladura, siendo las autoridades, investidas de restos jurisdiccionales, las que se encargaban de dar respuestas cumplidas a estos extremos litigiosos. Las Cortes actuaban como el elemento final del sistema resultante, como cierre del mismo (un poco en el papel que al rey se le reconocía en el Antiguo Régimen como garante final del orden para casos excepcionales y únicos, con intervención esporádica), puesto que eran las que terminaron por determinar el exacto alcance de una Constitución en todos sus recovecos y recorridos, que expresamente no derogaba nada de lo anterior, a partir de todos aquellos conflictos dimanantes de su aplicación, esto es, a partir de las divergencias que la práctica mostraba entre lo que era el Derecho efectivo y lo que tenía que ser el Derecho desde una óptica constitucional. Constitución más leyes nuevas conforman una masa que se lanzaba contra el Derecho antiguo a los efectos de comprobar la resistencia o inmunidad de este último a las novedades introducidas por el legislativo gaditano. Aquello que resistía el embate, podía seguir operando como categoría jurídica; aquello que no soportaba tal desafío, quedaba relegado a su segundo o tercer plano, quedaba apartado de la vida jurídica, aun sin ser aniquilado, ni eliminado en toda su extensión ${ }^{209}$.

Como ha dicho C. Garriga, la legislación gaditana no es más que, formalmente hablando, la explicitación y desarrollo, bajo forma conflictiva y casuística, del efecto derogatorio de la Constitución que no está sancionado de modo expreso en su articulado $^{210}$. No se derogó todo lo anterior en un solo acto legislativo, ni se clausuró el

${ }^{209}$ Sobre estas cuestiones, que nos ubican en una "Edad Media conceptual" antes que en una "Edad Media temporal", que no tiene por qué coincidir en lo cronológico, vid. F. Kern, Derecho y Constitución en la Edad Media. Traducción, notas y estudio introductorio por Faustino Martínez Martínez. Valencia, 2013, pp. 85 ss.

${ }^{210}$ Cfr. C. Garriga, “Constitución política y orden jurídico en España”, cit., pp. 62-73. Como anticipo, del mismo, vid. "Constitución, Ley, Reglamento. El nacimiento de la potestad reglamentaria en España 
mundo del ayer de un plumazo y con contundencia, sino que la derogación tuvo que ser activada y realizada a partir de litigios particulares y concretos, de forma paulatina, y decidida en relación a los mismos sin expresar líneas generales de actuación o de decisión. Aquel bloque constitucional triunfante se irá formando de modo progresivo, dependiendo de los conflictos derivados de su aplicación, con la participación de todos los ciudadanos en cuanto que agentes puestos al servicio de la ideología constitucional, amparados por otras instituciones que tenían como cometido escuchar sus voces y dar curso a sus quejas y demandas, y coordinados, en fin, por unas Cortes que asumían el papel fundamental de armonización de este orden nuevo-viejo por vía interpretativa. Varios principios guiaron este alto cometido que acabó por convertirse en pilar fundamental del orden jurídico en su conjunto: superioridad de la Constitución; búsqueda de la compatibilidad entre ambos tiempos normativos; irretroactividad de las nuevas leyes e indemnizaciones derivadas de la aplicación de la normativa innovadora; asunción del Derecho viejo no derogado (o que no se percibía como inconstitucional) como parte integrante, eventual o temporal, del orden jurídico conjunto resultante. Las Cortes cogen ese Derecho viejo, se sumergen en el mismo, y actúan desde sus interioridades y con arreglo a sus esquemas, dentro y no sobre él, en el mismo y no al margen de aquél, porque no podían, bajo ningún concepto, prescindir de todo lo que suponía y significaba lo pretérito. Las Cortes hacen compatibles tales dimensiones jurídicas, el pasado y el presente, hacen que se den la mano y que se vean forzadas a cohabitar en un mismo hogar. Constitución, decretos de las Cortes y leyes no derogadas integran la tríada normativa del período acotado, de suerte tal que ese Derecho viejo se coloca bajo el amparo del Derecho nuevo y encuentra en las Cortes a su defensor más cualificado. El orden final es un orden historicista, y no podía ser de otra manera, visto lo que hasta aquí se ha visto, pero, a su estilo, lo era también legalista, sólo que la ley que lo caracterizaba era la ley del Antiguo Régimen, la ley del pasado, la ley concebida como mandato de la voluntad del gobernante, tamizada de cierta racionalidad que expresaba la pertenencia a un orden previo, con contenido variable y alcance diverso, una ley que, en realidad, eran muchos tipos de leyes (pragmáticas, cédulas, ordenamientos, cartas, provisiones, etc.). Las Leyes Fundamentales se situaron en el texto constitucional, reducidas ahora a un único cuerpo y sistema, frente a la dispersión y caótica configuración de los momentos anteriores. Como resultas de esto, la cuestión legislativa no fue una sencilla cuestión de poder o de voluntad general, de mero decisionismo político, de hacer leyes así sin más; era una cuestión jurídica, dependiente de la Historia y del Derecho, y, por ende, tenía que ser resuelta en términos jurídicos, usando de una y de otro. Por tales razones, aparece la Historia a los efectos de explicar la legislación, las posibilidades de su reforma y los límites a la misma. El pasado aparecía para recordar a las Cortes de dónde procedía el Derecho y de dónde procedían ellas mismas, y asimismo para mostrar el respeto

(1810-1814, 1820-1823)", en AHDE, nº 65 (1995), pp. 449-531 (= C. Garriga y M. Lorente, Cádiz, 1812. La Constitución jurisdiccional, ed. cit., pp. 169-258). 
reverencial que se debía dispensar a todo ese caudal histórico-jurídico, solamente removido, derogado o eliminado bajo ciertas circunstancias excepcionales. La Historia se convierte en modelo que adoctrina y enseña, pero también en frontera que imposibilita acciones libres y puramente volitivas, es decir, que impide un legislador plenamente moderno que haga lo que le venga en gana. La Historia está ahí para indicar que no todo lo que quiere el legislador vale, sirve, es aceptable, sino sólo aquello que tiene cabida en ella misma, que encaja con su discurso, un discurso sólido, pétreo, monolítico, que podía limarse en algunas de sus aristas, pero no alterarse en su conjunto, ni en su fondo. Si la Constitución recuperaba y aseguraba las viejas Leyes Fundamentales, eliminando todas las derivas despóticas que se habían ido produciendo con el pasar de los años, lo mismo tenían que hacer las Cortes en relación a ese Derecho viejo: aquellas normas que se considerasen como contrarias al espíritu nacional revivido, a esa libertad de la Nación, podían y tenían que ser eliminadas y reemplazadas por otras que mostrasen concordancia con los valores sempiternos. La política legislativa gaditana estuvo orientada en todo momento a restaurar la libertad primigenia, la antigua, la de los antepasados, y a combatir el despotismo, usualmente importación foránea, algo no propio, no hispánico. El escenario de los combates es, de nuevo, el tiempo, la lectura de sus entresijos y el manejo del mismo. Cada golpe asestado a ese Derecho anciano tenía que estar meditado y justificado, tenía que responder a una causa que permitiese pasar por encima de la Historia y presentar unos efectos evidentemente reparadores. El esquema implementado es el que Martínez Marina había esbozado en 1808 en su contemplación de la Constitución gótico-medieval y es el que manejan con soltura y operatividad los diputados doceañistas, como se ha podido ver, de forma arquetípica, en el caso de la Inquisición:

Siglos V-XV. Libertad genuina (nacional, patria), fundada en los orígenes de la Monarquía y de la Nación, con textos jurídicos en donde se han depositado esos valores y esos principios sempiternos (lugar de preeminencia corresponde, ya se ha dicho en varias ocasiones, al corpus alfonsino);

Siglos XVI-XVIII. Despotismo sobrevenido (espurio, extranjero), ligado a influencias extrañas, con una dinámica institucional (las Cortes) y con una producción normativa (mayoritariamente debida al rey y a sus Consejos, secretarios y ministros) que se aleja a pasos agigantados de la tradición;

y, por fin, Siglo XIX. Libertad recuperada o reconstituida. Vuelta a lo nacional y a lo tradicional.

Por tal razón, la política legislativa no puede tener otra razón de ser más que el pasado mismo bajo forma de dualidades (aceptación o rechazo, inclusión o exclusión, es decir la aceptación del viejo Derecho supone de inmediato su inclusión en el nuevo orden jurídico y también al revés: ese orden jurídico nuevo está legitimado por el pa- 
sado constitucional en su conjunto), y esto se justifica porque la misión capital es materializar el esquema anterior, es decir, consagrar esa libertad recuperada o reconstituida, lo que significa tanto como erradicar de una vez para siempre el despotismo. Lo primero implica lo segundo. Si no hay libertad, no hay Nación y no hay Constitución. En consecuencia, el despotismo es el enemigo a combatir con nuevos instrumentos jurídicos para lo cual se pueden traer del pasado soluciones ya ensayadas en otros tiempos, o bien permitir que las Cortes ideen soluciones nuevas que encajen en el molde constitucional (al modo de aquellas precauciones y providencias que fortalecían el edificio de la Constitución: soluciones nuevas, pero que respondían a necesidades antiguas, aquéllas que eran fundamentales). Derivado de toda esta reflexión, en consecuencia, las leyes nuevas no se presentan como algo novedoso, sino como algo que se trae desde el pasado hacia el presente para operar así la recuperación de la libertad primigenia perdida: es, en esas viejas leyes, donde estaba cristalizada la verdadera libertad. De ahí que el Derecho nuevo tenga que compararse siempre con el Derecho viejo, tenga que tenerlo presente como espada de Damocles y como piedra de toque para justificar su existencia, su mera comparecencia, su aparición y su postrer convalidación. Y de ahí que el Derecho nuevo no sea más que simple reposición de antiguos preceptos y que buena parte de la obra legislativa surgida en España entre 1810 y 1814 no sea más que restauración del antiguo y buen Derecho, comenzando por la propia Constitución que era la puesta a punto, a la altura de 1812, de las ancianas y venerables Leyes Fundamentales como explican sus propios redactores.

El discurso historicista, tantas veces citado, tantas veces invocado, tantas veces probado en innumerables testimonios, no fue una broma, un disfraz, una mentira, un disimulo, un subterfugio o una excusa. Estos hombres no mentían porque no tenían tal necesidad de encubrimiento. Todo lo contrario. Fue algo veraz, consciente, deliberado, no reprimido, ni adornado, algo afirmado porque se creía en él, porque se creía en ese pasado y se le tenía presente en todo momento para con lo que se estaba haciendo. Como no hubo posibilidad de articular una verdadera soberanía nacional, ya que no hubo Nación revolucionaria o liberal, y, sin ambas dos, tampoco un verdadero poder constituyente, la Historia fue el único recurso que quedó a los diputados gaditanos como realidad auténticamente constituyente, en cuanto que fundacional, primaria, necesaria u original o, cuando menos, llana y simplemente constitucional. El detonante de todo cuanto se hizo o se intentó hacer fue ese conocimiento histórico. La Historia es el argumento principal que explica, legitima y justifica lo que se está haciendo en el seno de las Cortes: es el verdadero motor del proceso, la fuerza genuina que da pie a la actividad jurídica allí fraguada. La Constitución aparece así (y no podía aparecer de otro modo porque carecía de poder y fuerza para ello) como una reorganización y recuperación de leyes antiguas, no como un texto nuevo obrado por un poder constituyente, incapacitado desde el inicio para desempeñar tales funciones fundacionales. La Leyes Fundamentales, por un lado, se incorporaron a ese texto de nueva forma y factura, pero anciano en cuanto a sus contenidos, de suerte tal que 
apenas sufrieron remociones o refacciones en cuanto a su esencia o espíritu ${ }^{211}$. Las Leyes Positivas, por su parte, actuaron sobre el Derecho viejo de la misma manera, aceptándolo o rechazándolo, en función de su concordancia con ese pasado esplendoroso del que se partía. Las leyes ancianas son adoptadas por el legislador presente en función de su aceptabilidad o no desde la óptica constitucional, desde su concordancia o no con la letra y espíritu de la Constitución. Se buscaba la libertad nacional para asegurarla hasta el final de los tiempos, eludiendo las derivas despóticas recientes y no tanto. La acción normativa se resume en esta dualidad y en este fin. Lo nuevo será reputado constitucional en la medida en que ayude a cumplir ese cometido aludido, en la medida en que coadyuve a la recuperación de la libertad perdida. Por tales razones, no se derogan con carácter genérico todas las leyes, sino sólo las que no sirven a tal propósito. Todo lo que recuerde al despotismo tiene que ser eliminado, depurado, y, finalmente, sustituido o bien por un Derecho absolutamente novedoso (cuyo espíritu o índole evoca ese fin milenario de antaño), o bien por un Derecho antiguo revivificado (que es conducido sin cesuras, ni interrupciones hasta el presente).

En consecuencia, las Cortes no abrogan o derogan libremente, sino en función de ese objetivo y a la vista de los medios de que disponen. No es un proceso mecánico y automático, ni tampoco una acción desarrollada pro futuro, sino un proceso sumamente complejo, reflexionado, meditado, muy pensado, y, sobre todo, volcado o con la vista puesta hacia ese pasado que tanto mandaba aun no siendo ya realidad ontológica, aun careciendo de entidad sustantiva. El legislador aparece en todo momento atado férreamente a lo que el pasado le dicta, sin dispensa y sin remisión posibles. No hay sustitución de un orden jurídico por otro, ni reemplazo incondicionado, ni triunfo de una de las facciones enfrentadas, como enseñará la Modernidad que se hace en los campos donde domina el más acentuado decisionismo voluntarista, rayano en ese absolutismo jurídico, expresión del positivismo llevado a su máxima expresión paroxística (me refiero, claro está, al momento codificador). No hay sitio para la disyuntiva $o$ un orden $u$ otro, sino, al contrario, para la cópula integrativa y acumulativa: un orden y también el otro, al mismo tiempo, juntos, inseparables. Hay convivencia de uno y otro, sin imposiciones, sin claras derogaciones, sin cancelaciones absolutas, completas y progresivas, lo cual no quiere decir que no hubiese conflictos. Los dos órdenes caben y pueden vivir al mismo tiempo, pero eso no implica que la convivencia sea fácil y pacífica. Esas luchas tenían que surgir por la propia lógica del sistema dado que solamente la confrontación podía poner a cada una de las piezas en su ubicación correspondiente y natural. Cádiz, como culminación de un tiempo, el ilustrado, acabó por formar una suerte de orden en apariencia nuevo, mas formado por piezas

\footnotetext{
${ }^{211}$ Así lo proclamaba la Comisión de Constitución en su célebre Discurso Preliminar, ed. cit. [Parte I], p. 77, resaltando la importancia de seguir no el tenor de las citadas Leyes Fundamentales, sino su índole y espíritu, como se había hecho por la misma al elaborar el Proyecto constitucional. Por descontado, las citas a la Partidas o a la Constitución de Castilla están en este documento a la orden del día, como no podía ser de otra forma. Cfr. ob. cit., pp. 68, 72 y 75.
} 
antiguas, venerables, remotas, las cuales se leían y releían a la luz de esa convivencia forzosa a la que estaban llamados imperativamente ambos mundos, el que se iba (y se resistía a hacerlo) y el que quería aparecer (y le costaba enormemente eclosionar). No hubo fractura de época, sino coordinación de tiempos. No hubo ruptura contundente, sino transición larga y calmada. El Derecho nuevo influía y modulaba el Derecho viejo, de la misma manera que el Derecho viejo hacía lo propio en sentido contrario: condicionaba, definía y delimitaba el Derecho nuevo. Tanto montaba el uno como el otro, el primero como el segundo, porque no existía entre ellos ni orden jerarquizado, ni preeminencias, ni prelaciones que valiesen. Ambos eran instrumentos al servicio de un fin más elevado (la libertad recuperada, el despotismo combatido) y a ese fin sacrificaban sus expectativas de supervivencia. Lo que se hizo no se hizo para despistar, ni para tranquilizar a los indecisos, ni para convencerlos, ni para justificar copias francesas, ni para camuflar intenciones revolucionarias o liberales, sino porque se creía en la Historia y en su papel purgador, reparador y fundador. Fue, citando de nuevo a C. Garriga, un orden historicista, efectivamente volcado en la Historia, y desde allí llegó a ser un orden legalista, puesto que en esa Historia se encontró una legalidad anclada en el tiempo, en el pasado esplendoroso de la Monarquía Hispánica, con unas Leyes Fundamentales y unas Leyes Positivas, que tenían que ser toleradas y respetadas, pero mayormente adaptadas a los nuevos tiempos. Por eso, las Partidas y, en menor medida, otros cuerpos alfonsinos, fueron empleados de forma tan natural, común y usual, como tópico general ordinario que encarnaba la Justicia y el Derecho, pero, sobre todo, como cuerpo general donde aparecían reflejadas algunas de esas Leyes Fundamentales con relevancia constitucional, es decir, como compendio o compilación de buena parte de la antigua legislación por la que la Monarquía seguía rigiéndose, quería seguir rigiéndose y, en buena medida, de la que no podía desprenderse ${ }^{212}$. En la Historia y, más en este período convulso, complejo, impreciso y ambiguo, no hay nunca nacimientos, ni ocasos absolutos. Este momento gaditano es un período bisagra en el que, como ha afirmado J. Fernández Sebastián, no hay exactamente dos modelos que se cruzan y se combinan, sino, antes bien, una sucesión de ajustes, deslizamientos, infiltraciones y compromisos, de arreglos provisionales y contingentes, entre diferentes prácticas, conceptos, ideas y representaciones ${ }^{213}$. Como proclamaba en páginas precedentes, no había ni negros, ni blancos, sino

\footnotetext{
${ }^{212}$ Cfr. C. Garriga, “Constitución política y orden jurídico en España”, cit., pp. 75-76.

${ }^{213}$ Cfr. J. Fernández Sebastián, "Política antigua-política moderna. Una perspectiva histórico-conceptual”, en M. V. López-Cordón Cortezo y J.-P. Luis (coords.), La naissance de la politique moderne en Espagne (milieu du XVIII siècle - milieu du XIX ${ }^{e}$ siècle) - El nacimiento de la política modenra en España (mediados del siglo XVIII- mediados del siglo XIX). Mélanges de la Casa de Velázquez. Nouvelle Série, nº 35 - 1. Madrid, 2005, pp. 165 y 178, respectivamente. Vuelve sobre el mismo tema y con idénticas metáforas, en su trabajo "Entre el Espíritu Santo y el espíritu del siglo. Sobre la Constitución de las Cortes y el primer liberalismo hispano", en Anthropos. Cuadernos de Cultura Crítica y Conocimiento, $\mathrm{n}^{\mathrm{o}} 236$ (julio-septiembre, 2012). Constitución de 1812. El nacimiento de la libertad. Número coordinado por Manuel Aragón y Juan José Solozábal, pp. 55-75, lo que lleva a concluir que la Constitución de
} 
tonalidades grises de todas las intensidades imaginables, modulaciones y gradaciones, imprecisiones, porque la combinación de esos tonos era el signo de los tiempos, el espíritu de esos años: los dos momentos o tiempos históricos vivían al unísono, pasado y presente coexistían, iban juntos, y el legislador se veía forzado a actuar de conformidad con las líneas y criterios que le imponía aquel pasado, el medieval y el de tiempos góticos, aun para desplegar efectos en tiempos presentes.

La ya conocida representación del arzobispo de Santiago de Compostela, Rafael Múzquiz, en donde propugnaba como Leyes Fundamentales de la Monarquía Hispánica el carácter estamental de las Cortes, la profesión de fe católica, la consideración de la Iglesia como parte del Estado y la norma que fijaba el orden de sucesión al trono, culminaba con unas palabras que, a mi entender, encarnan lo que todos aquellos diputados de heterogénea formación y profesión, pero con un credo mínimo común, ansiaban en esos momentos de incertidumbre y angustia inaugurados en el mes de marzo de 1808: queremos ser lo que siempre hemos sido. No queremos cambiar ni una fracción, ni un ápice de nosotros mismos, contentos como estamos con este destino eterno que nos ha traído la felicidad y el bienestar. Hemos sido lo que hemos sido y debemos continuar siendo lo que hemos sido. El eterno-retorno jurídico-político era la clave de la salud pública ${ }^{214}$. Todo tenía que cambiar (o aparentar el cambio) para que todo permaneciese igual porque ése era el objetivo final: que nada, ni nadie se moviese. El pecado de la novedad, el miedo a la innovación, que por definición era algo desconocido e imprevisible, la anatematización de todo cuanto introdujese cambios, reformas o revoluciones, eran reemplazados en la mente de nuestros ilustrados por la seguridad, la regularidad, el orden, la constancia, la previsibilidad o la irresistibilidad, garantías todas ellas de la tranquilidad y de la paz. Solamente la Historia podía ofrecer tal variada gama de ventajas, tal catálogo de beneficios. Sin Constitución moderna, racional y normativa, sin ley como epicentro de un nuevo universo político y jurídico que todo lo pudiese y que fuese defendida además frente a todos (especialmente, los jueces y magistrados) a través de las pertinentes medidas nomofilácticas, sin administración personificada del Estado y con pluralidad de autoridades civiles, militares y religiosas, sin verdadero poder judicial, sin auténticos derechos y libertades ciudadanos, sin racionalismo mas o menos mediatizado, sin iusnaturalismo individualista, sin estatalismo, no quedaba más que echarse en los brazos de la His-

1812 es un texto ambivalente, anclado en la tradición, pero con la vista puesta en un nuevo horizonte bilingüe e intersticial, intercontinental intercultural e interepocal, escrito en dos idiomas bastante más conectados de lo que se piensa, el de la tradición y el de la modernidad, que pertenece por derecho propio al Antiguo Régimen y a la Revolución, donde hay ruptura y hay continuidad: "Su auténtico carácter no puede ser aprehendido por aquellos que se complacen en pintar un mundo en blanco y negro, desdeñando los matices, las medias tintas y los tonos intermedios".

${ }^{214}$ Cfr. F. Tomás y Valiente, "El arzobispo de Santiago y las Cortes de 1810", en Homenaje al Profesor Alfonso García-Gallo. Madrid, 1996. Tomo II, volumen 2, pp. 385-435 (=también en Constitución: escritos de introducción histórica. Prólogo de Bartolomé Clavero. Madrid, 1996, pp. 47-98), con la contundente afirmación del prelado gallego, en pp. 413 y 435. 
toria para sostener toda la arquitectura que se quería persistiese el mayor tiempo posible. Y con la Historia, algunos de sus protagonistas y héroes, como un Rey Sabio que había tratado ya en tiempos lejanos, pero, sin embargo, tan cercanos, de enseñar a su pueblo las ventajas del Derecho, de un Derecho que había intentado armonizar lo mejor de la tradición y lo mejor de la innovación, lo popular y lo culto, lo querido y lo pensado. Alfonso X, como el Cid de la leyenda, seguía reinando después de su muerte, por medio de un legado intelectual integrado por varias piezas normativas, que conformaban un autentico segundo cuerpo del rey y, como tal, inmortal ${ }^{215}$. Uno físico, orgánico, se agotó de acuerdo con las inexorables leyes de la vida, y fue fraccionado, siguiendo los dictados de la voluntad regia, entre Murcia y Sevilla. El otro, el relevante, el que tocó la gloria y la perduración, se las procuró asimismo al monarca durante varios siglos hasta que los tiempos modernos, no sin dificultades y complicaciones, sepultaron por siempre y para siempre el Medievo. Pero ese nuevo orden es ya otra Historia que ahora no debe ocuparnos, ni preocuparnos. Mientras tanto, por el peso de ese legado secular, seguíamos moviéndonos en el seno de un orden jurídico plano, sin códigos plenos, sin jerarquías claras, sin normas poderosas, en un almacén de leyes, llamadas españolas, mal difundidas y peor codificadas ${ }^{216}$.

\footnotetext{
${ }^{215}$ Vid. E. H. Kantorowicz, Los dos cuerpos del rey. Un estudio de teología política medieval. Traducción de Susana Aikin Araluce y Rafael Blázquez Godoy. Prólogo de William Chester Jordan. Estudio preliminar de José Manuel Nieto Soria. Madrid, 2012.

${ }^{216}$ Las últimas expresiones las tomo de C. Petit Calvo, "Textos y contextos para una historia de la cultura jurídica europea”, en VV. AA., Cultura jurídica europea: una herencia persistente. Seminario Permanente de Cultura Jurídica (I). Sevilla, 2001, pp. 64-65. Para el orden decimonónico que ahora se vislumbra, aunque tarde en cuajar, vid. M. Lorente Sariñena, La voz del Estado. La publicación de las normas (1810-1889). Madrid, 2001.
} 